UNIVERSIDADE DE SÃO PAULO

FACULDADE DE ECONOMIA, ADMINISTRAÇÃO E CONTABILIDADE DE RIBEIRÃO PRETO

DEPARTAMENTO DE ADMINISTRAÇÃO

PROGRAMA DE PÓS-GRADUAÇÃO EM ADMINISTRAÇÃO DE ORGANIZAÇÕES

MARCELO FRANCISCO NOGUEIRA

Reconhecimento, mensuração e evidenciação do passivo judicial trabalhista

ORIENTADOR: PROF. DR. ALBERTO BORGES MATIAS

Ribeirão Preto

2016 
Prof. Dr. Marco Antonio Zago

Reitor da Universidade de São Paulo

Prof. Dr. Dante Pinheiro Martinelli

Diretor da Faculdade de Economia, Administração e Contabilidade de Ribeirão Preto

Profa. Dra. Sonia Valle Walter Borges de Oliveira

Chefe do Departamento de Administração 
MARCELO FRANCISCO NOGUEIRA

\section{Reconhecimento, mensuração e evidenciação do passivo judicial trabalhista}

Tese apresentada ao Programa de Pós-Graduação em Administração de Organizações da Faculdade de Economia, Administração e Contabilidade de Ribeirão Preto da Universidade de São Paulo, para obtenção do título de Doutor em Ciências. Versão Corrigida. A original encontra-se disponível na FEARP/USP.

Orientador: Prof. Dr. Alberto Borges Matias

Ribeirão Preto 
FICHA CATALOGRÁFICA

Nogueira, Marcelo Francisco

Reconhecimento, mensuração e evidenciação do passivo judicial trabalhista. Ribeirão Preto, 2016. 105 p.: il. ; $30 \mathrm{~cm}$

Tese de doutorado apresentada à Faculdade de Economia, Administração e Contabilidade de Ribeirão Preto da Universidade de São Paulo (FEARP/USP). Área de concentração: Geração de valor

Orientador: Matias, Alberto Borges.

1. Reconhecimento. 2. Mensuração. 3. Evidenciação. 4. Passivo Judicial. 


\section{FOLHA DE APROVAÇÃO}

NOGUEIRA, Marcelo Francisco

Reconhecimento, mensuração e evidenciação do passivo judicial trabalhista

Tese apresentada ao Programa de Pós-Graduação em Administração de Organizações da Faculdade de Economia, Administração e Contabilidade de Ribeirão Preto da Universidade de São Paulo, para obtenção do título de Doutor em Ciências

Aprovado em:

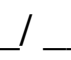

Banca Examinadora

Prof. Dr. Alberto Borges Matias Instituição: Universidade de São Paulo Julgamento: Assinatura:

Profa $^{\text {. Dra }}$. Elionor Farah Jreige Weffort Instituição: Centro Univ. Álvares Penteado Julgamento: Assinatura:

Prof. Dr. Jerônimo Antunes Instituição: Universidade de São Paulo Julgamento: Assinatura:

Prof. Dr. Ivam Ricardo Peleias Instituição: Centro Univ. Álvares Penteado Julgamento: Assinatura:

Prof. Dr. Carlos Alberto Grespan Bonacim Instituição: Universidade de São Paulo Julgamento: Assinatura: 
Dedico este trabalho aos meus pais (Antonio e Vanda), à minha filha (Patrícia) e à Lúcia Carla que, dia a dia, me apoiaram, incentivam a estudar e a buscar a realização de meus sonhos. 


\section{AGRADECIMENTOS}

Muito há a agradecer, ao longo da trajetória percorrida para a finalização desse trabalho.

De um lado, há agradecimentos que tiveram origem acadêmica e que, pelo convívio e pelas orientações recebidas adentraram ao campo pessoal. Incluo, aqui, meu orientador, Prof. Alberto, que, dia a dia, deu mostras de conduta ética, de respeito, de exímia capacidade profissional e de incentivo. Nem sei contar quantas vezes recebi mensagens de confiança e apoio, sintetizadas, rapidamente, em um "Vá em frente!!)".

Outro exemplo que carrego na vida acadêmica é a Profa. Elionor que, nos momentos de dificuldades tem sempre uma palavra amável acompanhada de uma brilhante solução técnica. Professora que aprendi a admirar desde o mestrado e a quem reforço o agradecimento por todas as sugestões e contribuições ao longo de mais essa etapa.

Ao Prof. Jerônimo que, também, desde o mestrado, contribui com o aprimoramento técnico. Suas sugestões nas bancas são valiosíssimas, preciosas diria. Aos Profs. Ivam (com quem tenho o prazer de conviver desde o mestrado) e Bonacim que, com valiosas observações na banca, contribuíra, para o aprimoramento desse trabalho.

Ainda que sem interferência direta nessa tese, deixo meus agradecimentos ao prof. Gilberto Tadeu Shinyashiki que, com aulas valorosas e com talento ímpar, contribuiu em minha formação.

Há, agora, a base de tudo: esse trabalho não teria sido realizado sem o auxílio de minha família, que compreendeu minhas ausências em casa e na MF Perícias e que sempre me incentivou. E, um agradecimento especial (muito, muito especial), para Lúcia e Patrícia, sem as quais, nada disso teria sido feito. 


\section{RESUMO}

NOGUEIRA, M. F. Reconhecimento, mensuração e evidenciação do Passivo Judicial Trabalhista. 2016. 105 f. Tese (Doutorado) - Faculdade de Economia, Administração e Contabilidade da Universidade de São Paulo, Ribeirão Preto, 2016.

A má avaliação do passivo judicial pode impactar de modo negativo as disponibilidades financeiras da organização, com consequencias para sua liquidez e para a continuidade das atividades operacionais. $O$ presente trabalho teve como objetivo verificar se o reconhecimento, a mensuração e a evidenciação do Passivo Judicial Trabalhista atendem aos pressupostos da literatura contábil e do direito natural, no que toca ao conceito de fair value. No contexto metodológico, apresentou-se o arcabouço teórico-jurídico do reconhecimento, da mensuração e da evidenciação. Em seguida, dentre as empresas listadas nos segmentos Nível 1, Nível 2 e Novo Mercado da BM\&FBovespa foram selecionadas, para a amostra, as 40 empresas com maior quantidade de ações em tramitação no TST. Foram analisadas as Notas Explicativas dessas companhias e verificou-se que, a maior parte não divulga informações alusivas à origem do passivo judicial trabalhista, à forma de mensuração das provisões, à quantidade de ações e ao cronograma de desembolsos. Assim, as práticas adotadas por tais empresas não estão em conformidade plena com os pressupostos da literatura contábil e do direito natural pois as determinações contábeis (CPC 25) tem sido observadas em sua forma menos ampla. Também foi constatado que há possibilidade de melhoria no processo de reconhecimento, mensuração e evidenciação eis que há boas práticas, pontuais, nas companhias examinadas que podem ser generalizadas para as demais.

Palavras-chave: Reconhecimento, Mensuração, Evidenciação, Passivo Judicial. 


\begin{abstract}
NOGUEIRA, M. F. Recognition, measurement and disclosure of Judicial Labor Liabilities. 2016. 105 f. Tese (Doutorado) - Faculdade de Economia, Administração e Contabilidade da Universidade de São Paulo, Ribeirão Preto, 2016.

The misjudgment of legal liabilities may impact negatively on the availability of financial organization, with consequences for its liquidity and continuity of operational activities. The present study aimed to verify the recognition, measurement and disclosure of Judicial Labor Liabilities complies with the assumptions of accounting literature and natural law when it comes to the concept of fair value. In the methodological context, it was performed the theoretical and legal framework of recognition, measurement and disclosure. Then, among the companies listed in Level 1, Level 2 and New Market of BM\&F Bovespa, the 40 companies with the largest number of shares in processing in TST were selected for the sample. The explanatory notes of these companies were analyzed and it was found that the most part of them does not disclose information about the origin of the legal liability, the form of measurement of provisions, the amount of shares and the disbursement schedule. Thus, the practices adopted by such companies are not in full compliance with the conditions of accounting literature and natural law because accounting determinations (CPC 25) have been observed in it less wide way. It was also found that there is an opportunity for improvement in the process of recognition, measurement and disclosure once there are good and punctual practices in the examined companies that could be generalized to the others.
\end{abstract}

Keywords: Recognition, Measurement, Disclosure, Legal Liabilities. 


\section{LISTA DE QUADROS}

Quadro 1: Sistematização do processo de análise (parte descritiva e exploratória)

Quadro 2 - Práticas comuns de evidenciação: ausência de detalhamento da origem do passivo judicial 78

Quadro 3 - Práticas diferenciadas de evidenciação: detalhamento da origem do passivo judicial 79

Quadro 4 - Práticas comuns de evidenciação: ausência de detalhamento quanto à forma de constituição das provisões para adimplemento do passivo judicial trabalhista 81

Quadro 5 - Práticas diferenciadas de evidenciação: detalhamento dos critérios utilizados para a constituição das provisões para adimplemento do passivo judicial trabalhista

Quadro 6 - Práticas diferenciadas de evidenciação: detalhamento dos critérios utilizados para a constituição das provisões para adimplemento do passivo judicial trabalhista

Quadro 7 - Práticas diferenciadas de evidenciação: apresentação de cronograma de pagamento do passivo judicial trabalhista. 89 


\section{LISTA DE TABELAS}

Tabela 1 - Tempo médio de tramitação de uma ação trabalhista (media país) ........38

Tabela 2 - Relação de empresas incluídas na amostragem ...............................66

Tabela 3 - Composição e representatividade das provisões ................................70

Tabela 4 - Relações entre a provisão trabalhista e o caixa, o CCL e o

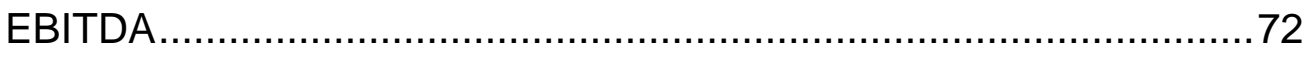




\section{LISTA DE SIGLAS}

CFC - Conselho Federal de Contabilidade

CGJT - Corregedoria Geral da Justiça do Trabalho

CLT - Consolidação das Leis do Trabalho

CPC - Comitê de Pronunciamentos Contábeis

CPC - Código de Processo Civil

CVM - Comissão de Valores Mobiliários

FASB - Financial Accounting Standards Board

IBRACON - Instituto dos Auditores Independentes do Brasil

IFRS - International Financial Reporting Standards

NPC - Norma e Procedimento de Contabilidade

SFAS - Statement of Financial Accounting Standards

STJ - Superior Tribunal de Justiça

TRT - Tribunal Regional do Trabalho

TST - Tribunal Superior do Trabalho 


\section{SUMÁRIO}

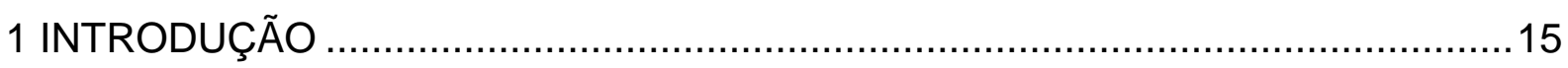

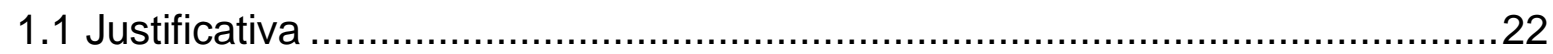

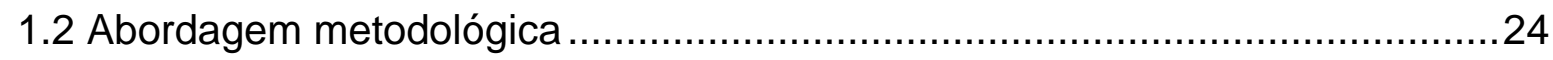

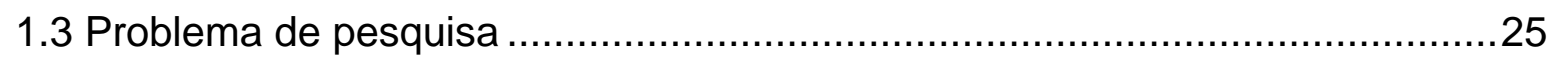



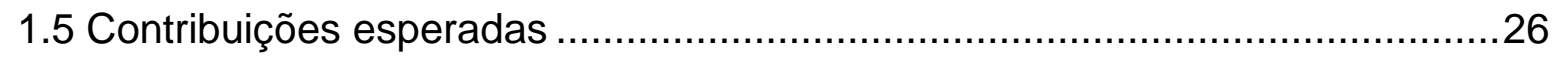

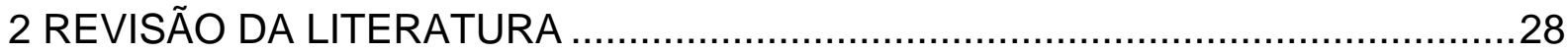

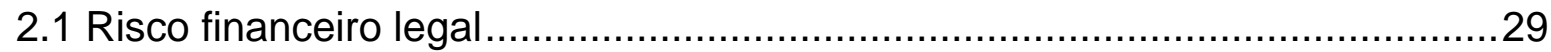

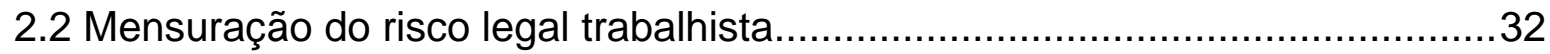

2.2.1 Do tempo de tramitação da ação trabalhista...........................................37

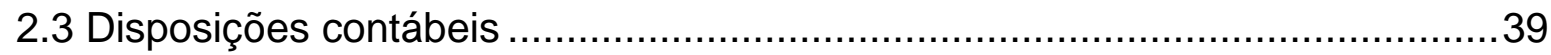

2.3.1 Qualidade da informação contábil .......................................................4

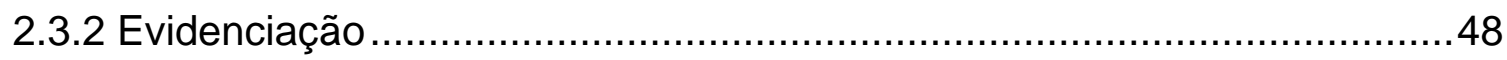

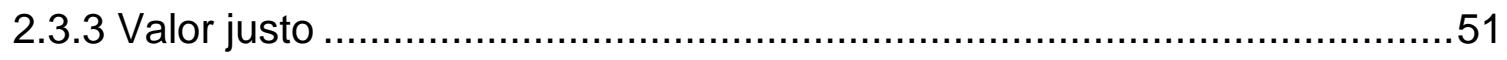

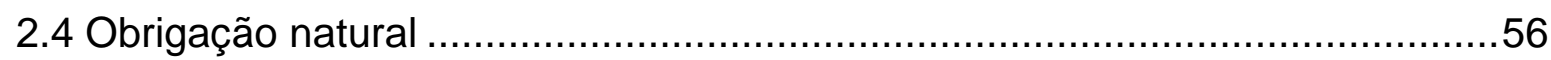

2.5 Formação do conceito de evidenciação do passivo judicial trabalhista alinhado

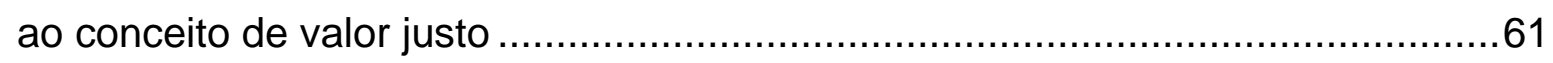



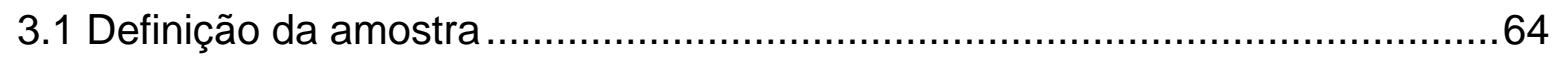

3.2 Técnica para a coleta e análise de dados..................................................67

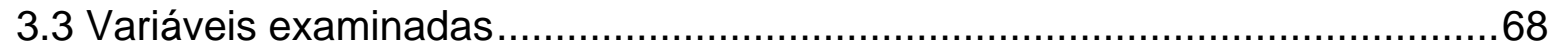

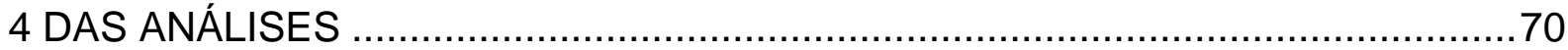

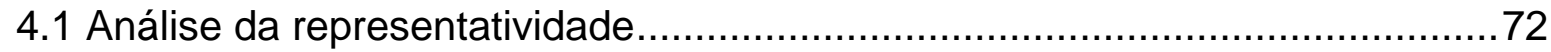




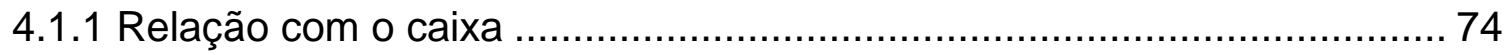

4.1.2 Relação com o Capital Circulante Líquido ......................................... 75

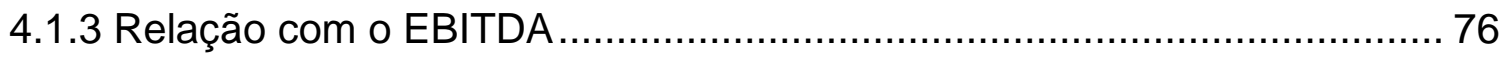

4.2 Análise do reconhecimento e da mensuração ....................................... 76

4.2.1 Da origem do passivo judicial trabalhista................................... 77

4.2.2 Da forma de constituição das provisões ........................................ 80

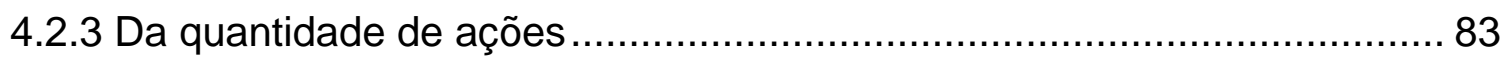

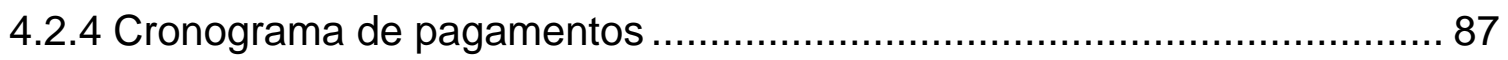

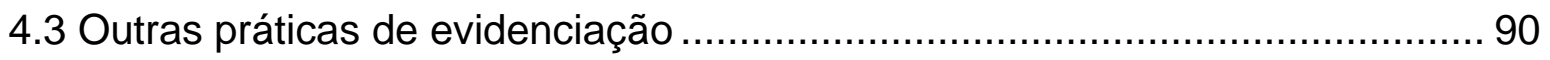

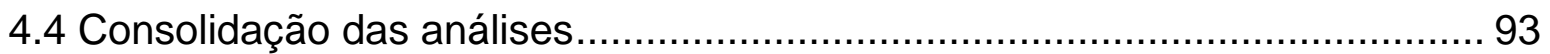

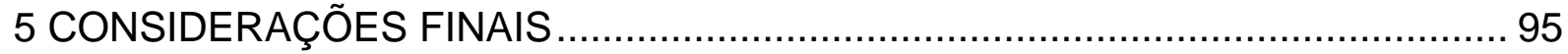

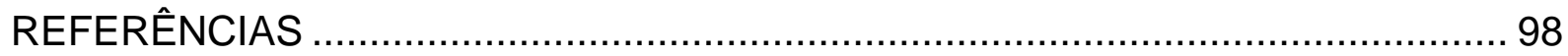




\section{INTRODUÇÃO}

Uma das preocupações da Ciência Contábil é a acurácia dos diversos itens que compõem o patrimônio de uma entidade, sejam eles tangíveis ou não e, para tanto quer em função das disposições do ordenamento jurídico de um determinado país, ou pelas regras emitidas pelos organismos contábeis - ao longo do tempo, os profissionais da área contábil se depararam com mecanismos e ferramentas específicos para a avaliação patrimonial.

Ainda, constitui objetivo da Ciência Contábil prestar informação, útil, tempestiva e relevante ao tomador de decisão. Nesse sentido, Antunes, Antunes e Penteado (2007) mencionam que "a partir da década de 60, devido ao crescimento do mercado de capitais americano, a contabilidade passou a ser vista sob uma perspectiva baseada na informação" e que, "desde então, a contabilidade passou a ser avaliada a partir da sua capacidade de fornecer informações que sejam úteis ao processo de decisório dos usuários".

Ocorre que esse objetivo poderá não ser alcançado se houver negligência, imprecisão ou erro nas informações contábeis transmitidas aos tomadores de decisões, sejam eles internos ou externos à organização.

Um dos fatores que podem impactar o processo de tomada de decisões é o critério aplicado para a valoração dos itens patrimoniais (tangíveis ou não). Essa valoração não é, exatamente, simples posto que a Ciência Contábil, com seu conjunto de ferramentas, busca aproximar-se da realidade, mas, essa disposição, constitui verdadeiro desafio.

Almeida e El Hajj (1997) explicam que "normalmente, os números dão a impressão de exatidão. A exatidão, no entanto, nem sempre é facilmente obtida, quando se trata de Contabilidade, visto que se encontra no campo das Ciências Humanas e não no campo das Ciências Exatas" 
Esse desafio ocorre desde a valoração de um fato contábil isolado até a avaliação do conjunto de elementos patrimoniais de uma determinada organização. As técnicas aplicadas em tais procedimentos passam desde a simples consideração de valores contábeis históricos sem quaisquer ajustes até formas com modelagem matemática e estatística sofisticada.

Independente da forma de apuração tem-se que a discussão quanto à ideia de valor é antiga. Há discussões quanto à natureza do valor objeto de análise, ou seja, de que valor vai se falar: valor contábil, valor financeiro, valor econômico, valor social ou, ainda, daquilo que se denomina como fair value.

Exceção feita ao valor contábil - se for possível entender e aceitar que ele deriva de padrões legais e societários, constantes, uniformes, inflexíveis e indiscutíveis - o que parece utopia - todos os demais conterão elementos subjetivos que nortearão a apuração do valor pelo interesse pessoal ou pelo sentimento de geração futura de riquezas.

Então, mesmo com a adoção de uma técnica única, haverá questionamento em relação ao valor apurado, que poderá ser diferente em relação aos indivíduos A e B, conforme os interesses que cada um tiver na organização. Como exemplo, destacase que o valor de uma determinada entidade é diferente para o seu cliente A e para o seu fornecedor B e, ainda, será, também, distinto para o acionista C.

Essas diferenças, em relação aos valores, não se limitam às avaliações de natureza contábil e, principalmente, não se limitam às demonstrações financeiras que venham a ser publicadas por uma determinada entidade. Assim é que essa questão que nasce contábil tende a ser mais ampla, posto que a discussão de valores envolve todo o conjunto de decisões que uma entidade venha a tomar, seja no ambiente interno (entre suas áreas/departamentos ou entre os seus colaboradores) ou seja no contexto externo (com clientes, fornecedores, governo ou sociedade).

Nesse sentido, em qualquer processo de negociação e tomada de decisão haverá um valor envolvido, seja ele referente a um custo, a uma receita, a algum tipo de 
resultado (inclusive lucro) ou outra métrica qualquer. A questão que se coloca, de plano, é como estabelecer (ou demonstrar) que o valor que se pretende obter em dada transação é justo e que se coaduna com a sustentabilidade financeira da organização sem que isso comprometa sua existência econômica.

Observe-se que, para Xisto (2007, p. 62) "uma empresa é competitiva do ponto de vista financeiro se for capaz de criar valor de forma sustentada". Por outro lado, para Matias (2007) a sustentabilidade está ligada à ideia de geração de valor de forma perene.

A discussão em relação à técnica aplicada no processo de atribuição de valor poderá ser simplificada se houver indicação de qual foi, efetivamente, a técnica utilizada e, bem assim, se houver justificativa para seu uso. Assim, conhecendo o critério poderia ser mais fácil aos tomadores de decisão, concordar (ou não) com o mesmo.

Não basta, por essa linha de raciocínio, que o valor de um item patrimonial (em negociação ou não) seja justo, tal qual indicado no provérbio: à mulher de César não basta ser honesta, deve parecer honesta. É necessário que o valor seja divulgado (no sentido de evidenciação), compreendido e aceito como justo, o que pressupõe que as partes, além de estarem em condição de igualdade na negociação, possuem amplo conhecimento sobre a forma pela qual os valores negociados foram apurados.

Além desse fato outro aspecto deve ser observado: quaisquer modelagens matemáticas, estatísticas ou financeiras, ou mesmo a associação de todas elas levará a um determinado valor, mas, em momento algum, determinarão o preço, eis que esse será regulado pelo mercado, pelos paradigmas e pelas oportunidades concorrentes.

Por conta dessa diferenciação entre preço e valor, pode-se criticar a associação da ideia de valor justo ao preço, ainda que seja o preço de troca em uma condição de absoluta igualdade entre os negociadores, de sorte a refletir as condições atuais do mercado. 
De outra parte, nem todas as transações efetuadas por uma determinada organização terão paradigmas no mercado que possam balizar um preço referencial tido como justo, como sói acontecer como ativos financeiros ou com commodities.

Um exemplo dessa situação de negociação sem paradigma é aquela que visa distribuição de lucros entre os investidores ou entre os colaboradores de uma determinada organização. Busca-se distribuir o máximo de riqueza possível para esses atores e, ao mesmo tempo, a organização buscará manter sua liquidez para que possa investir em suas operações, de modo a gerar resultados positivos cada vez maiores. Afigura-se, pois, um conflito de interesses que, não necessariamente, pode ser resolvido com o uso de prática similar em outras entidades, pelo caráter personalíssimo das mesmas.

A questão, aqui, não se limita aos pressupostos da Teoria da Agência (Jensen e Meckling, 1976), enquanto análise dos conflitos e custos resultantes da separação entre a propriedade e o controle de capital, porquanto, o que se pretende com a elevação do nível de evidenciação e com a indicação de valores justos é a própria diminuição dos conflitos.

Nesses conflitos - que podem comprometer a sustentabilidade financeira de uma organização - haverá um processo de apresentação de contas e resultados que se seguirá de um processo de negociação, estimando-se que o êxito de tal processo possa estar correlacionado com o fato dos envolvidos tomarem os valores em discussão como justos ou não.

Em princípio, qualquer ferramenta de avaliação e mensuração poderia ser aplicada pelo profissional encarregado da avaliação e, inclusive, pelos gestores, mas é importante que se reconheçam as virtudes e as deficiências da ferramenta utilizada para que o destinatário da informação possa decidir conforme sua melhor conveniência. Isso implica em aceitar duas situações: (a) que o critério utilizado para a mensuração/avaliação é compreensível (evidenciação) e que (b) o critério é justo (fair value). 
É nesse ponto que a questão da evidenciação ganha destaque, porque é necessário que os usuários da informação contábil compreendam o procedimento adotado pela entidade no processo de avaliação, mensuração e definição de valor para que, desse modo, possam, adequadamente, usar a informação recebida e, se o caso, questioná-la, solicitando esclarecimentos, complementações ou retificações.

Essa evidenciação, dos procedimentos e critérios adotados pela entidade, sobretudo quando se trata da busca do fair value é importante porque as ideias de justiça e de estipulação de valor justo são amplas, subjetivas e permeadas por " $n$ " variáveis e situações.

Dentre as variáveis estão, a própria questão da assimetria da informação, a questão dos ruídos no processo de comunicação e a questão do aspecto multidimensional da informação, que devem ser tratadas no trabalho técnico de definição de valor, de modo a explicitar se os parâmetros de comparabilidade na busca do valor justo estão, de fato, presentes, em especial, aqueles indicados por Schmidt e Santos (2002), quais sejam: a questão do conhecimento amplo e a disposição das partes envolvidas no negócio em realizar uma transação sem favorecimentos.

Não se trata, pois, de apenas aferir uma condição de mercado, sem favorecimentos a qualquer das partes envolvidas. Trata-se de verificar se as partes envolvidas na negociação detêm amplo conhecimento das informações que permeiam o processo de avaliação e que podem comprometer a busca do valor justo.

E, a evidenciação também é fundamental para que a vantagem do uso do fair value indicada por Lopes (1999), concernente ao aumento significativo no conteúdo informativo das demonstrações financeiras, uma vez que elas passam a conter um número maior de informações e as mesmas estarão a valores mais próximos da visão do mercado - realmente se caracterize.

Uma questão importante é que, nesse processo de evidenciação, o que se busca é qualidade da informação, normalmente, disponível nas notas explicativas e não, 
necessariamente, quantidade. O excesso de informação, inclusive, pode se constituir em problema para o usuário. Preocupação nesse sentido foi externada pelo Comitê de Pronunciamentos Contábeis (2014) que busca maior destaque para as informações relevantes.

Ainda nesse sentido, Nicoletta (2013) - que, dentre outras fontes, apóia-se em pesquisa efetuada por Edilene Santana Santos, da Escola de Administração de Empresas de São Paulo (Eaesp) da Fundação Getúlio Vargas (FGV) e apresentada no X Seminário Internacional CPC Normas Contábeis Internacionais, organizado em São Paulo pela Fundação de Apoio ao Comitê de Pronunciamentos Contábeis (FACPC) - lembra que o volume das notas explicativas tem crescido, porém, com queda na qualidade das informações. Aponta, também, que essa é uma tendência mundial, que os analistas levam muito mais tempo para segregar as informações relevantes e que apenas $16 \%$ das empresas forneceram informações segundo os critérios de transparência estabelecidos pelos órgãos reguladores.

Então, além do problema da qualidade da informação recebida há uma outra questão a ser observada que refere-se ao fato de que a ideia de valor justo (busca e apuração) é mais presente para tratar de ativos do que de passivos. Nesse sentido o Pronunciamento Técnico 46 do Comitê de Pronunciamentos Contábeis - CPC que, em sua estrutura conceitual apresenta uma série de exemplos de mensuração a valor justo, com destaque para os ativos financeiros.

De outra parte, alguns itens do passivo tendem a ser avaliados por profissionais que não são da área financeira, como ocorre com os passivos de natureza judicial, em que a mensuração e estimação dos riscos costuma ser feita por profissionais da área jurídica.

Prestes (2007) mencionou que a análise do risco judicial é aleatória, inclusive no âmbito da Justiça do Trabalho, que possui jurisprudência mais consolidada. Fundamentando tal situação, destaca que: 
Há casos em que os advogados estimaram uma condenação de $\mathrm{R} \$$ 229 mil, mas ao fim da ação a empresa foi absolvida. Uma boa notícia para ela, não fosse o fato de existirem surpresas também no sentido inverso. Em outro caso, enquanto os advogados previram uma condenação de $\mathrm{R} \$ 10$ mil, a Justiça do Trabalho levou a companhia a desembolsar $\mathrm{R} \$ 630$ mil em passivos trabalhistas.

A adjetivação feita por Prestes (2007) não pode, exatamente, ser generalizada eis que, em muitos casos, a avaliação do risco e a mensuração do valor a provisionar não é, de fato, tarefa das mais simples. Necessário que se saiba quais as informações disponíveis naquele momento e como a jurisprudência, por exemplo, pode se alterar ao longo da condução processual. Contudo, não se pode desprezar a possibilidade de ocorrência de erros e de avaliações aleatórias.

Tal situação pode gerar problemas internos na organização e problemas em relação aos usuários externos tendo em vista que os equívocos nas previsões podem gerar comprometimento orçamentário e, sobretudo, no fluxo de caixa da organização, comprometendo, ainda, seus índices de liquidez.

Para a análise de riscos em relação à liquidez é relevante ter conhecimento, no mínimo, em relação à quantidade de ações em andamento, aos métodos utilizados para a resolução das mesmas, ao prazo de duração de tais ações e aos esperados impactos sobre o caixa.

Eventual ausência de tais informações é preocupante porque o crédito trabalhista especificamente na seara judicial - é considerado como especialíssimo, contando com privilégios até sobre os créditos de natureza tributária, mesmo em caso de falência, como menciona Carrion (2006, p.297). De outra parte, como menciona Teixeira Filho (1998, p. 113), a execução trabalhista pode ter início por ato do credor ou do próprio magistrado, imediatamente e sem consulta prévia à parte executada.

Essa execução, nos termos indicados pelo artigo 18 da Consolidação dos Provimentos da Corregedoria Geral da Justiça do Trabalho, deve, preferencialmente, ser feita com o uso da ferramenta eletrônica BACEN JUD que se constitui em um sistema de penhora on line através do qual o magistrado solicita (por meio desse 
convênio com o Banco Central do Brasil) que as instituições financeiras localizem, bloqueiem e transfiram para uma conta à disposição do juízo da execução, valores em contas correntes ou aplicações financeiras, de titularidade do executado para pagamento ou garantia de pagamento da execução.

O uso da ferramenta BACEN JUD é feito sem prévio aviso ao executado e, há relatos de bloqueios múltiplos, ou seja, para uma mesma solicitação judicial, várias instituições financeiras bloqueiam, de modo simultâneo, o mesmo valor em várias contas de titularidade de um mesmo executado, como explicitado pelo próprio Banco Central do Brasil na questão 13 do Manual (Perguntas e Respostas) do Bacen Jud 2.0 .

Caso ocorra uma situação dessa natureza de modo simultâneo à má avaliação do passivo judicial (a menor, por exemplo) as disponibilidades financeiras da organização podem sofrer abalo relevante, obrigando-a a buscar recursos no mercado ou a paralisar projetos, com consequencias para sua liquidez e para a continuidade das atividades operacionais.

Assim, a evidenciação do valor justo do passivo judicial pode contribuir para a melhoria no processo de tomada de decisões dos gestores e, em relação aos stakeholders, pode ser determinante para a decisão de investir ou conceder crédito para uma determinada entidade.

\subsection{Justificativa}

Uma primeira abordagem em relação à ideia de evidenciação é aquela de tornar evidente um fato, demonstrando sua ocorrência e os seus efeitos. Não deveria ser, pois, uma situação estática, posto que tais fatos podem produzir efeitos ao longo do tempo e, em se tratando de uma organização empresarial, há fatos que, uma vez ocorridos, podem indicar resultados favoráveis, neutros ou negativos em relação ao futuro próximo ou mais longínquo. 
Após a cientificação quanto à ocorrência desses fatos e que os mesmos, presumidamente, produzirão efeitos no futuro, cabe à entidade buscar a mensuração dos mesmos, ainda que negativos, de modo justo e transparente

A transparência mencionada está intrinsecamente ligada à questão da evidenciação, dos procedimentos técnicos e dos fatos contábeis, o que implica reconhecer que na busca do valor justo há que se perquirir quanto às características qualitativas e à própria confiabilidade da informação contábil, tal qual mencionado por RiahiBelkaoui (2005).

Cabe, nesse ponto, a lição de Horkeimer (1976) que destaca a necessidade de analisar o ambiente e de estar com a mente aberta para a percepção de novos conteúdos, dentre os quais, podem ser considerados novos tipos de informações nos demonstrativos apresentados pelas organizações.

Informar os stakeholders, de modo adequado e completo, insere-se no campo daquilo que o Direito denomina como obrigação natural, ou seja, algo que deve ser feito independente de disposição contida no direito positivo.

Essa informação, então, não deveria estar sujeita a nenhum tipo de restrição, sobretudo porque, com a aplicação do conceito de valor justo há que se aceitar que os valores e informados pelas organizações tornar-se-ão mais voláteis, sujeitos às oscilações conforme os movimentos do mercado ou conforme mudanças jurídicas de qualquer natureza.

Por fim, tem-se que os destinatários das informações geradas pelas empresas, no mais das vezes, são usuários externos, sem conhecimento prévio de todas as variáveis, o que compromete a qualidade de sua análise, cabendo, à companhia, ofertar o devido suporte - por meio da evidenciação - para que se possa analisar o seu desempenho e os seus resultados ou para que se possa, aferir o valor em negociação e aceitá-lo (se o caso) como justo.

Não há, outrossim, pesquisas anteriores que versem sobre a evidenciação de 
passivo trabalhista judicial e, pelos riscos financeiros envolvidos, acredita-se que o estudo desse tema é relevante para aferir a adequação dos procedimentos adotados pelas companhias e para indicar eventuais pontos de melhoria.

\subsection{Abordagem metodológica}

Por primeiro, apresentar-se-á, revisão da literatura na área de finanças, em especial de curto prazo, para tratar da importância da gestão do capital de giro e de como saídas de caixa sem o devido provisionamento, para quitação de dívidas judiciais podem comprometer a continuidade das operações.

Para tratar da evidenciação do passivo judicial trabalhista e sua interrelação com o conceito de valor justo, esse trabalho apresentará, em seguida, revisão da literatura alusiva às particularidades do processo judicial trabalhista sob o prisma de risco de desembolso financeiro para a parte demandada, conforme a tramitação processual. Nessa etapa, buscar-se-á demonstrar que o risco oscila em conformidade com a tramitação processual e de maneira mais acentuada até que ocorra o trânsito em julgado da ação, ou seja, o momento da tramitação processual em que a decisão de mérito se torna definitiva pela impossibilidade de mudança em função da interposição de recursos.

Passo seguinte a revisão da literatura deixa a esfera jurídica e adentra à seara contábil, para tratar de três questões: (a) as características da informação contábil (b) as melhores práticas a respeito da evidenciação e (c) o conceito contábil de valor justo.

$\mathrm{Na}$ continuação, a revisão da literatura retorna ao campo do Direito para o tratamento do conceito de obrigação natural que será necessário para correlacionar os tópicos anteriores e para a identificar (e apresentar) a existência de um determinado procedimento contábil (no sentido de boa prática e de algo que poderia/deveria ser aplicado pelas organizações quando da divulgação de seus resultados) que esteja alinhado à ideia de valor justo 
Apresentada a revisão da literatura será promovida pesquisa exploratória-descritiva junto às demonstrações financeiras das empresas listadas nos segmentos Nível 1, Nível 2 e Novo Mercado da BM\&FBovespa, de sorte a apresentar, a partir de análise quantitativa e qualitativa, as práticas adotadas por tais organizações quando da divulgação (e evidenciação) de seus riscos legais trabalhistas. Buscar-se-á, também, apresentar os critérios (se explicitados) utilizados pelas empresas analisadas para o reconhecimento e a mensuração de seus riscos legais trabalhistas.

A consolidação dessa análise será efetuada em dimensões construídas a partir da revisão da literatura, albergando as três áreas básicas do estudo: finanças, contabilidade e direito. Essas três dimensões, consideradas, de modo conjunto, apresentam a aplicação do conceito de valor justo na evidenciação do passivo trabalhista judicial.

\subsection{Problema de pesquisa}

O problema de pesquisa que se busca responder nesse trabalho é: à luz do conceito de valor justo, quais são as boas práticas de evidenciação do passivo judicial trabalhista?

\subsection{Objetivos}

Constitui objetivo geral desse trabalho identificar, através do conteúdo das notas explicativas das demonstrações financeiras de empresas brasileiras de capital aberto, se essas divulgações "estão em conformidade com os pressupostos do conceito de fair value.

Em relação aos objetivos específicos, o trabalho irá: 
- explicitar as oscilações no valor do risco de desembolso em uma ação trabalhista;

- apresentar boas práticas de evidenciação do passivo judicial trabalhista à luz da literatura contábil;

- correlacionar as boas práticas contábeis de evidenciação com os preceitos jurídicos da obrigação natural;

- analisar as demonstrações financeiras das empresas listadas nos segmentos Nível 1, Nível 2 e Novo Mercado da BM\&FBOVESPA, no que pertine ao reconhecimento, mensuração e evidenciação do passivo judicial trabalhista;

- descrever as formas utilizadas pelas empresas analisadas para evidenciar os valores de seus passivos judiciais trabalhistas.

\subsection{Contribuições esperadas}

Espera-se que o trabalho possa identificar deficiências no processo de evidenciação e mensuração dos fatos contábeis, dentro do conceito de valor justo, e, bem assim, contribuir no apontamento de melhorias no processo de evidenciação das informações contábeis, por parte das organizações, em relação aos seus passivos de natureza judicial.

Com a melhoria do processo de reconhecimento, mensuração e evidenciação, por parte das organizações, acredita-se que poderá haver maior aproximação dos conceitos (contábil e jurídico) de valor justo e que, com isso, os aspectos concernentes à relevância e confiabilidade da informação contábil sejam melhor compreendidos pelos usuários das informações contábeis, sociais e financeiras, elevando, então, o grau de sustentabilidade financeira. 
Informações mais completas e mais próximas da realidade (valor justo e direito natural) podem contribuir para a melhoria do processo de gestão de pessoas (mitigação do risco de ações trabalhistas) e do processo de gestão do passivo judicial.

Assim se espera porque a análise deixa de ser pontual (valor provisionado) e passa a ser mais ampla, desde a origem do passivo (o que lhe deu causa), passando pelos critérios de mensuração, com indicação de outros aspectos tais como a quantidade de ações e o esperado fluxo de desembolsos. Então, não se analisará mais, apenas um valor estanque, mas sim, o risco como um todo.

Por fim, espera-se que as diretrizes estabelecidas nesse trabalho possam constituir procedimento habitual para a evidenciação do passivo judicial trabalhista. 


\section{REVISÃO DA LITERATURA}

$\mathrm{Na}$ introdução a esse trabalho destacou-se que as notas explicativas das demonstrações financeiras tem se mostrado mais amplas, porém, com menor qualidade informacional relevante e que isso é uma característica mundial.

Qualquer processo de análise deve ser contextualizado, e, no que concerne à análise financeira, isso não é diferente, cabendo ao analista cotejar as informações contábeis e financeiras com o ambiente externo, especialmente em relação aos cenários econômico, financeiro, social, político e legal.

É, então, dessa forma que as demonstrações financeiras devem ser analisadas e somente após o momento em que se possa atestar sua fidedignidade. E isso (análise a partir de dados representativos e de forma contextualizada) é característico, também, de outros ramos do conhecimento, como a infometria, por exemplo, onde Santin (2011), concluiu que:

As diversas abordagens da infometria podem contribuir em larga escala para que se tenha uma visão global das estruturas do conhecimento e dos conjuntos sociais que promovem sua comunicação, de forma a possibilitar o acompanhamento e a avaliação dos fenômenos relacionados à informação. Contudo, sua utilidade é válida para complementação e não substituição da avaliação qualitativa, estando sua validade e confiabilidade condicionada à representatividade dos dados e à contextualização.

A questão que será discutida aqui, nesse trabalho e no presente referencial é como as companhias evidenciam seu passivo judicial trabalhista (incluindo 0 reconhecimento e a mensuração) e, se há evidências de que as informações disponibilizadas permitem aferir se tais procedimentos são adequados às mutações, aqui entendidas como as variações no risco de desembolso financeiro ao longo da tramitação processual advindas da própria tramitação de uma ação judicial (ou de um conjunto de ações, situação em que é necessário monitorar o risco de cada ação judicial e o seu respectivo impacto financeiro no fluxo de caixa da organização). 
Há, aqui, inter-relações entre a contabilidade, finanças e o direito, sendo que a cada movimentação jurídica haverá alteração no risco de desembolso financeiro, o que deve ser objeto de reconhecimento e de tratamento contábil.

Para avaliar essa relação entre os eventos e suas inter-relações, o profissional contábil deverá, seguindo a lição de Dantas, Zendersky e Niyama (2004), buscar junto à entidade, as informações qualitativas e quantitativas que possibilitem aos usuários formar uma compreensão das atividades desenvolvidas e dos seus riscos, cumprindo aspectos de tempestividade, detalhamento e relevância indispensáveis.

Na seqüência, apresentar-se-á a revisão da literatura a respeito dos seguintes pontos estruturais desse trabalho:

- riscos financeiros legais;

- mensuração do risco legal trabalhista;

- qualidade da informação contábil; evidenciação e valor justo;

- obrigação natural.

Ao final desse item, esses pontos estruturais serão reunidos de modo a indicar as práticas de evidenciação alinhadas à ideia de fair value e, bem assim, para explicitar as dimensões de estudo.

\subsection{Risco financeiro legal}

O termo risco, genericamente é utilizado quando se quer tratar dos efeitos de ocorrência de um evento futuro (que deve ser aleatório e independente da vontade humana). Nesse sentido, busca-se o produto da combinação de duas variáveis: (a) a probabilidade da ocorrência desse evento e (b) os efeitos que o evento produzirá caso ocorra.

Bernstein (1997, p. 21) trata o gestor como um indivíduo que deve ter alguma capacidade preditiva (não no sentido de clarividência, mas sim do sentido de tentar 
antecipar os efeitos futuros mediante processo analítico racional) e que, por isso, para mitigar o risco, deve ter acesso à informação. E, continua (p. 69) mencionando que a palavra risco está associada à tomada de decisão e ao verbo "ousar" que é o significado da palavra "riscu" (ou "risicu"), em latim.

Mais adiante, Bernstein (1997, p. 110) menciona que:

"Os fatos não são os mesmos para todos. Pessoas diferentes dispõem de informações diferentes; cada um de nós tende a matizar a informações de que dispõe a sua própria maneira. Mesmo o mais racional dentre nós muitas vezes discordará sobre o significado dos fatos"

Nesse ponto, materializa-se o problema da informação e que merece o cuidado da evidenciação, tanto para os usuários internos quanto para os externos. Assim, a primeira questão é que, para decidir (para tomar decisão) é necessário ter acesso à informação, mas não a qualquer informação, é necessário ter acesso à informação tempestiva, relevante e, especialmente, confiável.

Quando se trata de risco legal, a parametrização de modo objetivo é mais complexa porque a ciência jurídica não é exata. No Brasil, em especial ${ }^{1}$, há divergências jurisprudenciais relevantes ${ }^{2}$ e, esse aspecto, inclusive, é um dos pressupostos de admissibilidade de recursos para a terceira instância ${ }^{3}$ processual brasileira, como consignado no artigo $102^{4}$ da Constituição Federal.

1 Mas essa não é uma particularidade brasileira. No Direito Romano os pretores mudavam a aplicação da lei mediante alteração nos julgados, acompanhando a evolução da sociedade e de seus costumes.

2 Para tentar minimizar esse efeito a Emenda Constitucional 45 criou a Sumula Vinculante cuja finalidade é diminuir a litiogisidade mediante coerção aos juízes de todos os tribunais a seguirem o entendimento adotado pelo Supremo Tribunal Federal (STF) sobre determinado assunto com jurisprudência consolidada. A questão é que, tratando-se de ação trabalhista, são diminutos os casos que comportam recurso ao STF.

${ }^{3}$ No caso do processo judicial civil a terceira instância é o STJ - Superior Tribunal de Justiça e, no caso de ações trabalhistas a terceira instância é o TST - Tribunal Superior do Trabalho, ambos sediados em Brasília/DF.

4 Quando a decisão recorrida "der a lei federal interpretação divergente da que lhe haja atribuído outro tribunal" (art. 102, III, c, da CF/88) 
Então, o próprio sistema jurídico processual admite que suas decisões não são (e não necessariamente serão) uniformes e, portanto, mesmo que alguém (ou alguma organização) busque as melhores práticas no sentido de observar a legislação, ainda assim poderá ter ações ajuizadas contra si.

É, então, esse risco de desembolsos financeiros motivados por conta de transações inadequadas, demandas judiciais (pelo trato com empregados, colaboradores, clientes, fornecedores, concorrentes e governo), mudanças na lei, falha na cobrança de garantias e interpretações legais que se chama de risco legal.

Matias (2007, p. 24) tratando do risco legal explicita que tais riscos englobam contratos falhos mal redigidos, incompletos ou que não possuem amparo legal.

Relevante ponto de impacto na questão do risco legal diz respeito ao valor provisionado (ou que deveria ter sido provisionado) para fazer frente a essa possível obrigação, porque esse ato produz reflexo direto no fluxo de caixa e no capital de giro da organização e, portanto, a estimativa do valor deve manter-se o mais próximo possível do efetivo valor a ser desembolsado e do momento em que essa saída de caixa for requerida.

Erros na etapa supra podem trazer consequencias prejudiciais para as organizações. É que, lançar valor a maior pode gerar comprometimento imediato do caixa por conta de perda de liquidez e pelo não aproveitamento de oportunidades de investimento e, ao contrário, o lançamento de valor a menor pode gerar uma situação de risco para a entidade quando do desembolso que pode não estar, devidamente garantido ${ }^{5}$.

E, esse problema - que se materializa no fluxo de caixa - pode levar uma empresa à quebra, como menciona Goldratt e Cox (1990, p. 45). Importante, pois, a gestão do ativo circulante, como ensina Matias (2007) para que seja mantida a quantidade

\footnotetext{
${ }^{5}$ Nessa situação haveria uma saída de caixa não programada (provisionada) o que comprometeria a execução orçamentária e o capital de giro.
} 
suficiente de caixa para sustentar a atividade operacional da empresa e atender às necessidades especiais de caixa, onde, por óbvio, encontram-se os desembolsos por conta dos passivos judiciais.

\subsection{Mensuração do risco legal trabalhista}

Uma das facetas do risco legal é a trabalhista e que se refere à possibilidade da organização ser demandada por empregados, ex-empregados, colaboradores e prestadores de serviço ${ }^{6}$, em ações que envolvam matérias relacionadas às questões trabalhistas.

No ambiente judicial esse risco está associado às ações que tramitam na Justiça do Trabalho, cuja competência está preconizada no artigo 114 da Constituição Federal (com a redação dada pela Emenda Constitucional 45). In verbis:

Art. 114. Compete à Justiça do Trabalho processar e julgar:

I as ações oriundas da relação de trabalho, abrangidos os entes de direito público externo e da administração pública direta e indireta da União, dos Estados, do Distrito Federal e dos Municípios;

II as ações que envolvam exercício do direito de greve;

III as ações sobre representação sindical, entre sindicatos, entre sindicatos e trabalhadores, e entre sindicatos e empregadores;

IV os mandados de segurança, habeas corpus e habeas data, quando o ato questionado envolver matéria sujeita à sua jurisdição;

$\checkmark$ os conflitos de competência entre órgãos com jurisdição trabalhista, ressalvado o disposto no art. 102, I, o ;

VI as ações de indenização por dano moral ou patrimonial, decorrentes da relação de trabalho;

VII as ações relativas às penalidades administrativas impostas aos empregadores pelos órgãos de fiscalização das relações de trabalho; VIII a execução, de ofício, das contribuições sociais previstas no art. 195, I, a , e II, e seus acréscimos legais, decorrentes das sentenças que proferir;

IX outras controvérsias decorrentes da relação de trabalho, na forma da lei.

As ações trabalhistas possuem regras de tramitação específicas, definidas pela

${ }^{6}$ Há possibilidade de ser demandado na qualidade de tomador do serviço, com riscos de responsabilização solidária ou subsidiária, em casos de contratação com cooperativas ou nos casos de terceirização. 
Consolidação das Leis do Trabalho sendo que o Código de Processo Civil é utilizado de modo subsidiário.

Uma das particularidades da ação trabalhista é o momento em que a parte demandada pode apresentar sua defesa. Esse prazo vem definido nos artigos 844 a 847 da CLT, nos seguintes termos:

Art. 844 - O não-comparecimento do reclamante à audiência importa o arquivamento da reclamação, e o não-comparecimento do reclamado importa revelia, além de confissão quanto à matéria de fato.

Parágrafo único - Ocorrendo, entretanto, motivo relevante, poderá o presidente suspender o julgamento, designando nova audiência.

Art. 845 - O reclamante e o reclamado comparecerão à audiência acompanhados das suas testemunhas, apresentando, nessa ocasião, as demais provas.

Art. 846 - Aberta a audiência, o juiz ou presidente proporá a conciliação. (Redação dada pela Lei no 9.022, de 5.4.1995)

$\S 1^{\circ}$ - Se houver acordo lavrar-se-á termo, assinado pelo presidente e pelos litigantes, consignando-se o prazo e demais condições para seu cumprimento. (Incluído pela Lei $\mathrm{n}^{\circ}$ 9.022, de 5.4.1995)

$\S 2^{\circ}$ - Entre as condições a que se refere o parágrafo anterior, poderá ser estabelecida a de ficar a parte que não cumprir o acordo obrigada a satisfazer integralmente o pedido ou pagar uma indenização convencionada, sem prejuízo do cumprimento do acordo. (Incluído pela Lei no 9.022, de 5.4.1995)

Art. 847 - Não havendo acordo, o reclamado terá vinte minutos para aduzir sua defesa, após a leitura da reclamação, quando esta não for dispensada por ambas as partes

Então, a primeira constatação, a teor do referido dispositivo legal é que o não comparecimento à audiência inicial, deixando de apresentar a defesa em tal ocasião é um evento muito prejudicial ao demandado porque implica, diretamente, na aplicação da pena de revelia e na confissão quanto às matérias de fato ${ }^{7}$.

Para compreensão desse risco, considere-se, aqui, como exemplo, que o indivíduo A, na qualidade de ex-empregado da Cia. B, ajuíza ação trabalhista contra sua ex-

\footnotetext{
${ }^{7}$ Conforme artigo 844 da CLT.
} 
empregadora postulando o recebimento de 1.000 horas extras, no valor de $\mathrm{R} \$$ $40.000,00$. Fundamenta, mencionando que recebia salário hora de $R \$ 20,00$ e que o adicional de horas extras era de $100 \%^{8}$. Não há prescrição a ser computada.

No momento em ocorre a citação ${ }^{9}$ da companhia demandada o seu risco legal trabalhista corresponde a $\mathrm{R} \$ 40.000,00$ que é o valor postulado na demanda.

Caso a companhia demandada compareça na audiência inicial e apresente sua defesa, acompanhada de elementos documentais robustos que mostrem, por exemplo, que o salário hora do autor não era de $R \$ 20,00$, mas sim de $R \$ 10,00$ e que o adicional de horas extras deveria corresponder a 50,00\% (ao invés de 100\%), há fundamento para uma nova apuração do valor do risco legal trabalhista que, agora, passa a corresponder a $\mathrm{R} \$ 15.000,00^{10}$.

Então, nesse exemplo, o risco legal trabalhista, no momento da citação da ré era de $R \$ 40.000,00$ e passou para $R \$ 15.000,00$ quando da apresentação da defesa e de prova documental na audiência inicial.

Independe, aqui, a posição de especialistas no sentido de que, ao final, o pedido de horas extras poderia ser julgado improcedente, tendo em vista que, nesse momento, da audiência inicial, o risco ainda é de $\mathrm{R} \$ 15.000,00$.

Conforme o restante das provas produzidas (juntada de cartões de ponto, depoimento pessoal, oitiva de testemunhas ou perícia contábil) esse valor de risco poderia ser reduzido e, então, o provisionamento comportaria novo ajuste.

${ }^{8}$ Para obtenção do valor de $\mathrm{R} \$ 40.000,00$ realizou-se o seguinte cálculo: 1.000 horas extras * $R \$$ 20,00 por hora $\times 2,00$ (aplicação do adicional de 100\%).

${ }^{9}$ Citação é o ato processual através do qual a parte ré é cientificada de que se lhe está sendo movida uma ação judicial. Com a citação válida estabelece-se uma relação triangular entre os sujeitos envolvidos na ação: autor, réu e Estado (na pessoa do juiz).

${ }^{10}$ Esse novo valor de $R \$ 15.000,00$ foi apurado desse modo: 1.000 horas extras * $R \$ 10,00$ por hora x 1,50 (aplicação do adicional de 50\%). 
Assim se procederia a cada fase processual até que fosse definido o valor a pagar, quando, então, não mais se falaria em provisionamento, mas sim, em obrigação de curtíssimo prazo, precedendo, fornecedores, tributos e até mesmo, o salários do pessoal na ativa, nos termos do artigo $100, \S 1^{\circ}$ da Constituição Federal.

Machado (2009, p. 55) corrobora essa posição ao mencionar que:

Os créditos trabalhistas são dotados de natureza alimentar e preferencial, $\S 1^{\circ}$-A do art. 100 da CR/88 c/c art. 186 do CTN, porquanto constituem patrimônio social mínimo dos trabalhadores inerente à sua subsistência e necessidades básicas vitais, art. $6^{\circ} \mathrm{c} / \mathrm{c}$ art. $7^{\circ}$ da CR/88.

Então, após a definição do valor a pagar, de forma definitiva, o Poder Judiciário, no âmbito da Justiça do Trabalho, determina que o devedor faça o pagamento no prazo de 48 horas sob pena de penhora. Nesse sentido o artigo 880 da CLT que assim dispõe:

O Juiz ou Presidente do Tribunal, requerida a execução, mandará expedir mandado de citação ao executado, a fim de que cumpra a decisão ou o acordo no prazo, pelo modo e sob as cominações estabelecidas, ou em se tratando de pagamento em dinheiro, para que pague em 48 (quarenta e oito) horas, ou garanta a execução, sob pena de penhora.

Caso ocorra o pagamento voluntário e integral do valor em execução haverá sua extinção. Contudo, não havendo o adimplemento voluntário, independente da vontade do exeqüente o juiz pode determinar o prosseguimento da execução, com a prática de atos que visem sua satisfação, nos termos do artigo 878 da CLT ${ }^{11}$.

\footnotetext{
${ }^{11}$ Art. 878. A execução poderá ser promovida por qualquer interessado, ou ex officio pelo próprio Juiz ou Presidente ou Tribunal competente, nos termos do artigo anterior.

Parágrafo único. Quando se tratar de decisão dos Tribunais Regionais, a execução poderá ser promovida pela Procuradoria da Justiça do Trabalho.

Art. 878-A. Faculta-se ao devedor o pagamento imediato da parte que entender devida à Previdência Social, sem prejuízo da cobrança de eventuais diferenças encontradas na execução ex officio.
} 
Na execução ex officio a prática recomendada pela Corregedoria Geral da Justiça do Trabalho $^{12}$ é a adoção imediata da ferramenta eletrônica BACEN JUD, ou seja, o magistrado deve optar, preferencialmente, pela penhora eletrônica (de ativos financeiros do executado), por ser mais rápida e efetiva.

Aqui, o risco para o devedor (executado) que não se preparou para o pagamento é ver seus ativos financeiros (em especial os de curto prazo) constritos e indisponíveis, com substancial comprometimento de seu fluxo de caixa, o que pode levar à descontinuidade de suas operações.

Em situações ainda mais drásticas, é possível que o juízo (quando suspeitar da ocultação de recebíveis e de ativos financeiros) nomeie administrador judicial para localizar tais ativos e os indicar para a constrição judicial. Essa medida é preocupante, do ponto de vista do devedor porque pode implicar no bloqueio de seus recebíveis ${ }^{13}$, comprometendo o fluxo de caixa.

A questão é que, a ausência de informações quanto à referida obrigação, em todos os seus aspectos (que valor pagar e quando pagar) compromete os atos de gestão da organização devedora pois indica ao gestor um fluxo de caixa (ou um volume de disponibilidades) irreal, o que pode levar á realização de investimentos sem o devido lastro ou mesmo à equivocada distribuição de lucros.

Portanto, independente da forma como se dê a evidenciação aos usuários externos, os usuários internos da informação contábil precisam ter amplo acesso às mutações do risco legal trabalhista e de suas implicações no fluxo de caixa.

${ }^{12}$ Conforme artigo 18 da Consolidação dos Provimentos da Corregedoria Geral da Justiça do Trabalho

${ }^{13}$ Nessa situação, o administrador judicial localiza o valor a receber e solicita ao juízo que expeça ofício para que a pessoa (física ou jurídica) que deve pagar algo ao executado o faça mediante depósito judicial em conta à disposição do juízo. 


\subsubsection{Do tempo de tramitação da ação trabalhista}

As ações trabalhistas estão sujeitas á várias intercorrências em sua tramitação, que podem comprometer a estimativa quanto ao tempo de duração da lide e, consequentemente, em relação ao momento em que se espera ocorrer o desembolso, por parte da parte vencida, para o pagamento do valor da condenação que lhe foi imposta.

Dentre essas variáveis estão a existência de perícias, recursos, embargos, nulidades processuais e a existência de Cartas Precatórias.

Contudo, todas as unidades judiciárias, disponibilizam, mensalmente, controles estatísticos do tempo de tramitação das ações em trâmite e, esse volume de informações permitiu ao Tribunal Superior do Trabalho publicar estatísticas alusivas ao tempo médio de tramitação em $1^{\mathrm{a}}, 2^{\mathrm{a}}$ e $3^{\mathrm{a}}$ instâncias e, bem assim, cada Tribunal Regional do Trabalho possui estatísticas próprias de cada unidade de $1^{\mathrm{a}}$ instância.

Assim, ainda que não se possa precisar, exatamente, o tempo de tramitação de uma ação específica, é possível estimar o tempo médio de cada fase processual do feito e, então, é possível aferir o tempo médio estimado para que haja o desembolso do valor da condenação.

Os dados colhidos junto ao TST (2015), sinteticamente, indicam que, o tempo médio de tramitação de uma ação que percorra todas as instâncias judiciais ${ }^{14}$ é de 2672,9 dias, como consignado a seguir, na tabela 1:

\footnotetext{
${ }^{14}$ Sem a ocorrência de incidentes na execução.
} 
Tabela 1 - Tempo médio de tramitação de uma ação trabalhista (media país)

\begin{tabular}{|c|c|c|}
\hline $\begin{array}{l}\text { Unidade Judiciária / } \\
\text { Fase Processual }\end{array}$ & Descrição da etapa & $\begin{array}{c}\text { Tempo Médio } \\
\text { de Tramitação } \\
\text { (em dias) }\end{array}$ \\
\hline VT - conhecimento & $\begin{array}{c}\text { Do ajuizamento da ação até a realização da 1a } \\
\text { Audiência }\end{array}$ & 105,8 \\
\hline VT - conhecimento & $\begin{array}{l}\text { Da realização da 1ạ Audiência até o } \\
\text { Encerramento da Instrução Processual }\end{array}$ & 108,8 \\
\hline VT - conhecimento & $\begin{array}{c}\text { Do ajuizamento da Ação até a Prolação da } \\
\text { Sentença }\end{array}$ & 112,1 \\
\hline TRT & Da Autuação até o Julgamento & 229 \\
\hline TST & Tempo Médio de Tramitação - RR & 603 \\
\hline VT - Liquidação & Do início até o encerramento da Fase & 203,1 \\
\hline \multirow[t]{3}{*}{ VT - Execução } & Do início até o encerramento da Fase & 1311,1 \\
\hline & Total & 2672,9 \\
\hline & Total (em no de meses) & 89,1 \\
\hline
\end{tabular}

Fonte: TST, adaptado pelo autor

Com base em tais parâmetros (que são disponibilizados pelo TST para cada um dos TRTs) as companhias podem indicar, para cada ação judicial em andamento, classificada como perda provável, o tempo estimado para o desembolso, considerando-se como tal o término da fase de liquidação.

E, no mínimo, pode haver, sem maiores dificuldades, a evidenciação da quantidade de ações judiciais em andamento, segregadas pelo risco estimado (perda provável, perda possível e perda remota) e, ao menos pelas fases processuais (conhecimento, recursal, liquidação e execução). 


\subsection{Disposições contábeis}

Esse trabalho trata da evidenciação de passivo judicial contábil e de sua abordagem sob o prisma do conceito de valor justo, daí porque, do próprio título do trabalho exsurgem três tópicos contábeis a serem abordados: passivo, evidenciação e valor justo.

Para examinar a questão dos passivos judiciais é preciso resgatar, por primeiro, a conceituação de passivo e, também, a de passivo oculto, tendo em vista que as previsões de desembolso, nem sempre são realizadas de modo confiável, como explicitou Prestes $(2007)^{15}$.

ludícibus, por seu turno, (2000, p. 157) determina que o passivo pode ser definido:

Como obrigação no momento da avaliação. Uma obrigação é o dever ou a responsabilidade de agir ou de cumprir de uma certa forma. As obrigações podem ser legalmente executáveis como conseqüência de um contrato restritivo (obrigatório) ou de algum requisito estatutário ou legal.

Em complementação, Pereira et al. (2001, p. 109) destaca que, o passivo oculto pode surgir de "uma exigibilidade cuja informação acerca de sua existência permanece encoberta ao usuário externo dos demonstrativos contábeis e em alguns casos até dos próprios dirigentes". É o caso, então, por exemplo, de um passivo judicial não avaliado de modo correto.

Por primeiro, para o caso de passivo judicial, é necessário o tratamento como provisão, nos termos mencionados por ludícibus, Martins e Gelbcke (2003, p. 273). A partir do momento em que a decisão proferida no Judiciário é definitiva o valor da obrigação (oriundo da condenação) deve ser novamente calculado e lançado no Passivo Circulante.

${ }^{15}$ Op. Cit. 
Tal valor, até a data do efetivo pagamento, está sujeito à incidência de juros e de atualização monetária, nos termos do artigo 39 da Lei $8177 / 91^{16}$ e, portanto, não pode permanecer inalterado nos registros contábeis por prazo superior a 1 mês, cabendo, a cada período, ser promovido o ajuste alusivo à variação monetária e aos juros de mora.

No que concerne ao contingenciamento (enquanto não ocorre o trânsito em julgado da decisão de mérito) a valoração deve observar as mutações nos níveis de risco apresentadas na forma do item precedente - sem a ocorrência de qualquer tipo de limitação.

Ribeiro, Ribeiro e Weffort (2013) destacam que "as provisões são componentes importantes de um sistema contábil e se prestam a atender ao regime de competência dos fatos ocorridos, diferenciando-se do regime de caixa que depende da entrada ou saída de recursos de recursos financeiros" e que:

[...] antes da introdução das normas do IFRS $^{17}$ no Brasil, a contabilidade prestava-se, em muitos casos, principalmente a atender critérios de dedutibilidade fiscal e por isso mesmo as provisões eram estabelecidas para atender critérios impostos pela legislação tributária e normas da receita federal.

As provisões, elevam o valor do passivo e, portanto, produzem redução em determinados índices, em especial aqueles focados à liquidez. Poder-se-ia admitir a

\footnotetext{
${ }^{16}$ Art. 39. Os débitos trabalhistas de qualquer natureza, quando não satisfeitos pelo empregador nas épocas próprias assim definidas em lei, acordo ou convenção coletiva, sentença normativa ou cláusula contratual sofrerão juros de mora equivalentes à TRD acumulada no período compreendido entre a data de vencimento da obrigação e o seu efetivo pagamento.

$\S 1^{\circ}$ Aos débitos trabalhistas constantes de condenação pela Justiça do Trabalho ou decorrentes dos acordos feitos em reclamatória trabalhista, quando não cumpridos nas condições homologadas ou constantes do termo de conciliação, serão acrescidos, nos juros de mora previstos no caput juros de um por cento ao mês, contados do ajuizamento da reclamatória e aplicados pro rata die, ainda que não explicitados na sentença ou no termo de conciliação.

$\S 2^{\circ} \mathrm{Na}$ hipótese de a data de vencimento das obrigações de que trata este artigo ser anterior a $1^{\circ}$ de fevereiro de 1991, os juros de mora serão calculados pela composição entre a variação acumulada do BTN Fiscal no período compreendido entre a data de vencimento da obrigação e 31 de janeiro de 1991, e a TRD acumulada entre $1^{\circ}$ de fevereiro de 1991 e seu efetivo pagamento.

${ }^{17}$ International Financial Reporting Standards.
} 
hipótese de que as companhias, por esse prisma, teriam resistência a elevar os valores de suas provisões. Esse trabalho não cuida dessa questão, mas é importante observar que a qualidade da evidenciação dos critérios de reconhecimento e mensuração do passivo judicial pode contribuir para a análise dessa questão ${ }^{18}$.

No procedimento contábil vigente o provisionamento de passivos judiciais contingentes é feito em três categorias: remoto, possível e provável. Isso se dá em função da Resolução 489 da Comissão de Valores Mobiliários que aprovou a Norma e Procedimento de Contabilidade $22^{19}$ (IBRACON, 2005).

Tal NPC 22, em seu item 9, classifica os passivos contingentes em três grupos (provável, possível e remoto), da seguinte forma:

9. Para fins de classificação dos ativos e passivos em contingentes ou não, esta NPC usa os termos praticamente certo, provável, possível e remota com os seguintes conceitos:

(a) Praticamente certo - este termo é mais fortemente utilizado no julgamento de contingências ativas. Ele é aplicado para refletir uma situação na qual um evento futuro é certo, apesar de não ocorrido. Essa certeza advém de situações cujo controle está com a administração de uma entidade, e depende apenas dela, ou de situações em que há garantias reais ou decisões judiciais favoráveis, sobre as quais não cabem mais recursos.

(b) Provável - a chance de um ou mais eventos futuros ocorrer é maior do que a de não ocorrer.

(c) Possível - a chance de um ou mais eventos futuros ocorrer é menor que provável, mas maior que remota.

(d) Remota - a chance de um ou mais eventos futuros ocorrer é pequena.

Essa mesma norma determina que haja a constituição de provisão, apenas e tão somente, quando seja provável que recursos sejam exigidos para liquidar a obrigação $^{20}$. Para a hipótese da exigibilidade de saída de recursos ser apenas possível, a obrigação é de, tão somente, divulgar e, caso a exigibilidade seja

\footnotetext{
${ }^{18}$ Eventual supressão de provisionamento por conveniência.

${ }^{19}$ Doravante denominada como NPC 22.

${ }^{20}$ Conforme itens $10, \mathrm{~b}$ e 18.
} 
classificada como remota não é necessário provisionar e tampouco informar.

No caso de processos judiciais ${ }^{21}$ a NPC 22 destaca que a avaliação deve ser feita de forma conjunta, ou seja, a análise deve considerar todas as ações judiciais na classificação, indicando para cada ação se a exigibilidade de desembolso é provável, possível ou remota.

Em seguida, a norma reconhece as dificuldades de mensuração e estabelece que "o uso de estimativas é parte essencial da preparação das demonstrações contábeis e não prejudica sua confiabilidade". No contexto prático, tratando-se de ações judiciais, é comum que profissionais da área jurídica emitam relatórios a respeito do risco envolvido em cada demanda, o que é autorizado pelo item 30 da referida norma, que, assim dispõe:

30. As estimativas de desfecho e os efeitos financeiros são determinados pelo julgamento da administração da entidade, complementados pela experiência de transações semelhantes e, em alguns casos, por relatórios de especialistas independentes. As evidências consideradas devem incluir qualquer evidência adicional fornecida por eventos subseqüentes à data do balanço

A NPC 22, no tópico 35 sintetiza o critério para o estabelecimento de valor ao mencionar que "a melhor estimativa, considerando realisticamente o caso, é que deve ser observada" e, no item 44 a norma preconiza que a cada data base da demonstração contábil seja efetuada a revisão da classificação das provisões posto que aquilo que era remoto pode ser, agora, possível ou provável e o mesmo em sentido inverso (de provável para possível, por exemplo).

Nesse momento há uma norma contábil - de aplicação compulsória - formalizada no Direito Positivo que, de certa forma, contrapõe-se com a ideia do risco processual e, por assim ser, pode permitir que os valores provisionados não sejam os mais adequados para a evidenciação interna e externa. Assim ocorre em função da

\footnotetext{
${ }^{21}$ Essa NPC 22 cita, no item 19, processos trabalhistas como exemplo.
} 
tramitação processual, da alteração da jurisprudência, da autonomia do magistrado e de intercorrências, como a perda de prazos e de audiências.

Mesmo com revisões trimestrais, por conta dos ITRs, há tendência de que o foco de provisionamento seja o possível resultado futuro e não a situação atual da ação. Em ação que teve trâmite na $2^{\mathrm{a}}$ Vara do Trabalho de Betim/MG ${ }^{22}$ a Petrobras sofreu as penas de revelia e confissão pelo fato de seu preposto ter chegado atraso à audiência em função de congestionamento nas vias de acesso para aquela unidade judiciária. Apesar dos recursos interpostos, o TST (2013) manteve a decisão de $1^{0}$ grau.

A questão que se coloca é que a matéria objeto dessa ação poderia ser comum e, pelo histórico de demandas similares, talvez sequer houvesse risco de perdas, mas o fato de não comparecer à audiência, alterou a situação e isso deveria ser reconhecido no provisionamento.

Em 2009 o Comitê de Pronunciamentos Contábeis emitiu o CPC 25 - Provisões, Passivos Contingentes e Ativos Contingentes ${ }^{23}$ que acolheu a NPC 22, porém, com ajustes de modo a reconhecer, de modo mais efetivo, a subjetividade da estimativa de valores, que é uma das características das normas contábeis internacionais nesse particular.

Aqui, Ribeiro, Ribeiro e Weffort (2013) explicitam que:

O julgamento da empresa sobre a possibilidade de ocorrer, ou não, desembolsos de caixa futuros vai depender de documentação interna existente e no caso de contencioso tributário, de laudo emitido pelos seus advogados onde se apure valores, prazos e probabilidade de ocorrência destes eventos. A verificação final e aprovação dos valores com base nas evidências internas são feitas pelas empresas de auditoria externa. Como nas várias fases de determinação dos valores, prazos e probabilidades de ocorrência, os agentes

\footnotetext{
22 Processo AIRR-1091-55.2011.5.03.0027.

${ }^{23}$ Doravante denominado, nesse trabalho, simplesmente como CPC 25.
} 
envolvidos devem tomar decisões subjetivas quanto a constituir uma provisão ou a divulgar um passivo contingente em notas explicativas, o processo torna-se muito subjetivo e pode levar a práticas de gerenciamento contábil

Nesse contexto de subjetividade e de possível gerenciamento de resultados, o processo de evidenciação, não apenas de valores, mas, sobretudo, de critérios, passa a se tornar mais relevante para que o analista (interno ou externo) possa avaliar a ocorrência de eventuais escolhas de conveniência ou de práticas que levem a resultados contábeis não reais.

A questão, contudo, é que tal norma contábil (CPC 25) em seu item 39 trata da necessidade de buscar a melhor avaliação possível, com os meios necessários para cada situação, inclusive com o auxílio de especialistas. ${ }^{24}$

Necessário reconhecer que o risco envolvido na ação trabalhista não é constante e, portanto, para o processo de gestão há necessidade de mensurá-lo constantemente (a cada tramitação) e não apenas trimestralmente, porque nesse interregno a manutenção dos valores constantes pode comprometer o processo de gestão. Cabe buscar melhor interface entre as áreas financeira e jurídica para que as alterações no risco de cada ação (positivas ou negativas) sejam informadas para ajustes no provisionamento com maior brevidade.

\subsubsection{Qualidade da informação contábil}

Em conformidade com o item 1.4 da Resolução n. ${ }^{\circ}$ 774, de 16.12.1994, do Conselho Federal de Contabilidade (CFC) a Contabilidade tem por objetivo:

[...] prover os usuários com informações sobre aspectos de naturezas econômica, financeira e física do patrimônio da entidade e suas mutações, o que compreende registros, demonstrações, análises, diagnósticos e prognósticos, expressos sob a forma de relatos,

\footnotetext{
${ }^{24}$ Conforme item 38 do CPC 25.
} 
pareceres, tabelas, planilhas e outros meios.

Anterior à questão da evidenciação das informações contábeis e da definição do que é o valor justo, há que se lembrar da importância do processo de comunicação e como ele afeta o profissional da área contábil. Nesse sentido, Dias Filho (2001) expõe que:

\begin{abstract}
À luz dos fatores que determinam a fidelidade da comunicação, conclui-se que o sucesso da comunicação contábil depende, pelo menos em parte, do grau de acurácia com que os contadores consigam interpretar os eventos econômicos e codificá-los em mensagens compreensíveis.
\end{abstract}

Essa codificação em mensagens compreensíveis está ligada ao próprio conceito de externalização da informação ou evidenciação e é a primeira preocupação quando se busca falar em valor justo de um ativo, de um fato contábil ou de uma transação qualquer.

Juntamente com essa codificação surge a ideia (ou o questionamento) alusivo à confiabilidade da informação contábil. Assim ocorre porque, se a informação não é confiável, ela não poderá ser considerada ${ }^{25}$ no processo de tomada de decisão.

A confiabilidade da informação está relacionada à ausência de erros e/ou vieses, representando fielmente os eventos patrimoniais ocorridos na empresa, possuindo as seguintes características, segundo Glautier e Underdown (1994):

1. Conteúdo - se a informação é relevante, deverá ser demonstrada de maneira fidedigna as transações e eventos que ela objetiva representar, é necessário que ela apresente congruência com a realidade econômica e não meramente com a forma legal;

\footnotetext{
${ }^{25}$ Ao menos de forma integral.
} 
2. Valor descritivo e mensurável - a informação deverá ser capaz de ser mensurável e permitir a possibilidade de estabelecer projeções sobre eventos futuros;

3. Neutralidade - a informação não deve ser escolhida ou selecionada pelos gestores;

4. Precisão - a omissão da informação pode causar uma falsa informação ou pode direcionar para um entendimento não confiável ou deficiente;

5. Prudência - há preocupação em estabelecer estimativas quanto à ocorrência de eventos futuros que no momento de sua elaboração são incertos de ocorrerem.

Ainda descrevendo as características qualitativas da informação, Kam (1990) inclui na dimensão da informação confiável, a fidelidade. Para ele, essa característica é o mais importante elemento da confiabilidade. Destaca ainda que a informação fidedigna preocupa-se na compatibilização entre a mensuração ou descrição de um objeto econômico ou evento, dizendo se ele é representativo ou não.

Dessa forma a confiabilidade da informação contábil passa necessariamente pelo registro de eventos incorridos na empresa, bem como eventos que possam incorrer e trazer ao patrimônio impactos, que venham alterar o seu valor, destacando-se que a sua não evidenciação vai contra a um dos princípios básicos da informação confiável, que é a precisão.

Lima (2011, p.74) lembra que no Brasil, as normas e práticas contábeis apresentam características conservadoras, derivadas especialmente do regime tributário instituído. Tal aspecto pode ter reduzido a capacidade (e o hábito) de efetuar escolhas e de reconhecer a subjetividade de certos critérios contábeis, pois, até 
então, as práticas (pelo rigor fiscal) eram objetivas (para facilitar o controle do fisco).

Lopes (2002, p. 77) comenta que no cenário brasileiro há um outro agravante que é o fato do mercado de capitais ser muito concentrado o que leva ao acesso de informações privilegiadas ao acionista controlador que, assim, necessita menos de informações contábeis gerenciais. Nesse sentido, expõe que:

Essa alta concentração do mercado de capitais nacional tem
implicações diretas para a contabilidade. Em empresas com poucos
acionistas (no caso brasileiro, em muitas empresas o controle
acionário está nas mãos de um único acionista), a contabilidade
perde o seu papel de redutora da assimetria da informação entre
acionistas e gestores. Nessas empresas, o acionista majoritário
possui acesso privilegiado às informações gerenciais da empresa,
não necessitando da contabilidade para orientar suas decisões de
investimento.

Almeida (2010,p. 28) ressalva que a apuração do lucro é subjetiva ${ }^{26}$, daí porque a análise de sua qualidade ${ }^{27}$ é relevante para entender a motivação dos gestores a interferirem em sua mensuração e, bem assim, para entender como o lucro influencia tais agentes. Isso para aferir se há práticas de gerenciamento de resultado. Complementa (p. 33) mencionando que nem sempre os usuários da contabilidade podem capturar o sentido de uma escolha contábil adotada pela organização em função da subjetividade e das escolhas dos gestores.

A questão é que, se a contabilidade - e, por conseqüência a qualidade da informação contábil - for negligenciada poderá haver comprometimento (forte) para o usuário externo que pode, assim, incorrer em erros de julgamento pela ocorrência de vieses.

Não se buscará - em função do escopo desse trabalho - analisar se eventuais problemas com a qualidade das informações evidenciadas decorre de práticas de gerenciamento de resultado, cabendo, tão somente, explicitar como elas são

\footnotetext{
${ }^{26}$ Porque é um conjunto de diversas escolhas, políticas e estimativas contábeis.

${ }^{27}$ No sentido de confiabilidade.
} 
divulgadas e se atendem aos pressupostos do valor justo, aqui tratados.

\subsubsection{Evidenciação}

A ideia da evidenciação é a de propiciar informação aos tomadores de decisão (internos e externos). Niyama e Gomes (1996) indicam que evidenciar:

diz respeito à quantidade das informações de caráter financeiro e econômico, sobre as operações, recursos e obrigações de uma entidade, que sejam úteis aos usuários das demonstrações contábeis, entendidas como sendo aquelas que de alguma forma influenciem na tomada de decisões, envolvendo a entidade e o acompanhamento da evolução patrimonial, possibilitando o conhecimento das ações passadas e a realização de inferências em relação ao futuro.

Essas informações, contudo, devem primar pela qualidade e ausência de vieses e, bem assim, deve ser prestada em volume adequado pois, como menciona ludícibus (2000, p. 115), "ocultar informações ou fornecê-las de forma demasiadamente resumida é tão prejudicial quanto fornecer informação em excesso".

No entender de Lanzana (2004, p.13) a abertura de informações (ou disclosure) é um fator crítico para o funcionamento de um mercado de capitais eficiente, o que, então, reforça a importância de tal aspecto contábil.

Ponte e Oliveira (2004), ao examinar a prática da evidenciação de informações avançadas e não obrigatórias nas demonstrações financeiras das empresas brasileiras concluíram que "as empresas brasileiras em geral ainda têm muito a evoluir no sentido da transparência e qualidade da divulgação das informações contábeis". A questão, agora, é saber se, passados 10 anos houve algum tipo de evolução nesse sentido, em especial daquilo que não constitui obrigação imposta pelo direito positivo.

Almeida (2010, p. 141) concluiu que há evidências de que a competição (entre as empresas) pode contribuir para a divulgação de demonstrações financeiras de qualidade superior, principalmente se houver adoção de práticas diferenciadas de 
governança corporativa.

Macintosh e Baker (2002) estudaram a natureza da contabilidade em termos de sua natureza representativa mediante aproximação com a teoria literária para entender a natureza dos relatórios contábeis. O ponto de maior proximidade dá-se nas notas explicativas, onde ocorre o processo de evidenciação. Mencionam que uma "boa contabilidade" é aquela a representação dos eventos registrados ocorre dentro daquilo que os usuários reconhecem como senso comum.

$\mathrm{Na}$ continuidade, os autores ${ }^{28}$ mencionam que a contabilidade informa e a informação reflete de uma maneira objetiva e transparente alguma coisa em si mesmo, porém, conceitos como renda ou capital só podem ser sustentados invocando a filosofia para uma correspondência de verdade.

E aqui, inicia o problema que se trata nesse trabalho. Não só e renda remetem à filosofia, pela amplitude conceitual. Risco também. Por isso, que a ideia da evidenciação, deve observar não apenas parâmetros contábeis para atingir o senso comum, é necessário buscar o efetivo conceito (e amplitude) daquilo que se pretende mensurar.

Especificamente no contexto da evidenciação dos valores provisionados, a NPC 22 (IBRACON, 2005) trata do assunto nos itens 68 e 69, dessa forma:

68. Para cada tipo de provisão relevante, uma entidade deve divulgar:

(a) o valor contábil no início e no fim do período;

(b) provisões adicionais feitas no período, incluindo aumentos nas provisões existentes;

(c) montantes utilizados (ou seja, incorridos e baixados contra a provisão) durante o período;

(d) montantes não utilizados, estornados durante o período; e

(e) despesas financeiras apropriadas no período para as provisões ajustadas ao valor presente e qualquer mudança na taxa de desconto.

\footnotetext{
${ }^{28}$ Macintosh e Baker, ob. cit.
} 
Não são necessárias informações comparativas.

69. Além do descrito no item 68, uma entidade deve divulgar, para cada tipo de provisão relevante:

(a) uma breve descrição da natureza da obrigação e o cronograma esperado de quaisquer desembolsos;

(b) uma indicação das incertezas sobre o valor ou o cronograma desses desembolsos. Quando for necessário fornecer informações adequadas, uma entidade deve divulgar as principais premissas adotadas em relação a eventos futuros, conforme abordado no item 39; e

(c) o montante de qualquer reembolso esperado, declarando o valor de qualquer ativo que tenha sido reconhecido por conta desse reembolso.

Então, além da movimentação dos valores provisionados (saldo anterior, adições, deduções, valores utilizados e saldo final) a NPC 22 trata de duas outras informações relevantes que são: (a) uma breve descrição da natureza da obrigação e (b) no cronograma esperado de quaisquer desembolsos.

A evidenciação das estimativa de desembolso ${ }^{29}$ pode propiciar ao usuário interno melhor análise do fluxo de caixa e do capital de giro da organização e, para o usuário externo pode, dentre outros fatores, contribuir para a melhor compreensão de seus indicadores financeiros, em especial aqueles de liquidez.

Nesse mesmo sentido, o trabalho de Ribeiro, Ribeiro e Weffort (2013),concluiu que a evidenciação, em notas explicativas, dos critérios utilizados para o provisionamento pode eliminar erros de julgamento. Nesse sentido, os autores explicitam que:

[...] a divulgação de contingências em notas explicativas reduzirá assimetrias de informação; foi comentado ser muito importante para as companhias divulgarem informações em notas explicativas, pois este procedimento poderá cobrir lacunas e eliminar erros de julgamentos. A informação fica transparente ao mercado e mesmo que mudem as estimativas de possibilidades de perda ou ganho de processos, o mercado já estará ciente de sua existência. Um ponto visto como muito positivo foi a exigência de se divulgar a movimentação detalhada das provisões nas notas explicativas, mas alertou-se para se tomar cuidado para não divulgar somente o efeito

\footnotetext{
${ }^{29}$ Ideia de um cronograma.
} 
líquido, o que prejudicará a transparência das demonstrações financeiras.

Buscar-se-á, nos tópicos seguintes dessa revisão da literatura a identificação daquilo que deve ser evidenciado nas notas explicativas alusivo ao passivo judicial trabalhista e às provisões daí decorrentes.

\subsubsection{Valor justo}

Guerreiro (1989, p. 99) menciona que:

a contabilidade, obedecendo ao princípio do denominador comum monetário, tem utilizado somente a escala monetária para mensurar os objetos e eventos. Entendemos contudo, que principalmente para finalidades gerenciais, os sistemas de informações contábeis deveriam fornecer informações mensuradas tanto pela unidade monetária, como por escalas físicas

Por essa proposição de Guerreiro já se pode verificar que a atribuição de valor (em princípio monetário) não é tarefa das mais simples e, em muitos casos, a informação não monetária é mais importante.

Nesse sentido, informar o momento (cronograma) em que se espera que os desembolsos sejam exigidos pode vir a ser mais importante que a mera indicação do valor provisionado. Do mesmo modo, a indicação quanto à quantidade de ações em andamento e à origem do passivo judicial podem constituir informações mais relevantes, inclusive sob o prisma da análise de gerenciamento do risco ${ }^{30}$.

Scrimnger-Christian e Musvoto (2011) discutem a questão da mensuração contábil e dos critérios utilizados para determinar as quantias monetárias que serão

${ }^{30}$ Pode ser relevante aferir se a quantidade de ações tem tendência de aumento ou de decréscimo. E, um provisionamento de $\$ 1.000 .000$ exigível em 15 meses (não circulante) é distinto de outro exigível em 36 meses (também no não circulante). 
reconhecidas e levadas para as demonstrações financeiras. Apresentam a evolução histórica das teorias e mencionam, ao final, que é necessário achar a identidade empírica dos axiomas de valor (ainda não bem definidas).

Considerando que o resultado contábil busca uma aproximação da realidade (ou do valor justo) e que essa busca não pode ser limitada pelo formalismo das normas profissionais da categoria contábil ou dos questionamentos promovidos pelos stakeholders, tem-se que, independente da ferramenta utilizada para a mensuração, somente se poderá falar em valor justo após forte sustentação do processo de evidenciação das informações contábeis e da mitigação dos efeitos provocados pela assimetria das informações.

Isso para que o usuário, recebendo as informações completas sobre as características das ações judiciais, possa analisar os critérios e, por si, deliberar se o quanto evidenciado foi avaliado pelo valor justo. Não se poderá, por outro lado, falar em valor justo, se não há informações completas, disponíveis aos stakeholders.

Segundo o Statement of Financial Accounting Standards no 107 (SFAS n. ${ }^{\circ}$ 107) Disclosures about Fair Value of Financial do FASB, o fair value de um ativo corresponde ao valor pelo qual esse instrumento poderia ser trocado em uma transação corrente entre partes interessadas, outra que não em uma liquidação ou venda forçada.

A NBC TG 46 (R1) - Mensuração do Valor Justo define, em seu item 9, valor justo como sendo:

o preço que seria recebido pela venda de um ativo ou que seria pago pela transferência de um passivo em uma transação não forçada entre participantes do mercado na data de mensuração.

Mais adiante, o item 12, a NBC TG 46 explicita que:

O efeito sobre a mensuração resultante de uma característica específica pode diferir dependendo de como essa característica é levada em consideração pelos participantes do mercado. 
E, essas características específicas são comuns quando se trata de ações judiciais, eis que, por mais que os pleitos sejam idênticos e, bem assim, também as defesas, mas os resultados podem ser distintos, em função das decisões que venham a ser proferidas, dos prazos e das provas produzidas, por exemplo, o que indica a necessidade de evidenciação dos critérios de mensuração do provisionamento.

Ao tratar de valor justo de passivos, essa norma (NBC TG 46) preceitua que:

Ao mensurar o valor justo de um passivo, a entidade deve levar em conta o efeito de seu risco de crédito (situação de crédito) e quaisquer outros fatores que possam influenciar a probabilidade de que a obrigação seja ou não satisfeita. Esse efeito pode diferir dependendo do passivo. Por exemplo:

(a) se o passivo é uma obrigação de entregar caixa (passivo financeiro) ou uma obrigação de entregar bens ou serviços (passivo não financeiro);

(b) os termos de melhorias de crédito relacionados ao passivo, se houver.

No caso de passivo judicial, o risco é de crédito e decorre de uma possível obrigação de entregar caixa.

Também, para que se possa falar em valor justo é necessário analisar os efeitos de determinado fato (ou transação ou decisão) no futuro e, para tanto, têm-se que observar a lição de ljiri, sintetizada no exemplo de Ferreira et al (2009, p. 102):

A Contabilidade Multidimensional procura demonstrar que empresas
com balanços iguais no final de um ano não necessariamente
tiveram o mesmo movimento patrimonial ao longo do período, pois
pode ter havido uma aceleração ou desaceleração, isto é, uma
empresa pode ter começado o ano com crescimento e terminado
com uma redução deste crescimento ou começado mal e terminado
o ano em crescimento. Uma empresa pode estar vivendo um ciclo de
crescimento ou encarando um período difícil, isto é, o movimento
patrimonial pode estar com uma aceleração positiva ou negativa, e
através dessa análise poderá ser avaliado como será a
movimentação patrimonial futura.

Pelo exemplo supra, um mesmo valor presente resultará em valor futuro diferente e conseqüentemente em valor justo diferente - porque o movimento patrimonial terá acelerações diferentes em organizações diferentes. 
Essa ideia de movimento também está presente na avaliação dos riscos de uma determinada ação judicial e da mensuração de valor a provisionar porque ações com provisionamentos iguais mas em fases processuais diferentes poderão ter resultados futuros muito distintos.

Então, o que se busca denominar como valor justo, deve ser suportado, no mínimo, por um tripé formado pela Teoria da Contabilidade (técnicas de mensuração e de evidenciação), pelo Direito Positivo (o conjunto de normas que determina como se reconhece e explicita valor e pelas normas processuais aplicáveis na ação trabalhista) e pelo Direito Natural (no contexto de obrigação natural para definir o que, sem limites, deveria ser reconhecido e evidenciado).

Retomando essa questão da movimentação patrimonial (aceleração ou desaceleração) e aplicando-a na questão dos passivos judiciais trabalhistas, podese identificar a necessidade de indicar a fase processual de cada uma das demandas que a empresa (organização) tem contra si. Assim ocorre porque uma demanda no início deverá ter tratamento diferenciado de uma com decisão definitiva e sem possibilidade de recursos (transitada em julgado) ${ }^{31}$.

Para a primeira situação, o caso é de provisionamento e o valor estará sujeito a uma gama de incertezas e subjetividades. Para a segunda situação, não se fala mais em provisionamento, mas em obrigação de curto prazo $^{32}$, com valor objetivamente definido, no aguardo da determinação judicial para o pagamento.

Quando do recebimento de uma ação trabalhista contra si, a entidade, nos termos do Pronunciamento Técnico CPC 25 cuida de elaborar uma provisão ${ }^{33}$ eis que há a possibilidade $^{34}$ de uma condenação e, para esse caso, trata-se de um passivo de

\footnotetext{
${ }^{31}$ Relembre-se a alínea "a" do item 69 da NPC 22 que trata da divulgação do cronograma de desembolso. O cronograma poderia ser complementado com as fases processuais de cada ação, ainda que de forma global.

${ }^{32}$ Necessária a transformação da provisão em conta de passivo circulante (obrigação de pagar) no momento em que há definição do valor a ser pago.

${ }_{33}^{33}$ Caso entenda que há possibilidade de vir a efetuar desembolso para adimplir a obrigação.

${ }^{34}$ Ainda que remota, considerando-se casos históricos similares, porque, até que se compareça em
} 
prazo ou de valor incertos.

O referido pronunciamento utiliza a expressão "contingente" para designar que "sua existência somente será confirmada pela ocorrência ou não de um ou mais eventos futuros incertos não totalmente sob o controle da entidade".

Dentre esses eventos futuros estão a produção de provas ao longo da ação (que modificam o risco), o comportamento processual e, as decisões que vierem a ser proferidas pelo juízo.

Quando a decisão transitar em julgado, não se pode mais falar em contingente porque, em tal situação, não mais dúvida quanto ao valor ou ao prazo: a obrigação passa a ser de curtíssimo prazo.

Com a movimentação devem ser feitos os ajustes contábeis, evento a evento e, ao final de cada período, devem ser informadas no balanço, conforme o item 59 do CPC 25. Esses valores, avaliados em cada movimentação, por especialistas independentes é que poderia (ao menos no âmbito interno, por enquanto) ser classificado como valor justo.

Para a obtenção dos valores a provisionar, nos termos do item 25 do CPC 25 a entidade "é capaz de determinar um conjunto de desfechos possíveis e, dessa forma, fazer uma estimativa da obrigação que seja suficientemente confiável para ser usada no reconhecimento da provisão".

Externar a forma pela qual fez a provisão e sua "visão" a respeito dos riscos envolvidos toca nos conceitos de fair value e de evidenciação, daí porque deveriam constar em notas explicativas.

audiência inicial, devidamente representada, e apresente a defesa, há o risco de revelia e de confissão, como aconteceu com o processo da Petrobrás em Betim/MG, já mencionado nesse trabalho. 
A referida determinação é complementada pelo item 38 do CPC 25 ao mencionar que:

As estimativas do desfecho e do efeito financeiro são determinadas pelo julgamento da administração da entidade, complementados pela experiência de transações semelhantes e, em alguns casos, por relatórios de peritos independentes. As evidências consideradas devem incluir qualquer evidência adicional fornecida por eventos subsequentes à data do balanço.

Há determinação quanto à evidenciação dos critérios adotados em cada classe de provisão, através do item 85 do CPC 25, abaixo transcrito e dos itens 127 e 129 do CPC 26:

A entidade deve divulgar, para cada classe de provisão:

(a) uma breve descrição da natureza da obrigação e o cronograma esperado de quaisquer saídas de benefícios econômicos resultantes;

(b) uma indicação das incertezas sobre o valor ou o cronograma dessas saídas. Sempre que necessário para fornecer informações adequadas, a entidade deve divulgar as principais premissas adotadas em relação a eventos futuros, conforme tratado no item 48;

(c) o valor de qualquer reembolso esperado, declarando o valor de qualquer ativo que tenha sido reconhecido por conta desse reembolso esperado.

Assim, o valor justo do passivo judicial trabalhista é aquele que considera a fase atual de cada ação (risco presente), acompanhado de informações quanto à data estimada do desembolso, à quantidade de ações em andamento e à origem das mesmas.

\subsection{Obrigação natural}

Para Gobert (1957, p. 21) a "obrigação natural é um dever legitimamente e racionalmente susceptível de se tornar o objeto de coerção exterior" porém sem ser 
munida de ação ${ }^{35}$. Essa, conforme a literatura, é a distinção entre uma obrigação civil e uma obrigação natural: a possibilidade de buscar a tutela do Estado para coagir o devedor a adimplir a obrigação.

Nesse sentido, Velasco (1990, p. 72) explicita que as obrigações naturais são aquelas que constringem, exclusivamente, o foro da consciência, carecendo do direito de ação.

Guyau (1944, p. 17) inicia sua obra a respeito da obrigação natural aduzindo que é necessário pressupor a existência do livre arbítrio, de uma faculdade de eleição porque, sem liberdade absoluta não há responsabilidade absoluta, não há mérito e não há demérito.

Posicionando essa ideia dentro do cenário contábil em que a evidenciação se insere pode-se dizer que, meramente cumprir (ou atender) as obrigações do direito positivo $^{36}$ não pode ser considerado como mérito, porque a isso, todos (nessa condição) estariam obrigados. A questão é aferir quem, com ampla liberdade (de fazer ou de não fazer), ou seja, em plena faculdade eletiva exerce o seu livre arbítrio.

Adiante, Guyau ${ }^{37}$ menciona que no mérito moral é preciso transformar, diante dos próprios olhos, a matéria da ação meritória e atribuir-lhe valor superior ao seu valor real. Menciona que é necessário uma comparação não apenas entre a vontade e a lei, senão também entre o esforço moral e o preço do fim que se persegue.

Aqui, o autor trata de uma causa, de algo moral (e maior) que impele o indivíduo na consecução desse fim. No contexto contábil isso poderia, por exemplo, ser destacado como um desejo maior de transparência e de responsabilidade social.

\footnotetext{
${ }^{35}$ Aqui entendido como o direito de execução forçada.

${ }^{36}$ Onde o conjunto de normas contábeis está inserido.

${ }^{37}$ Op. Cit. (p. 56).
} 
Assim é que, ainda conforme Guyau ${ }^{38}$ a força do sentimento moral adquire um caráter cada vez mais notável quando toma a forma, não de um impulso ou de uma repressão súbita, senão de uma pressão interior, de tensão constante. O autor ainda menciona que na maioria dos casos e na maioria das pessoas o sentimento de dever não é violento, mas sim durável: há falta de intensidade.

Não se pode, pois, meramente coagir a fazer (ou a deixar de fazer) ou mesmo, agir de rompante (para o sim ou para o não). É necessário desenvolver (ou se permitir) que a força interior (que conduzirá ao esforço moral) se desenvolva, o que, no contexto das organizações fará parte da cultura organizacional e de seus valores.

A situação supra (ligada à moral) está ligada à ideia de obrigação natural. Nesse sentido, Moisset de Espanés (1998, p. 21) menciona que tanto o direito como a moral são ordenamentos normativos que tem relação com a conduta do homem. Esclarece que muitos pensadores tem procurado traçar uma divisão entre essas duas ordens o que, no seu entender, é impossível porque, muito ao contrário, o direito e a moral estão intimamente compenetrados.

Moisset de Espanés $^{39}$ continua sua exposição mencionando que, na realidade, a diferença entre a moral e o direito reside apenas na análise dos deveres que um e outro tipo de ordenamento impõem à natureza humana e que, por conta disso, é necessário aferir quando um dever é simplesmente moral e quando transcende ao ordenamento jurídico.

Posto isso Moisset de Espanés menciona que há uma infinidade de deveres morais que jamais poderão ter projeção no campo jurídico. Nesse conjunto estão aqueles que se referem, exclusivamente, às regras de conduta interna e que dizem respeito ao aspecto individual do indivíduo e ao seu desenvolvimento, sem extrapolar essa condição. Outros deveres morais (como cortesia, decoro, benevolência) regulam condutas que produzem efeitos em outras pessoas mas também não ingressam no

\footnotetext{
${ }^{38}$ Op. Cit. (p. 110).

${ }^{39}$ Op. Cit. (p. 25).
} 
ordenamento jurídico.

A questão é que o Moisset de Espanés ${ }^{40}$ enfatiza que os estímulos de consiciência obrigam mais que quantos forem os vínculos criados pelo Direito porque eles constituem um dever moral que serve de causa válida a obrigação.

Essa observação é importante para que se reconheça que determinados procedimentos contábeis (como a evidenciação das provisões) não necessitam, exatamente, de regulações positivas, sendo mais importante estimular as organizações e seus gestores para que, de modo contínuo, passem a explicitar os atos de gestão e os fundamentos de suas escolhas contábeis.

Depois dessa parte introdutória, onde Moisset de Espanés ${ }^{41}$ diferencia o dever moral do dever jurídico ele adentra ao estudo da obrigação natural mencionando que quando uma relação conta com todos os elementos essenciais próprios de uma obrigação e tanto os sujeitos (credor e devedor), como o objeto (prestação) estão perfeitamente determinados, a falta de exigibilidade não suprime a existência do vínculo já que há um débito que não foi extinto. Nesse tipo de caso há a caracterização de uma obrigação natural.

Velasco (1990, p. 28) efetua a distinção entre o dever moral e a obrigação natural, mencionando que esta é extrajurídica, embora com certos e parciais efeitos dentro do Direito. Trata-se de obrigação jurídica, porém imperfeita porque é incoercível, posto que nasce no foro da consciência e não no Direito.

E, Velasco continua com essa distinção mencionando que o fundamento extrajurídico da obrigação natural é o dever moral e que este não se identifica com aquela porque um e outra estão em campos distintos, respectivamente extra e intra jurídicos. Porém, o fundamento jurídico está na equidade, concebida como dispositivo negativo para erradicar a injustiça do sistema jurídico positivo.

\footnotetext{
${ }^{40}$ Op. cit. (p. 160)

${ }^{41}$ Ob. cit. (p. 152).
} 
Covello (1996, p. 27) destaca que "a pouco e pouco a noção de obrigação natural ampliou-se a ponto de quase confundir-se com o devedor moral". Mais adiante ${ }^{42}$, explicitando a importância desse instituto jurídico, menciona, na forma seguinte, que as obrigações naturais correspondem aos puros e simples deveres de justiça.

\begin{abstract}
As obrigações naturais constituem assim casos intermédios entre os puros deveres de ordem moral ou social e os deveres jurídicos. Os primeiros fundamentam liberalidades, os últimos consubstanciam obrigações civis munidas de ação. No campo delimitado pelas duas fronteiras é que se situam as hipóteses a qualificar como obrigações naturais. Para o efeito operará o interprete com a diretriz fornecida pelo legislador. E acabamos de ver que se exige, antes de tudo, a existência de um dever moral ou social, mas não apenas isso. Exigese, ainda, que o dever moral ou social de prestar corresponda também a um dever de justiça. Aquele sem este poderá ocasionar uma liberalidade e nunca o cumprimento de uma obrigação natural. Ora, como os devedores de justiça constituem simultaneamente deveres morais ou sociais, poderá sintetizar-se numa formulação abreviada, que as obrigações naturais correspondem aos puros e simples deveres de justiça
\end{abstract}

Assim, se é necessária a existência de dever moral ou social e se a obrigação natural corresponde (na essência) aos "puros e simples deveres de justiça" é, dentro desse contexto que se deve incluir o conceito de valor justo.

Na conceituação jurídica, segundo Barros (2006) o valor justo se divide em valor justo natural e valor justo legal, que é aquele imposto por determinado regramento, como, por exemplo, o critério estabelecido pelo FASB. Indica, também, que o valor justo natural é variável, porém, mais estável que o valor justo legal, dessa forma:

[...] o justo natural possui uma razão de validade que não depende do parecer humano e representa, desde a origem, a única possibilidade de solução, sendo anterior a qualquer intervenção humana e tendo seu conteúdo fundamentado na própria natureza das coisas. No entanto, segundo Aristóteles, isso não implica que ele seja totalmente imutável, pois a invariabilidade é reservada ao domínio dos deuses: o justo natural não é como o fogo, que brilha igualmente em todo lugar. A partir do momento em que se vincula à

${ }^{42}$ Op. cit. (p. 35) 
atividade humana - e o estabelecimento do justo está necessariamente ligado ao mundo humano, portanto, das realidades contingentes - torna-se também sujeito às mudanças. Porém, sua variação é bem menor do que o justo legal: enquanto este sofre mudanças freqüentes, porque tem seu fundamento na vontade do homem, aquele só a experimenta de maneira excepcional, revelando sempre uma maior generalidade e permanência

Essa ideia de um valor justo é abrangente e o valor daí decorrente também é sujeito à mudanças. Ocorre que, se explicitado o critério e, se esse critério for aceito como justo, o valor mensurado aproximar-se-á, mais, do conceito de justo e, por isso poderá ser mais efetivo no processo de tomada de decisão.

\subsection{Formação do conceito de evidenciação do passivo judicial trabalhista alinhado ao conceito de valor justo}

Consolidando as disposições positivas (CPCs 25 e 26) e aquelas oriundas do direito natural (informação ampla e compreensível ao tomador de decisão) tem-se que, independente da estrutura das notas explicativas, deve haver informação em relação às perspectivas da entidade em relação aos riscos de desembolsos futuros (valores) por conta de demandas judiciais trabalhistas (origem) e, bem assim, em relação aos momentos em que tais saídas de caixa são esperadas (cronograma).

Nesse sentido, qualquer que seja o valor divulgado ele deve vir acompanhado de três qualificadores (origem, forma de mensuração e previsão de desembolso).

A origem refere-se ao fato administrativo-jurídico que lhe deu origem. Aqui, tratandose de direitos trabalhistas buscados em uma determinada ação essa origem pode referir-se,por exemplo, a horas extras, diferenças salariais, participação em lucros e resultados e qualquer outra verba amparada pelo direito laboral e passível de litigância perante a Justiça do Trabalho.

Importante que se possa analisar a origem (e comparar ano a ano) para que, no contexto de responsabilidade social se possa avaliar o comportamento dos gestores quanto à mitigação desses riscos, em seus fatos geradores. 
Para a sistematização da análise a respeito da evidenciação do valor justo, propõese a estruturação em três grupos, a saber:

- Representatividade das provisões;

- Reconhecimento e mensuração;

- Outras práticas de evidenciação.

No grupo de representatividade das provisões busca-se aferir a exposição da companhia a risco financeiro, em virtude de eventual comprometimento de seu fluxo de caixa.

Para tanto, foram calculadas as relações percentuais entre o valor provisionado e métricas contábeis associadas ao curto prazo e às atividades operacionais, quais sejam: caixa, capital circulante líquido e EBITDA. Nesse ponto, quanto mais elevada for a relação percentual, maior será a exposição ao risco.

Quanto ao segundo grupo (reconhecimento e mensuração) cuidou-se de analisar a origem do passivo judicial, a forma de constituição das provisões, a quantidade de ações judiciais trabalhistas e o estimado cronograma de desembolsos para essas obrigações.

No terceiro grupo (outras práticas de evidenciação) foram destacadas as boas práticas que podem ser implementadas pelas demais companhias e que estão alinhadas com a fundamentação teórica aqui exposta e práticas que não deveriam ser adotadas (por contrariar os preceitos do direito natural, impedindo 0 reconhecimento de valor justo).

O quadro 1, apresentado abaixo, demonstra a estrutura confeccionada para a análise das notas explicativas das demonstrações financeiras. 


\begin{tabular}{|c|c|}
\hline Grupo & Objeto \\
\hline \multirow[t]{3}{*}{ Representatividade } & 1. relação da provisão com o caixa \\
\hline & 2. relação da provisão com o capital circulante líquido \\
\hline & 3. relação com o EBITDA \\
\hline \multirow{4}{*}{$\begin{array}{l}\text { Reconhecimento e } \\
\text { Mensuração }\end{array}$} & 1. Origem do passivo judicial \\
\hline & 2. Forma de constituição da provisão \\
\hline & 3. Quantidade de ações trabalhistas \\
\hline & 4. Cronograma de desembolso \\
\hline \multirow[t]{2}{*}{ Outras práticas } & 1. Boas práticas \\
\hline & 2. Práticas não alinhadas aos princípios do direito natural \\
\hline
\end{tabular}

Quadro 1: Sistematização do processo de análise (parte descritiva e exploratória) 


\section{MÉTODO DE PESQUISA}

O presente trabalho é alicerçado em pesquisa descritiva que, conforme ensina Malhotra (2001, p. 108), "tem como principal objetivo a descrição de algo". Ela descreve uma situação, um fenômeno, uma amostra ou uma população e tem como fundamento aprofundar o conhecimento sobre uma situação para, posteriormente, identificar motivos, características e particularidades que contribuíram (ou originaram) aquela situação (atribuições da pesquisa explicativa).

Característica desse tipo de pesquisa é apoiar-se em procedimentos da estatística descritiva, como distribuição de freqüência e medidas de tendência central.

Utilizou-se, também, a técnica da análise de conteúdo que, como destacam Dencker e Viá (2002, p. 179) é aplicada para classificar em categorias pré determinadas, elementos textuais que se pretende analisar.

O presente trabalho também tem característica exploratória porque não há estudos anteriores sobre a evidenciação do passivo judicial trabalhista, de modo isolado, daí porque tornou-se necessário explorar o formato pelo qual as provisões constituídas para fazer frente a tais obrigações são evidenciadas pelas companhias objeto de exame.

\subsection{Definição da amostra}

No caso em exame a população é constituída pelas companhias listadas nos Níveis 1, 2 e Novo Mercado de Governança Corporativa da BM\&FBovespa que, compreende 181 empresas.

Ocorre que, dentre as empresas listadas há holdings e outras que possuem como característica a diminuta quantidade de empregados. Tais empresas poderiam causar vieses na análise, se analisadas em conjunto com as demais e, por essa razão foram excluídas da amostra. 
Assim, para a definição da amostra entendeu-se que duas possibilidades se sobressaiam, quais sejam: (a) escolhas em função da quantidade de empregados e (b) escolhas em função da litiogisidade (quantidade de ações judiciais).

A opção em função da quantidade de empregados foi descartada porque, em função de políticas financeiras e de gestão de recursos humanos - é possível que uma empresa com grande quantidade de empregados tenha uma pequena quantidade de ações trabalhistas e, em função disso, seu passivo judicial trabalhista pode ser ínfimo.

De outra parte, há casos de empresas que possuem grande volumes de ações ajuizadas contra si, mas os casos são solucionados ainda na fase de conhecimento através de conciliação. Essa situação poderia, inclusive, caracterizar uma forma de obter ganhos financeiros com as ações trabalhistas (hipótese não tratada nesse trabalho).

Nesse contexto, optou-se pela análise das empresas em função da litiogisidade. E, como parâmetro de tal métrica escolheu-se a quantidade de ações em andamento, envolvendo determinada parte, no Tribunal Superior do Trabalho.

Excetuando ações que possam ter competência originária nos Tribunais, as demais percorreram todas as instâncias da Justiça do Trabalho, sinalizando o ânimo das partes em litigar ${ }^{43}$. E, essas ações que percorrem todas as instâncias são aquelas mais propícias a permaneceram por maior tempo no passivo da entidade, ensejando, ajustes de valor e eventuais reclassificações quanto ao momento de sua exigibilidade.

Para aferir, então, quais empresas seriam analisadas promoveu-se consulta junto ao sitio do Tribunal Superior do Trabalho. A consulta foi feita no documento

\footnotetext{
${ }^{43}$ Poder-se-ia supor, ainda, que tais ações possuem maior relevância financeira, eis que há custos para litigar até a instância superior, os quais não seriam compensatórios para ações de pequeno valor financeiro.
} 
denominado como Ranking das Partes que é uma publicação anual da Coordenadoria de Estatística e Pesquisa do Tribunal Superior do Trabalho e que relaciona as partes (pessoas físicas ou jurídicas) que possuam 100 ou mais ações em tramitação naquele órgão. A condição da parte pode ser passiva (recorrido) ou ativa (recorrente).

Assim, consultou-se o referido ranking e promoveu-se o cotejo com a lista de empresas pertencentes ao níveis 1, 2 e Novo Mercado de Governança Corporativa da BMFBOVESPA. Todas as empresas de tais níveis listadas no ranking foram inseridas na amostra.

$\mathrm{Na}$ tabela 2, apresentada a seguir, estão relacionadas as 40 (quarenta) empresas incluídas na amostragem, Observe-se que o quadro apresenta a listagem das empresas tal qual apresentado no ranking do TST, porém, na análise foram considerados os dados consolidados, sempre que as empresas pertenceram a um mesmo grupo controlador.

Tabela 2 - Relação de empresas incluídas na amostragem

\begin{tabular}{c|c|l|r|r|r} 
Ordem & Ranking & Nome da Parte & $\begin{array}{r}\text { Polo } \\
\text { Ativo }\end{array}$ & $\begin{array}{r}\text { Polo } \\
\text { Passivo }\end{array}$ & Total \\
\hline 1 & $157^{\circ}$ & AES SUL DISTR. GAÚCHA DE ENERGIA S.A. & 180 & 94 & 274 \\
\hline 2 & $104^{\circ}$ & ALPARGATAS S.A. & 53 & 368 & 421 \\
\hline 3 & $429^{\circ}$ & AREZZO INDÚSTRIA E COMÉRCIO S.A. & 100 & 6 & 106 \\
\hline 4 & $12^{\circ}$ & BANCO BRADESCO S.A. & 1.336 & 2.503 & 3.839 \\
\hline 5 & $3^{\circ}$ & BANCO DO BRASIL S.A. & 6.382 & 5.173 & 11.555 \\
\hline 6 & $57^{\circ}$ & BANCO DO EST.RIO GRANDE SUL S.A. - BANRISUL & 474 & 229 & 703 \\
\hline 7 & $222^{\circ}$ & BANCO PANAMERICANO S.A. & 56 & 131 & 187 \\
\hline 8 & $254^{\circ}$ & BIOSEV BIOENERGIA S.A. & 110 & 58 & 168 \\
\hline 9 & $155^{\circ}$ & BRASKEM S.A. & 175 & 100 & 275 \\
\hline 10 & $36^{\circ}$ & BRF S.A. & 737 & 311 & 1.048 \\
\hline 11 & $303^{\circ}$ & CELESC DISTRIBUIÇÃO S.A. & 40 & 103 & 143 \\
\hline 12 & $43^{\circ}$ & CEMIG DISTRIBUIÇÃO S.A. & 583 & 289 & 872 \\
\hline 13 & $40^{\circ}$ & CIA. BRASILEIRA DE DISTRIBUIÇÃO & 688 & 234 & 922 \\
\hline 14 & $121^{\circ}$ & CIA. ENERGÉTICA DE SÃO PAULO - CESP & 125 & 334 & 459 \\
\hline 15 & $97^{\circ}$ & CIA. EST. DE DISTR. EN. ELÉTRICA - CEEE - D & 407 & 276 & 683 \\
\hline 16 & $60^{\circ}$ & CIA. EST. DE GER. TRANSM.EN. ELÉT.- CEEE - GT & 392 & 377 & 769 \\
\hline 17 & $53^{\circ}$ & CIA. DE SAN. BÁSICO EST. SÃO PAULO - SABESP & 406 & 241 & 647 \\
\hline 18 & $62^{\circ}$ & CIA. PARANAENSE DE ENERGIA - COPEL & 218 & 277 & 495
\end{tabular}




\begin{tabular}{c|c|l|r|r|r} 
Ordem & Ranking & Nome da Parte & $\begin{array}{r}\text { Polo } \\
\text { Ativo }\end{array}$ & $\begin{array}{r}\text { Polo } \\
\text { Passivo }\end{array}$ & Total \\
\hline 19 & $88^{\circ}$ & CIA. PAULISTA DE FORÇA E LUZ - CPFL & 88 & 85 & 173 \\
\hline 20 & $241^{\circ}$ & ELETROPAULO METROP. ELETR. SÃO PAULO S.A. & 319 & 600 & 919 \\
\hline 21 & $41^{\circ}$ & FIBRIA CELULOSE S.A. & 114 & 69 & 183 \\
\hline 22 & $231^{\circ}$ & GERDAU AÇOMINAS S.A. & 52 & 50 & 102 \\
\hline 23 & $320^{\circ}$ & GOL LINHAS AÉREAS INTELIGENTES S.A. & 47 & 89 & 136 \\
\hline 24 & $321^{\circ}$ & ITAÚ UNIBANCO S.A. & 2.285 & 3.078 & 5.363 \\
\hline 25 & $6^{\circ}$ & JBS S.A. & 895 & 157 & 1.052 \\
\hline 26 & $35^{\circ}$ & JSL S.A. & 120 & 34 & 154 \\
\hline 27 & $285^{\circ}$ & KLABIN S.A. & 128 & 81 & 209 \\
\hline 28 & $206^{\circ}$ & LIGHT SERVIÇOS DE ELETRICIDADE S.A. & 109 & 63 & 172 \\
\hline 29 & $247^{\circ}$ & LOJAS RENNER S.A. & 308 & 80 & 388 \\
\hline 30 & $111^{\circ}$ & MAGAZINE LUÍZA S.A. & 107 & 32 & 139 \\
\hline 31 & $318^{\circ}$ & MAHLE METAL LEVE S.A. & 143 & 47 & 190 \\
\hline 32 & $219^{\circ}$ & MARFRIG ALIMENTOS S.A. & 227 & 18 & 245 \\
\hline 33 & $181^{\circ}$ & OI S.A. & 760 & 928 & 1.688 \\
\hline 34 & $22^{\circ}$ & PARANAPANEMA S.A. & 65 & 61 & 126 \\
\hline 35 & $340^{\circ}$ & SÃO MARTINHO S.A. & 117 & 21 & 138 \\
\hline 36 & $319^{\circ}$ & TIM CELULAR S.A. & 1.178 & 735 & 1.913 \\
\hline 37 & $21^{\circ}$ & USINAS SIDERÚR. MINAS GERAIS S.A. - USIMINAS & 711 & 682 & 1.393 \\
\hline 38 & $29^{\circ}$ & VALE S.A. & 1.621 & 1.059 & 2.680 \\
\hline 39 & $15^{\circ}$ & VIA VAREJO S.A. & 64 & 64 & 175 \\
\hline 40 & $239^{\circ}$ & WEG EQUIPAMENTOS ELÉTRICOS S.A. & 78 & 142
\end{tabular}

Fonte: Elaborado pelo autor

No quadro supra, a indicação "Polo Ativo" sinaliza que a parte afigura-se na condição de recorrente (apresentou o recurso) e, a indicação "Polo Passivo" sinaliza que a parte está na condição de recorrida, ou seja, o recurso foi apresentado pela parte ex adversa. É possível, ainda, que no mesmo feito, a parte encontre-se nas duas situações.

\subsection{Técnica para a coleta e análise de dados}

Os dados utilizados nessa pesquisa advém das demonstrações financeiras divulgadas pelas empresas sintetizadas na tabela 2.

Para todas as empresas listadas a consulta a tais demonstrações foi promovida mediante acesso ao sitio de relação com investidores de tais companhias na 
internet. Os endereços consultados estão relacionados, empresa a empresa, na Fonte de Consulta

Os dados consultados são secundários e, portanto, não se pode assumir responsabilidade quanto à validade dos mesmos.

Após o acesso ao sitio da internet, as demonstrações financeiras são disponibilizadas em arquivos do tipo ".pdf" que foram salvos para a análise. A partir de então, foram coletados os dados nas demonstrações consolidadas, alusivos ao exercício 2014.

Com exceção das companhias que atuam no segmento de açúcar e álcool, o exercício social compreendeu o período de $1^{\circ}$ de janeiro a 31 de dezembro de 2014 . Para as empresas excetuadas o exercício social foi de $1^{\circ}$ de abril de 2014 a 31 de março de 2015 .

Referente à tabulação e à análise estatística descritiva (média, mediana e desvio padrão) dos dados quantitativos colhidos nas demonstrações financeiras analisadas foi utilizado o Microsoft Excel ${ }^{\circledR}$.

Para as informações qualitativas contidas nas demonstrações financeiras, alusivas aos critérios de reconhecimento e mensuração das provisões, os textos foram segregados e, em seguida, sobre os mesmos foi aplicada análise de conteúdo.

\subsection{Variáveis examinadas}

A análise da evidenciação do passivo judicial trabalhista teve foco no risco financeiro oriundo do reconhecimento e da mensuração dos valores provisionados.

O primeiro ponto de exame, oriundo ao risco financeiro diz respeito à representatividade das provisões em relação às métricas contábeis e financeiras. A finalidade, nesse ponto, é aferir se a exigibilidade quanto ao pagamento do passivo judicial trabalhista pode comprometer o fluxo de caixa da companhia de modo a 
colocar a continuidade de suas atividades em risco.

Para tanto, foram estabelecidas relações entre o valor do passivo judicial trabalhista e o Caixa, o Capital Circulante Líquido e o EBITDA.

Em seguida, foi examinada a questão do fluxo (cronograma) de pagamentos eis que, em se tratando de análise de risco (em especial de liquidez) não é suficiente aferir os valores nominais mas, também, os momentos em que os desembolsos possam vir a ser exigidos. Compreende, nesse item, a eventual existência de classificação das provisões no passivo circulante e no passivo não circulante.

Conquanto apenas as perdas consideradas como prováveis contenham obrigatoriedade de provisionamento, promoveu-se, também, a análise quanto à evidenciação de perdas possíveis.

E, o gerenciamento do passivo judicial trabalhista possui outra lente de análise que é a quantidade de ações envolvidas. Assim ocorre porque o gerenciamento de um passivo no valor $X$ referente a uma dezena de ações é diferente do gerenciamento desse mesmo valor de passivo pulverizado em milhares de ações. Isso impacta as estratégias de acordo e da própria condução das ações, em relação a tempo de tramitação, interposição de recursos e valores envolvidos na administração dessa massa de dados.

Essa primeira etapa envolve aspectos, predominantemente, quantitativos e, onde possível, foi utilizada a estatística descritiva. O exame, a partir desse ponto, adentra ao aspecto textual e será promovido com análise de conteúdo para aferir se há evidenciação quanto à origem do passivo judicial trabalhista e quanto aos critérios utilizados para a mensuração das provisões efetuadas. 


\section{DAS ANÁLISES}

As análises tiveram início aferindo os valores provisionados pelas companhias examinadas as quais foram divididas em três grupos: provisões cíveis, provisões tributárias e provisões trabalhistas.

Considerando que as companhias possuem especificidades em suas operações, a divulgação das provisões não ocorre de modo idêntico. Há companhias que divulgam provisões ambientais e/ou regulatórias, em, função do segmento em que atuam. Outras agrupam provisões de menores valores sob a rubrica "outros". Em tais situações esses valores (ambientais, regulatórios e "outros") foram adicionados com as provisões tributárias.

O primeiro ponto de análise refere-se, então, à composição dos valores provisionados e à aferição de qual a relevância das provisões trabalhistas dentro do valor total provisionado em cada companhia. Os dados coletados estão compilados na tabela 3, apresentada a seguir:

Tabela 3 - Composição e representatividade das provisões

\begin{tabular}{|c|c|c|c|c|c|c|c|c|c|}
\hline \multirow{2}{*}{ Nome de Pregão } & \multirow[t]{2}{*}{$\begin{array}{c}\text { Qte. de } \\
\text { Empregs. }\end{array}$} & \multicolumn{2}{|c|}{ Provisão Cível } & \multicolumn{2}{|c|}{$\begin{array}{l}\text { Provisão } \\
\text { Tributária }\end{array}$} & \multicolumn{2}{|c|}{$\begin{array}{l}\text { Provisão } \\
\text { Trabalhista }\end{array}$} & \multicolumn{2}{|c|}{ Total de Provisões } \\
\hline & & (\$) & $(\%)$ & (\$) & $(\%)$ & (\$) & (\%) & (\$) & (\%) \\
\hline AES TIETE E & 1.635 & 10.498 & $21,8 \%$ & 16.381 & $34,0 \%$ & 21.245 & $44,1 \%$ & 48.124 & $100,0 \%$ \\
\hline ALPARGATAS & 18.999 & 4.189 & $10,9 \%$ & 6.731 & $17,5 \%$ & 27.519 & $71,6 \%$ & 38.439 & $100,0 \%$ \\
\hline AREZZO CO & 2.091 & 507 & $9,5 \%$ & 2.044 & $38,4 \%$ & 2.766 & $52,0 \%$ & 5.317 & $100,0 \%$ \\
\hline BRADESCO & 95.520 & 3.937 .591 & $28,4 \%$ & 7.221 .447 & $52,1 \%$ & 2.705 .363 & $19,5 \%$ & 13.864 .401 & $100,0 \%$ \\
\hline BRASIL & 111.628 & 5.772 .606 & $55,0 \%$ & 1.997 .160 & $19,0 \%$ & 2.735 .089 & $26,0 \%$ & 10.504 .606 & $100,0 \%$ \\
\hline BANRISUL & 11.636 & 98.020 & $10,9 \%$ & 601.940 & $66,7 \%$ & 202.520 & $22,4 \%$ & 902.480 & $100,0 \%$ \\
\hline BANCO PAN & 3.485 & 180.478 & $59,4 \%$ & 26.824 & $8,8 \%$ & 96.602 & $31,8 \%$ & 303.904 & $100,0 \%$ \\
\hline BIOSEV & 16.162 & 27.583 & $5,9 \%$ & 218.416 & $46,6 \%$ & 222.591 & $47,5 \%$ & 468.590 & $100,0 \%$ \\
\hline BRASKEM & 22.917 & 1.251 & $0,3 \%$ & 270.320 & $65,5 \%$ & 141.240 & $34,2 \%$ & 412.811 & $100,0 \%$ \\
\hline BRF SA & 105.887 & 57.359 & $4,8 \%$ & 797.950 & $67,3 \%$ & 330.424 & $27,9 \%$ & 1.185 .733 & $100,0 \%$ \\
\hline CELESC & 3.287 & 156.309 & $52,7 \%$ & 75.470 & $25,5 \%$ & 64.738 & $21,8 \%$ & 296.517 & $100,0 \%$ \\
\hline CESP & 7.922 & 282.932 & $37,5 \%$ & 149.518 & $19,8 \%$ & 322.525 & $42,7 \%$ & 754.975 & $100,0 \%$ \\
\hline P.ACUCAR-CBD & 161.311 & 231.000 & $17,2 \%$ & 589.000 & $43,8 \%$ & 524.000 & $39,0 \%$ & 1.344 .000 & $100,0 \%$ \\
\hline CEMIG & 922 & 2.233 .755 & $83,9 \%$ & 14.898 & $0,6 \%$ & 412.213 & $15,5 \%$ & 2.660 .866 & $100,0 \%$ \\
\hline
\end{tabular}




\begin{tabular}{|c|c|c|c|c|c|c|c|c|c|}
\hline \multirow{2}{*}{ Nome de Pregão } & \multirow[t]{2}{*}{\begin{tabular}{|c|} 
Qte. de \\
Empregs.
\end{tabular}} & \multicolumn{2}{|c|}{ Provisão Cível } & \multicolumn{2}{|c|}{$\begin{array}{l}\text { Provisão } \\
\text { Tributária }\end{array}$} & \multicolumn{2}{|c|}{$\begin{array}{l}\text { Provisão } \\
\text { Trabalhista }\end{array}$} & \multicolumn{2}{|c|}{ Total de Provisões } \\
\hline & & (\$) & (\%) & (\$) & $(\%)$ & (\$) & $(\%)$ & (\$) & (\%) \\
\hline CEEE-D & 2.784 & 117.985 & $45,0 \%$ & - & $0,0 \%$ & 143.990 & $55,0 \%$ & 261.975 & $100,0 \%$ \\
\hline CEEE-GT & 1.334 & 70.893 & $40,9 \%$ & 4.140 & $2,4 \%$ & 98.510 & $56,8 \%$ & 173.543 & $100,0 \%$ \\
\hline SABESP & 14.753 & 1.023 .894 & $66,4 \%$ & 281.958 & $18,3 \%$ & 235.466 & $15,3 \%$ & 1.541 .318 & $100,0 \%$ \\
\hline COPEL & 8.592 & 755.077 & $48,8 \%$ & 350.766 & $22,7 \%$ & 440.789 & $28,5 \%$ & 1.546 .632 & $100,0 \%$ \\
\hline CPFL ENERGIA & 9.136 & 172.564 & $35,2 \%$ & 194.033 & $39,5 \%$ & 124.261 & $25,3 \%$ & 490.858 & $100,0 \%$ \\
\hline ELETROPAULO & 6.152 & 32.323 & $6,9 \%$ & 183.545 & $39,3 \%$ & 251.747 & $53,8 \%$ & 467.615 & $100,0 \%$ \\
\hline FIBRIA & 4.004 & 27.361 & $9,1 \%$ & 100.604 & $33,3 \%$ & 174.179 & $57,6 \%$ & 302.144 & $100,0 \%$ \\
\hline GERDAU & 40.061 & 39.793 & $2,5 \%$ & 1.308 .087 & $83,0 \%$ & 228.475 & $14,5 \%$ & 1.576 .355 & $100,0 \%$ \\
\hline GOL & 16.875 & 55.097 & $54,0 \%$ & - & $0,0 \%$ & 46.996 & $46,0 \%$ & 102.093 & $100,0 \%$ \\
\hline ITAUUNIBANCO & 93.200 & 4.802 .187 & $28,2 \%$ & 6.626 .932 & $38,9 \%$ & 5.597 .552 & $32,9 \%$ & 17.026 .671 & $100,0 \%$ \\
\hline JBS & 216.693 & 78.261 & $11,1 \%$ & 386.479 & $54,8 \%$ & 241.104 & $34,2 \%$ & 705.844 & $100,0 \%$ \\
\hline JSL & 23.000 & 13.461 & $19,4 \%$ & 7.898 & $11,4 \%$ & 47.852 & $69,1 \%$ & 69.211 & $100,0 \%$ \\
\hline KLABIN S/A & 16.945 & 7.712 & $9,6 \%$ & 8.634 & $10,7 \%$ & 64.296 & $79,7 \%$ & 80.642 & $100,0 \%$ \\
\hline LIGHT S/A & 4.282 & 175.658 & $34,3 \%$ & 209.207 & $40,8 \%$ & 127.921 & $24,9 \%$ & 512.786 & $100,0 \%$ \\
\hline LOJAS RENNER & 16.900 & 14.974 & $29,8 \%$ & 26.259 & $52,2 \%$ & 9.024 & $18,0 \%$ & 50.257 & $100,0 \%$ \\
\hline MAGAZ LUIZA & 24.428 & 17.329 & $6,5 \%$ & 223.113 & $84,0 \%$ & 25.249 & $9,5 \%$ & 265.691 & $100,0 \%$ \\
\hline METAL LEVE & 9.456 & 38.626 & $16,3 \%$ & & $0,0 \%$ & 198.894 & $83,7 \%$ & 237.520 & $100,0 \%$ \\
\hline MARFRIG & 45.243 & 4.233 & $10,5 \%$ & 3.531 & $8,7 \%$ & 32.684 & $80,8 \%$ & 40.448 & $100,0 \%$ \\
\hline $\mathrm{Ol}$ & 18.295 & 3.444 .123 & $67,1 \%$ & 536.621 & $10,5 \%$ & 1.155 .024 & $22,5 \%$ & 5.131 .768 & $100,0 \%$ \\
\hline PARANAPANEMA & 2.700 & 18.516 & $9,6 \%$ & - & $0,0 \%$ & 175.152 & $90,4 \%$ & 193.668 & $100,0 \%$ \\
\hline SAO MARTINHO & 11.680 & 4.793 & $8,6 \%$ & 9.693 & $17,5 \%$ & 40.944 & $73,9 \%$ & 55.430 & $100,0 \%$ \\
\hline TIM PART SIA & 12.860 & 103.303 & $25,4 \%$ & 240.259 & $59,1 \%$ & 62.947 & $15,5 \%$ & 406.509 & $100,0 \%$ \\
\hline USIMINAS & 20.225 & 101.982 & $21,4 \%$ & 91.537 & $19,2 \%$ & 283.340 & $59,5 \%$ & 475.859 & $100,0 \%$ \\
\hline VALE & 76.531 & 311.000 & $9,1 \%$ & 1.218 .000 & $35,8 \%$ & 1.876 .000 & $55,1 \%$ & 3.405 .000 & $100,0 \%$ \\
\hline VIAVAREJO & 62.339 & 113.000 & $25,5 \%$ & 29.000 & $6,5 \%$ & 301.000 & $67,9 \%$ & 443.000 & $100,0 \%$ \\
\hline WEG & 29.572 & 73.747 & $28,5 \%$ & 93.321 & $36,1 \%$ & 91.781 & $35,5 \%$ & 258.849 & $100,0 \%$ \\
\hline Média & & & $26,7 \%$ & & $30,9 \%$ & & $42,6 \%$ & & \\
\hline Desvio Padrão & & & $21,0 \%$ & & $23,8 \%$ & & $22,3 \%$ & & \\
\hline Mediana & & & $21,6 \%$ & & $29,4 \%$ & & $37,2 \%$ & & \\
\hline Menor & & & $0,3 \%$ & & $0,0 \%$ & & $9,5 \%$ & & \\
\hline Maior & & & $83,9 \%$ & & $84,0 \%$ & & $90,4 \%$ & & \\
\hline Intervalo & & & $\mid 83,6 \%$ & & $84,0 \%$ & & $80,9 \%$ & & \\
\hline
\end{tabular}

Fonte: elaborado pelo autor

$\mathrm{Na}$ tabela supra verifica-se que, em media, as provisões trabalhistas correspondem a $42,6 \%$ do valor total provisionado. De outra parte, em 15 das 40 empresas analisadas, o valor provisionado para o passivo judicial trabalhista é maior que 50\% do valor total provisionado, o que denota a importância desse tipo de provisão. 


\subsection{Análise da representatividade}

Nesse item busca-se aferir as relações existentes entre os valores provisionados pelas companhias para pagamento do passivo judicial trabalhista com indicadores e métricas contábeis associados à capacidade de pagamento no curto prazo: caixa, capital circulante líquido e EBITDA. As relações apuradas estão demonstradas na tabela 4, apresentada a seguir:

Tabela 4 - Relações entre a provisão trabalhista e o caixa, o CCL e o EBITDA

\begin{tabular}{|c|c|c|c|c|c|c|c|}
\hline \multirow{2}{*}{ Nome de Pregão } & \multirow{2}{*}{$\begin{array}{r}\begin{array}{c}\text { Provisão } \\
\text { Trabalhista }\end{array} \\
\text { (\$) } \\
\end{array}$} & \multicolumn{2}{|c|}{ Caixa } & \multicolumn{2}{|c|}{$\begin{array}{l}\text { Capital Circulante } \\
\text { Líquido }\end{array}$} & \multicolumn{2}{|c|}{ EBITDA } \\
\hline & & (\$) & (\%) & (\$) & $(\%)$ & (\$) & (\%) \\
\hline AES TIETE E & 21.245 & 58.641 & $36,2 \%$ & $(521.773)$ & $-4,1 \%$ & 401.400 & $5,3 \%$ \\
\hline ALPARGATAS & 27.519 & 316.610 & $8,7 \%$ & 1.143 .232 & $2,4 \%$ & 153.100 & $18,0 \%$ \\
\hline AREZZO CO & 2.766 & 10.831 & $25,5 \%$ & 439.850 & $0,6 \%$ & 161.300 & $1,7 \%$ \\
\hline BRADESCO & 2.705 .363 & 65.430 .300 & $4,1 \%$ & $(59.585 .320)$ & $-4,5 \%$ & não calc & não calc \\
\hline BRASIL & 2.735 .089 & 13.786 .585 & $19,8 \%$ & $(86.397 .749)$ & $-3,2 \%$ & não calc & não calc \\
\hline BANRISUL & 202.520 & 797.517 & $25,4 \%$ & $(2.165 .299)$ & $-9,4 \%$ & não calc & não calc \\
\hline BANCO PAN & 96.602 & 47.298 & $204,2 \%$ & $(4.474 .900)$ & $-2,2 \%$ & não calc & não calc \\
\hline BIOSEV & 222.591 & 1.946.971 & $11,4 \%$ & (188.265) & $-118,2 \%$ & 1.335 .402 & $16,7 \%$ \\
\hline BRASKEM & 141.240 & 3.993.359 & $3,5 \%$ & 677.907 & $20,8 \%$ & 5.620 .260 & $2,5 \%$ \\
\hline BRF SA & 330.424 & 6.006 .942 & $5,5 \%$ & 7.919.119 & $4,2 \%$ & 4.897 .000 & $6,7 \%$ \\
\hline CELESC & 64.738 & 449.789 & $14,4 \%$ & 3.434 .271 & $1,9 \%$ & 1.003 .218 & $6,5 \%$ \\
\hline CESP & 322.525 & 887.143 & $36,4 \%$ & $(3.568 .939)$ & $-9,0 \%$ & 6.382 & $5053,7 \%$ \\
\hline P.ACUCAR-CBD & 524.000 & 11.149 .000 & $4,7 \%$ & 285.000 & $183,9 \%$ & 4.929 .635 & $10,6 \%$ \\
\hline CEMIG & 412.213 & 5.796 & $7112,0 \%$ & 746.153 & $55,2 \%$ & 4.017.287 & $10,3 \%$ \\
\hline CEEE-D & 143.990 & 42.715 & $337,1 \%$ & (355.098) & $-40,5 \%$ & $(325.979)$ & $-44,2 \%$ \\
\hline CEEE-GT & 98.510 & 73.972 & $133,2 \%$ & 360.263 & $27,3 \%$ & $(473.981)$ & $-20,8 \%$ \\
\hline SABESP & 235.466 & 1.722 .991 & $13,7 \%$ & $(265.131)$ & $-88,8 \%$ & 2.918 .700 & $8,1 \%$ \\
\hline COPEL & 440.789 & 740.131 & $59,6 \%$ & 1.162 .783 & $37,9 \%$ & 2.339.857 & $18,8 \%$ \\
\hline CPFL ENERGIA & 124.261 & 4.357 .455 & $2,9 \%$ & 1.797 .600 & $6,9 \%$ & 3.760 .903 & $3,3 \%$ \\
\hline ELETROPAULO & 251.747 & 181.260 & $138,9 \%$ & 7.727 & $3258,0 \%$ & 476.100 & $52,9 \%$ \\
\hline FIBRIA & 174.179 & 461.067 & $37,8 \%$ & 1.161 .947 & $15,0 \%$ & 2.791 .000 & $6,2 \%$ \\
\hline GERDAU & 228.475 & 3.049 .971 & $7,5 \%$ & 12.909 .943 & $1,8 \%$ & 4.828 .000 & $4,7 \%$ \\
\hline
\end{tabular}




\begin{tabular}{|c|c|c|c|c|c|c|c|}
\hline \multirow{2}{*}{ Nome de Pregão } & \multirow{2}{*}{$\begin{array}{r}\begin{array}{c}\text { Provisão } \\
\text { Trabalhista }\end{array} \\
\text { (\$) }\end{array}$} & \multicolumn{2}{|c|}{ Caixa } & \multicolumn{2}{|c|}{$\begin{array}{l}\text { Capital Circulante } \\
\text { Líquido }\end{array}$} & \multicolumn{2}{|c|}{ EBITDA } \\
\hline & & (\$) & (\%) & (\$) & (\%) & (\$) & (\%) \\
\hline GOL & 46.996 & 1.898 .773 & $2,5 \%$ & $(1.226 .448)$ & $-3,8 \%$ & 1.812 .810 & $2,6 \%$ \\
\hline ITAUUNIBANCO & 5.597 .552 & 17.527 .249 & $31,9 \%$ & 208.573 .853 & $2,7 \%$ & não calc & não calc \\
\hline JBS & 241.104 & 8.368 .528 & $2,9 \%$ & 12.674 .231 & $1,9 \%$ & 11.090 .000 & $2,2 \%$ \\
\hline JSL & 47.852 & 2.854.393 & $1,7 \%$ & 5.617 .955 & $0,9 \%$ & 869.000 & $5,5 \%$ \\
\hline KLABIN S/A & 64.296 & 5.245 .833 & $1,2 \%$ & 5.380 .803 & $1,2 \%$ & 1.718 .000 & $3,7 \%$ \\
\hline LIGHT S/A & 127.921 & 401.138 & $31,9 \%$ & 30.480 & $419,7 \%$ & 1.809 .700 & $7,1 \%$ \\
\hline LOJAS RENNER & 9.024 & 834.340 & $1,1 \%$ & 1.461 .981 & $0,6 \%$ & 1.014 .800 & $0,9 \%$ \\
\hline MAGAZ LUIZA & 25.249 & 412.170 & $6,1 \%$ & 564.474 & $4,5 \%$ & 605.300 & $4,2 \%$ \\
\hline METAL LEVE & 198.894 & 287.282 & $69,2 \%$ & 496.012 & $40,1 \%$ & 398.000 & $50,0 \%$ \\
\hline MARFRIG & 32.684 & 1.091 .685 & $3,0 \%$ & 3.706 .052 & $0,9 \%$ & 1.685 .900 & $1,9 \%$ \\
\hline $\mathrm{OI}$ & 1.155 .024 & 2.449 .206 & $47,2 \%$ & 6.729 .963 & $17,2 \%$ & 10.210 .000 & $11,3 \%$ \\
\hline PARANAPANEMA & 175.152 & 276.872 & $63,3 \%$ & 117.554 & $149,0 \%$ & 358.327 & $48,9 \%$ \\
\hline SAO MARTINHO & 40.944 & 1.020 .112 & $4,0 \%$ & 329.707 & $12,4 \%$ & 1.091 .592 & $3,8 \%$ \\
\hline TIM PART S/A & 62.947 & 5.232 .992 & $1,2 \%$ & 2.051 .159 & $3,1 \%$ & 5.538 .000 & $1,1 \%$ \\
\hline USIMINAS & 283.340 & 2.109 .812 & $13,4 \%$ & 3.475 .785 & $8,2 \%$ & 1.863 .071 & $15,2 \%$ \\
\hline VALE & 1.876 .000 & 10.555 .000 & $17,8 \%$ & 15.857 .000 & $11,8 \%$ & 35.537 .700 & $5,3 \%$ \\
\hline VIAVAREJO & 301.000 & 4.448 .000 & $6,8 \%$ & 998.000 & $30,2 \%$ & 2.270 .000 & $13,3 \%$ \\
\hline WEG & 91.781 & 3.328 .015 & $2,8 \%$ & 4.717.372 & $1,9 \%$ & 1.344 .800 & $6,8 \%$ \\
\hline Média & & & $213,8 \%$ & & $101,0 \%$ & & $152,7 \%$ \\
\hline Desvio Padrão & & & $1120,5 \%$ & & $518,2 \%$ & & $852,9 \%$ \\
\hline Mediana & & & $13,5 \%$ & & $2,5 \%$ & & $6,2 \%$ \\
\hline Menor & & & $1,1 \%$ & & $-118,2 \%$ & & $-44,2 \%$ \\
\hline Maior & & & $7112,0 \%$ & & $3258,0 \%$ & & $5053,7 \%$ \\
\hline Intervalo & & & $7110,9 \%$ & & $3376,3 \%$ & & $5097,8 \%$ \\
\hline
\end{tabular}

Fonte: elaborado pelo autor

No que concerne à relação da provisão para pagamento de passivo judicial trabalhista e o saldo de caixa, não se ignora aqui, que as companhias possam ter recursos em aplicações financeiras, não considerados como caixa (ou equivalentes), passíveis de resgate e conversão em caixa.

Contudo, a ausência de recursos em tal conta, suficientes para pagamento de um passivo não provisionado, provisionado a menor ou com desembolso em data 
anterior à prevista, pode comprometer o fluxo de caixa e, em especial o capital de giro, trazendo dificuldades financeiras (ainda que momentâneas) para a companhia.

$\mathrm{E}$, aqui volta à tona a questão da quantidade de ações que dá origem ao passivo judicial trabalhista eis que no caso de ações massificadas a tendência é que os valores individuais de cada ação sejam menores e, em conseqüência, o risco de que uma ação (particularmente considerada) provoque comprometimento ao fluxo de caixa, é menor.

\subsubsection{Relação com o caixa}

Atinente às relações com o caixa a tabela 4 evidencia que, em média, as provisões correspondem a $213,8 \%$ do saldo em caixa, porém, com grande dispersão dos valores, o que se confirma pelo desvio padrão de 1.120,5\% (5 vezes a média).

Essa dispersão foi causada pelo valor do saldo do caixa da CEMIG (R\$ 5.796 mil) que gerou uma relação percentual de 7.112,0\%, o que comprometeu a media geral. Excluindo-se a CEMIG da apuração a média é reduzida para 36,9\% e os dados apresentam maior uniformidade (desvio padrão de 65,51\%).

A considerar-se a média de 36,9\% poder-se-ia dizer que, para cada $R \$ 1,00$ provisionado a companhia possui $\mathrm{R} \$ 2,71$ em caixa.

Há casos, contudo, em que o valor provisionado é maior que os saldos de caixa e, em tal situação estão o Banco Pan (204,2\%), a CEMIG (7.112,0\%), a CEEE-D $(337,1 \%)$, a CEEE-GT $(133,2 \%)$ e a ELETROPAULO (138,9\%). De 5 casos, 4 pertencem ao setor elétrico.

Em outro extremo, há casos em que os valores provisionados são irrelevantes em relação aos saldos de caixa, como ocorre com o Bradesco (4,1\%), a Braskem (3,5\%), o Grupo Pão de Açúcar (4,7\%), a CPFL (2,9\%), a GOL (2,5\%), a JBS (2,9\%), a JSL (1,7\%), a Klabin (1,2\%), a Renner (1,1\%), a Marfrig (3,0\%), a São Martinho $(4,0 \%)$, a TIM (1,2\%) e a Weg (2,8\%). Todas com equivalências inferiores a 5,0\%. 


\subsubsection{Relação com o Capital Circulante Líquido}

O caixa e os demais itens do ativo circulante não se destinam, exclusivamente, ao pagamento das provisões alusivas ao passivo judicial trabalhista eis que, no curso normal de suas operações as companhias tem um conjunto de obrigações com fornecedores, com pessoal e com o fisco, dentre outras. Assim, passou-se a analisar as relações das provisões com o Capital Circulante Líquido (CCL).

E, a primeira observação que se faz, nesse ponto, é que várias das companhias analisadas apresentam valor negativo para o CCL e tal aspecto, por si só, já denota sinais de dificuldade em relação ao adimplemento de obrigações de curto prazo e ao capital de giro. Para tais empresas, desembolsos não provisionados ou exigíveis com antecipação (por determinação judicial, por exemplo), podem elevar o grau de dificuldades.

Em tal situação estão: AES Tiete, Biosev, CESP, CEEE-D, Sabesp e Gol. As instituições bancárias não foram incluídas nesse rol em função da particularidade de suas operações.

Há, também, empresas com CCL baixo (próximo a zero) que acabam por distorcer o resultado. Aqui estão a Eletropaulo e a Light.

$\mathrm{Na}$ média geral a equivalência das provisões para pagamento do passivo judicial trabalhista corresponde a $101,0 \%$ do CCL, com desvio padrão de 518,2\% (evidenciando a disparidade dos números).

Excluindo-se as empresas com CCL negativo e aquelas com CCL baixo (acima destacadas), a equivalência média passa a ser de $23,0 \%$ com desvio padrão de $43,2 \%$.

Para esse caso, com essa equivalência média, a companhia teria $\mathrm{R} \$ 4,35$ de $\mathrm{CCL}$ para cada $R \$ 1,00$ provisionado, sinalizando que os pagamentos dar-se-iam sem comprometimento de suas atividades operacionais. 


\subsubsection{Relação com o EBITDA}

O EBITDA (Earnings Before Interest, Taxes, Depreciation and Amortization) também conhecido como LAJIDA é uma métrica contábil que representa o lucro antes de juros, impostos, depreciação e amortização. É uma medida de aferição do resultado das atividades operacionais de determinada companhia eis que não considera resultados não operacionais (financeiros, tributários, depreciação e amortização).

Esse é um indicador que, se isoladamente considerado, é analisado sob o prisma de quanto maior seu número melhor.

Não se calcula esse indicador para as instituições financeiras e, por tal motivo, os bancos constantes na amostra não foram incluídos em tal análise.

Da amostra há duas empresas com EBITDA negativo, quais sejam a CEEE-D e a CEEE-GT. Há, ainda, comportamento diferenciado para a CESP que, em função do valor baixo para o EBITDA (R\$ 6.382 mil) apresentou relação percentual com a provisão para pagamento do passivo judicial trabalhista de 5.053,7\%.

Então, no geral, a média foi de 152,7\% com desvio padrão de 852,9\%. Efetuando-se ajuste no cálculo, com a exclusão do outlier (CESP) e das empresas com EBITDA negativo, a média é reduzida para 11,1\% com desvio padrão de 13,8\%.

Nessa situação, as empresas analisadas não teriam dificuldades para efetuar o pagamento de seu passivo judicial trabalhista eis que, para cada $R \$ 1,00$ provisionado, suas atividades operacionais geram $R \$ 8,99$.

\subsection{Análise do reconhecimento e da mensuração}

Nesse item da análise busca-se aferir como as provisões são constituídas e, para tanto, examina-se a origem do passivo judicial trabalhista, os critérios de mensuração e atribuição de valor para cada ação judicial objeto de provisionamento. 
De modo complementar, busca-se aferir se há um cronograma para pagamento do passivo judicial trabalhista e quantas ações há em andamento e quantas foram objeto de provisionamento.

As análises serão desenvolvidas, sempre que possível, apresentando um quadro das práticas comuns (consideradas como básicas ou mínimas) e outro consignando as melhores práticas constatadas junto às empresas examinadas.

\subsubsection{Da origem do passivo judicial trabalhista}

Conhecer a origem do passivo judicial trabalhista pode auxiliar na análise dos riscos no que concerne à gestão de pessoas e, bem assim, aferir se eventual valor provisionado decorre de uma situação pontual (o fechamento de uma unidade operacional ou a incorporação de uma empresa, por exemplo) ou se é uma prática recorrente.

Nas demonstrações financeiras analisadas constatou-se que a origem das ações, no mais das vezes, vem apresentada de modo sucinto, sem maior detalhamento, com mera informação de que tratam-se de processos movidos por ex-empregados com listagem de algumas verbas trabalhistas (com róis mais ou menos amplos).

Esse tipo de indicação, contudo, é pouco efetivo, porque não diferencia a companhia e denota uma certa situação de "normalidade" em que nada há de especial.

Nesse sentido estão, por exemplo, as demonstrações da Arezzo, da Mahle e da Weg, nas quais AA origem do passivo judicial trabalhista foi evidenciada do modo consignado no quadro 2.

Em tais situações a indicação é de uma prática recorrente das companhias em relação à gestão de pessoas e à interposição de ações judiciais, não cabendo ao tema maiores explicações por parte das referidas companhias. 


\begin{tabular}{|c|c|c|}
\hline \multicolumn{3}{|c|}{$\begin{array}{l}\text { Práticas comuns de evidenciação: ausência de detalhamento da origem do passivo } \\
\text { judicial }\end{array}$} \\
\hline Arezzo & Mahle & Weg \\
\hline $\begin{array}{l}\text { A Companhia e suas controladas } \\
\text { são partes em processos } \\
\text { trabalhistas relacionados, } \\
\text { principalmente, ao pagamento de } \\
\text { horas extras e seus respectivos } \\
\text { encargos sociais, adicionais de } \\
\text { insalubridade e periculosidade, } \\
\text { equiparação salarial e integração } \\
\text { de verbas na remuneração. }\end{array}$ & $\begin{array}{l}\text { As provisões trabalhistas } \\
\text { consistem, principalmente, } \\
\text { de reclamações por ex- } \\
\text { empregados vinculadas às } \\
\text { verbas decorrentes da } \\
\text { relação de emprego e a } \\
\text { vários pleitos indenizatórios. }\end{array}$ & $\begin{array}{l}\text { A Companhia e suas } \\
\text { controladas são acionadas em } \\
\text { reclamatórias trabalhistas } \\
\text { envolvendo principalmente } \\
\text { discussões sobre insalubridade, } \\
\text { periculosidade, entre outros. }\end{array}$ \\
\hline
\end{tabular}

Quadro 2 - Práticas comuns de evidenciação: ausência de detalhamento da origem do passivo judicial

De outra parte há empresas que detalham, efetivamente, a origem das ações trabalhistas e, nesse caso, destacam-se a Ol e a TIM que, em suas notas explicativas informaram o quanto sintetizado no quadro 3.

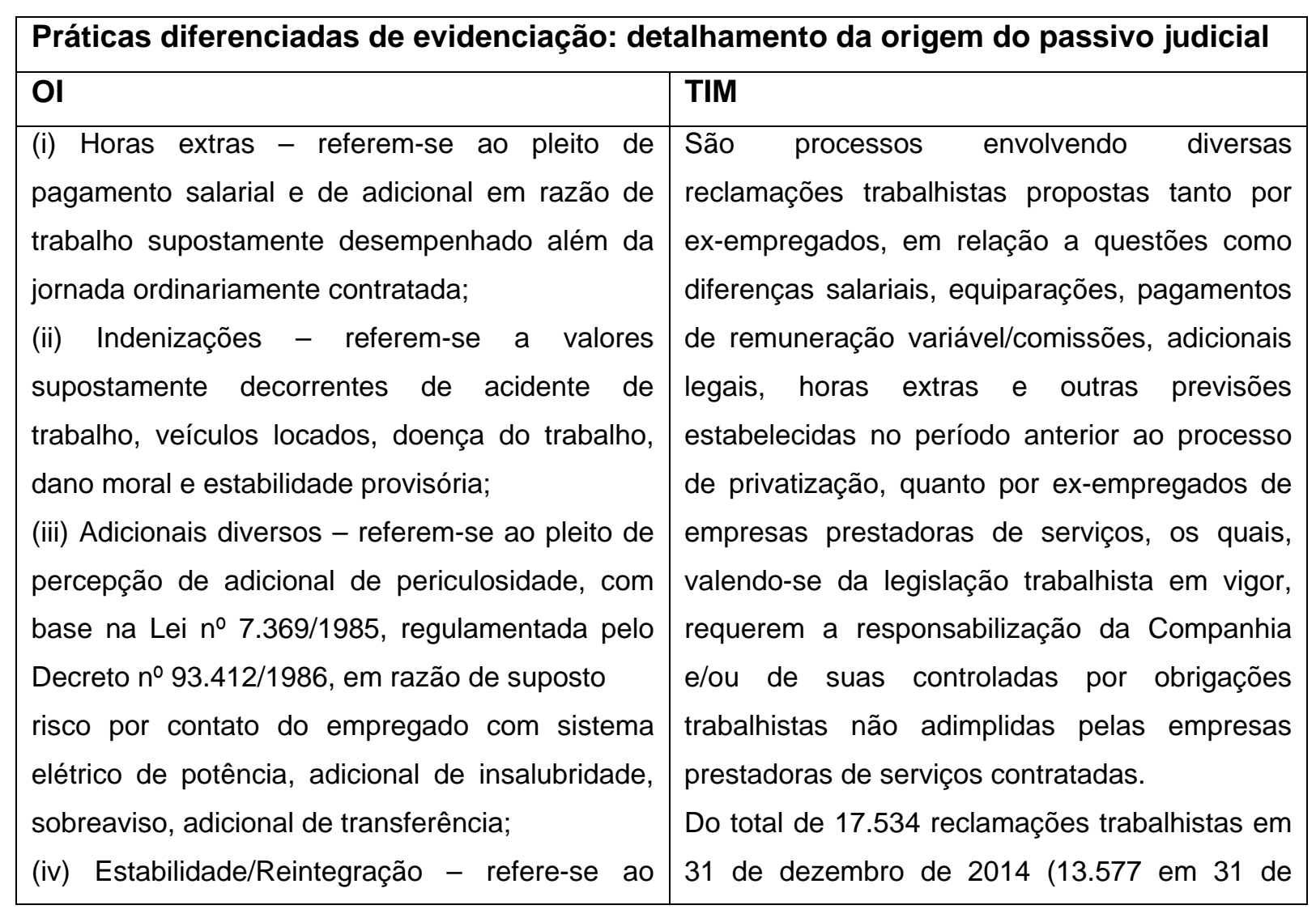


pleito decorrente de suposta inobservância de condição especial do empregado, garantidora da impossibilidade de rescisão de contrato de trabalho sem justa causa;

(v) Complemento de aposentadoria - diferenças supostamente devidas no salário de benefício referente a verbas trabalhistas;

(vi) Diferenças salariais e reflexos - referem-se, principalmente, a pedidos de incidência de aumentos salariais decorrentes de negociações sindicais supostamente descumpridas. Já os reflexos dizem respeito à repercussão do aumento salarial supostamente devido nas demais verbas calculadas com base no salário do empregado;

(vii) Honorários advocatícios/periciais - parcelas a pagar nos processos aos advogados que patrocinam os reclamantes, bem como os peritos nomeados pelo Juízo, quando faz-se necessário, para a instrução processual, de prova técnica pericial;

(viii) Verbas rescisórias - referem-se a verbas supostamente não adimplidas na rescisão contratual ou suas diferenças;

(ix) Multas trabalhistas - valores decorrentes do atraso ou não pagamento de determinadas verbas do contrato de trabalho, nos prazos previstos nas legislações vigentes e acordos e convenções coletivas;

(x) Complemento de multa FGTS - decorrente de expurgos inflacionários, refere-se a pedidos de complementação da indenização da multa de FGTS, em razão da recomposição das contas desse fundo por expurgos inflacionários.

A Companhia ingressou com ação judicial contra a Caixa Econômica Federal, no intuito de assegurar o ressarcimento de todos os valores que forem pagos a esse título; dezembro de 2013), movidas contra a Companhia e suas controladas, a maioria refere-se a demandas que envolvem exempregados de prestadores de serviços.

Outra parcela significativa do contingenciamento existente diz respeito a processos de reestruturação organizacional, dos quais se destacam o encerramento das atividades dos Centros de Relacionamento com o Cliente (call center) das cidades de Fortaleza, Salvador e Belo Horizonte, que resultaram no desligamento de aproximadamente 800 colaboradores próprios e terceirizados. Em 31 de dezembro de 2014, o provisionamento destas causas totaliza $\mathrm{R} \$ 15.235$ (R\$19.371 em 31 de dezembro de 2013).

Quadro 3 - Práticas diferenciadas de evidenciação: detalhamento da origem do passivo judicial 
Para o caso da TIM há indicação de um evento (reestruturação organizacional) do qual decorreu o encerramento das atividades dos Centros de Relacionamento com o Cliente (call center) das cidades de Fortaleza, Salvador e Belo Horizonte, que resultou no desligamento de aproximadamente 800 colaboradores próprios e terceirizados.

Tal informação é relevante porque consigna um aspecto pontual, cuja repetição nos exercícios seguintes é anormal.

Para o caso da OI, há detalhamento das verbas que deram origem ao passivo judicial trabalhista, em nível acessível aos não operadores do Direito e, bem assim, há menção quanto à interposição de ação face à Caixa Econômica Federal com a finalidade de obter ressarcimento dos valores eventualmente desembolsados para adimplir condenações alusivas às diferenças de juros e atualização monetária do FGTS (JAM/CEF) em função de expurgos inflacionários.

\subsubsection{Da forma de constituição das provisões}

Nesse ponto da análise busca-se examinar quais são os critérios utilizados pelas companhias para a atribuição de valor para as ações que foram classificadas na condição de perda provável.

Dentre vários critérios possíveis, cabe destacar que as provisões podem ser constituídas assim:

- histórico de desembolsos passados para ações similares;

- estimativa de desembolso efetivo futuro (análise caso a caso);

- valor médio (valor total de desembolso em um período dividido pela quantidade de ações adimplidas);

- valor atual do risco, em função da fase processual da lide. 
A maior parte das empresas analisadas não indica qual o efetivo critério utilizado para a constituição das provisões, limitando-se ao uso de expressões genéricas e referindo-se ao uso da opinião de seus consultores legais.

Nessa situação estão, por exemplo, a Fibia, a Gerdau e o Magazine Luiza, como demonstrado no quadro 4.

\begin{tabular}{|l|l|l|l|}
\hline \multicolumn{2}{|c|}{$\begin{array}{l}\text { Práticas comuns de evidenciação: ausência de detalhamento quanto à forma de } \\
\text { constituição das provisões para adimplemento do passivo judicial trabalhista }\end{array}$} \\
\hline Fibia & Gerdau & Magazine Luiza \\
\hline As provisões para contingências, & A provisão foi constituída & A provisão para riscos \\
constituídas para fazer face a & considerando o julgamento & tributários, cíveis e trabalhistas \\
potenciais perdas decorrentes & dos assessores legais e da & é constituída com base em \\
dos processos em curso, são & Administração para os & pareceres jurídicos e avaliação \\
estabelecidas e atualizadas com & processos cuja expectativa de & da Administração sobre os \\
base na avaliação da da & perda foi avaliada como & processos conhecidos na data \\
Administração, fundamentada & provável, sendo suficiente & do balanço patrimonial, para \\
na opinião de seus assessores & para fazer face às perdas & $\begin{array}{l}\text { os riscos considerados } \\
\text { prováveis de perda }\end{array}$ \\
legais. & esperadas &
\end{tabular}

Quadro 4 - Práticas comuns de evidenciação: ausência de detalhamento quanto à forma de constituição das provisões para adimplemento do passivo judicial trabalhista

As empresas consignadas, por exemplo, no quadro supra não indicam, de modo objetivo, como as provisões foram constituídas. Assim é que não há menção ao efetivo critério utilizado, ainda que por seus assessores legais.

Há, porém, casos de companhias que explicitam os critérios utilizados para a constituição de suas provisões e que podem ser inseridas no rol de boas práticas. Nesse conjunto, por exemplo, estão as notas explicativas do Bradesco, do Banco Pan e da Oi, sintetizadas no quadro 5, onde consta: 


\begin{tabular}{|c|c|c|}
\hline \multicolumn{3}{|c|}{$\begin{array}{l}\text { Práticas diferenciadas de evidenciação: detalhamento dos critérios utilizados para a } \\
\text { constituição das provisões para adimplemento do passivo judicial trabalhista }\end{array}$} \\
\hline BRADESCO & BANCO PAN & OI \\
\hline  & $\begin{array}{l}\text { Todos os processos } \\
\text { trabalhistas são geridos } \\
\text { individualmente por meio de } \\
\text { sistema informatizado. A } \\
\text { provisão é constituída } \\
\text { individualmente, de acordo } \\
\text { com a situação do processo e } \\
\text { o efetivo risco de perda. } \\
\text { Os processos com decisão } \\
\text { judicial desfavorável têm } \\
\text { provisão associada } \\
\text { correspondente ao valor } \\
\text { efetivo da referida decisão, } \\
\text { devidamente liquidados. }\end{array}$ & $\begin{array}{l}\text { Em 2013, a Administração } \\
\text { revisou a metodologia de } \\
\text { apuração das provisões para } \\
\text { perdas em processos } \\
\text { trabalhistas incluindo técnicas } \\
\text { estatísticas, em função de } \\
\text { maior experiência acumulada } \\
\text { no assunto. A mudança de } \\
\text { estimativa gerou uma reversão } \\
\text { no montante de } \mathrm{R} \$ 163.474 \text { na } \\
\text { controladora e } \mathrm{R} \$ 315.648 \text { no } \\
\text { consolidado. }\end{array}$ \\
\hline
\end{tabular}

Quadro 5 - Práticas diferenciadas de evidenciação: detalhamento dos critérios utilizados para a constituição das provisões para adimplemento do passivo judicial trabalhista

O Banco Bradesco explicita que, para ações similares considera o valor médio apurado dos pagamentos efetuados nas reclamações trabalhistas encerradas nos últimos 12 meses e, para as ações oriundas de bancos adquiridos utiliza o histórico de perda recente.

O Banco Pan, por seu turno, informa adotar critério de análise individual das ações e 
que, havendo decisão desfavorável, promove a liquidação do valor (apuração do valor devido) e o provisiona.

A OI menciona tratar os dados históricos com ferramentas estatísticas de modo a obter os valores a provisionar.

Dessas três empresas destacadas com boas práticas quanto à evidenciação do critério utilizado para a constituição das provisões trabalhistas, foram identificados três critérios distintos (media, caso a caso e estatística).

E, a questão não é de indicar qual critério é melhor, mas sim de aferir qual é o critério utilizado pela companhia, podendo, inclusive, ser qualquer outro que não um dos supra apontados. O que se critica é não conhecer o critério.

\subsubsection{Da quantidade de ações}

Conhecer a quantidade de ações judiciais de uma companhia é relevante para que se possa ampliar a análise do risco envolvido com o passivo judicial trabalhista.

Ações pulverizadas e com baixo valor individual tendem a originar menores riscos, eis que a possibilidade de acordos e de parcelamentos é maior, já que o impacto (individual) no fluxo de caixa da companhia é ínfimo.

Já, quando há pequena quantidade de ações, com predominância de ações coletivas, substituição processual ou ação civil pública esse controle sobre acordos e parcelamentos é menor, requerendo maior atenção da companhia porque, em fase de execução os valores envolvidos podem ser muito relevantes.

Nessa situação está a ação civil pública movida pelo Ministério Público do Trabalho da $15^{a}$ Região contra a Raizen e a Basf em que a condenação foi na ordem de $\mathrm{R} \$$ 
1,1 bilhão $^{44}$. Assim:

O presidente do Tribunal Superior do Trabalho, ministro João Oreste Dalazen, concedeu parcialmente pedido de efeito suspensivo formulado pela Raízen Combustíveis S.A. (Shell) e pela BASF S. A. para sustar a obrigação das empresas de depositar ou garantir o valor de indenização por dano moral coletivo fixado pela Vara do Trabalho de Paulínia, estimado em $\mathrm{R} \$ 1,1$ bilhão, até o julgamento, pelo TST, do mérito de recurso contra a condenação, imposta pela Justiça do Trabalho da $15^{a}$ Região (Campinas/SP). A decisão, porém, preserva o cumprimento da sentença quanto à obrigação das empresas de custear o tratamento médico das vítimas de contaminação por elementos químicos na antiga fábrica da Shell em Paulínia (SP).

Então, a mera análise do valor provisionado pode não ser suficiente, tendo em vista a possibilidade de ocorrência de vieses como o supra apontado.

$\mathrm{Na}$ presente análise foram consideradas 40 empresas e, nas notas explicativas dessas companhias constatou-se que, tão somente 8 (20\%) apresentam a quantidade de ações que foram objeto de provisionamento.

As empresas que divulgaram e a forma de divulgação, consoante sinteizado no quadro 6, foram as seguintes:

44 Fonte: Tribunal Superior do Trabalho. Disponível em http://www.tst.jus.br/busca-denoticias?p_p_id=buscanoticia_WAR_buscanoticiasportlet_INSTANCE_xI8Y\&p_p_lifecycle=0\&p_p_

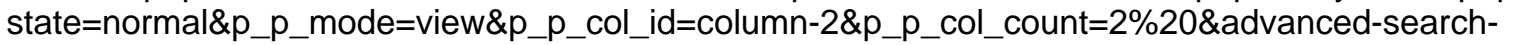
display=yes\%20\&articleld $=2109064 \% 20 \&$ version $=1.4 \% 20 \&$ groupld $=10157 \% 20 \&$ entry ClassPK $=210$ 9066 


\begin{tabular}{|c|c|}
\hline \multicolumn{2}{|c|}{$\begin{array}{l}\text { Práticas diferenciadas de evidenciação: detalhamento dos critérios utilizados para a } \\
\text { constituição das provisões para adimplemento do passivo judicial trabalhista }\end{array}$} \\
\hline Empresa & Evidenciação \\
\hline BRASKEM & $\begin{array}{l}\text { A provisão, em } 31 \text { de dezembro de } 2014 \text {, corresponde a } 350 \text { processos de } \\
\text { natureza trabalhista, incluindo casos de saúde ocupacional e segurança (2013 } \\
\text { - } 358 \text { processos) }\end{array}$ \\
\hline CESP & $\begin{array}{l}\text { Em } 31 \text { de dezembro de } 2014 \text {, as reclamações trabalhistas movidas contra a } \\
\text { CESP montavam a R } \$ 880.487 \text {. A CESP mantém provisões registradas para } \\
\text { enfrentar eventuais obrigações no montante de } \mathrm{R} \$ 412.213 \text { representadas por } \\
712 \text { ações judiciais. } \\
\text { A Companhia mantém depósitos judiciais em garantia de processos, da ordem } \\
\text { de } \mathrm{R} \$ 53.620 \text {. } \\
\text { A CESP é ré em } 45 \text { processos, cujo risco de perda é avaliado como provável, } \\
\text { relacionados à insalubridade/periculosidade, que totalizam } \mathrm{R} \$ 237.613 \text {. O } \\
\text { restante dos processos refere-se a diversas ações cuja totalidade é de } \mathrm{R} \$ \\
174.600 \text { associados a } 667 \text { ações judiciais. } \\
\text { Os processos trabalhistas com expectativa de perda possível totalizam } \mathrm{R} \$ \\
271.247 \text { correspondentes a } 975 \text { processos, sendo } 23 \text { destes relacionados à } \\
\text { Lei Estadual no. } 4.819 / 58 \text { que tratam de ações cujos reclamantes pleiteiam } \\
\text { principalmente: (i) transferência da folha de pagamento diretamente da } \\
\text { Fazenda do Estado de São Paulo; (ii) diferença de complementação de } \\
\text { aposentadoria; (iii) devolução do desconto de PSAP; e (iv) devolução do } \\
\text { desconto previdenciário (11\%) decorrente da EC } n^{\circ} \text {. } 20 / 98 \text {, no montante de } \mathrm{R} \$ \\
51.385 \text {. O valor remanescente, de } \mathrm{R} \$ 219.862 \text {, corresponde a } 952 \text { processos. }\end{array}$ \\
\hline ELETROPAULO & $\begin{array}{l}\text { A Companhia é demandada por empregados e ex-empregados próprios e } \\
\text { terceirizados em cerca de } 4.939 \text { processos ( } 5.011 \text { processos em } 31 \text { de } \\
\text { dezembro de 2013) pelos quais são pleiteados equiparação salarial, horas } \\
\text { extras, adicional de periculosidade, complementação de aposentadoria entre } \\
\text { outros }\end{array}$ \\
\hline FIBRIA & $\begin{array}{l}\text { A Companhia tem aproximadamente } 5.612 \text { processos trabalhistas movidos por } \\
\text { ex-empregados, terceiros e sindicatos, cujos pleitos consistem em sua maioria } \\
\text { em pagamento de verbas rescisórias, adicionais por insalubridade e } \\
\text { periculosidade, horas extras, horas in itinere, indenizações por danos } \\
\text { materiais e morais, pagamento de diferenças de expurgos inflacionários sobre } \\
\text { multa de } 40 \% \text { do FGTS }\end{array}$ \\
\hline GOL & $\begin{array}{l}\text { Em } 31 \text { de dezembro de 2014, a Companhia e suas controladas são partes em } \\
28.738 \text { (8.195 trabalhistas e } 20.543 \text { cíveis) processos judiciais e } \\
\text { procedimentos administrativos. Os processos judiciais e procedimentos } \\
\text { administrativos são classificados em Operação (aqueles que decorrem do }\end{array}$ \\
\hline
\end{tabular}




\begin{tabular}{|c|c|c|c|c|c|c|c|}
\hline \multicolumn{8}{|c|}{ 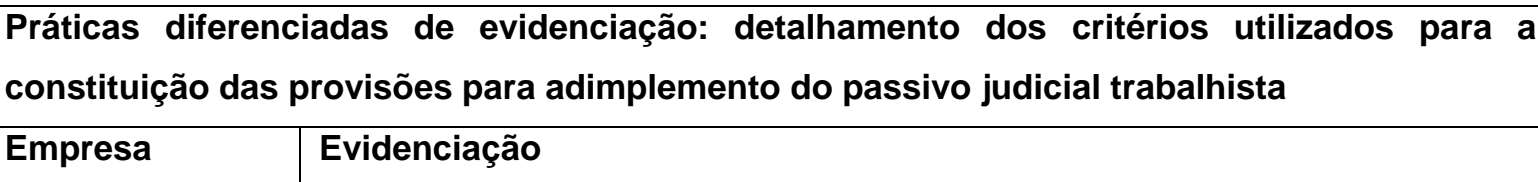 } \\
\hline & \multicolumn{7}{|c|}{$\begin{array}{l}\text { curso normal das operações da Companhia) e Sucessão (aqueles que } \\
\text { decorrem do pedido de reconhecimento de sucessão por obrigações da antiga } \\
\text { Varig S.A.). }\end{array}$} \\
\hline JBS & \multicolumn{7}{|c|}{$\begin{array}{l}\text { Em } 31 \text { de dezembro de } 2014 \text {, a Companhia era parte em } 12.994 \text { ações de } \\
\text { natureza trabalhista e acidentes de trabalho, envolvendo o valor total em } \\
\text { discussão de } \mathrm{R} \$ 1.964 .220 \text {. }\end{array}$} \\
\hline \multirow[t]{10}{*}{ SÃO MARTINHO } & \multicolumn{2}{|l|}{ Consolidado } & \multicolumn{5}{|r|}{ Instância } \\
\hline & Natureza & $\begin{array}{r}\text { № de } \\
\text { processos }\end{array}$ & $\begin{aligned} \text { Adminis- } \\
\text { trativa }\end{aligned}$ & \begin{tabular}{|r|}
19 Instância \\
judicial
\end{tabular} & $\begin{array}{c}\text { Tribunal } \\
\text { inferior }\end{array}$ & $\begin{array}{l}\text { Tribunal } \\
\text { superior }\end{array}$ & Total \\
\hline & $\begin{array}{l}\text { Ambientais } \\
\text { Civeis }\end{array}$ & & & 1.942 & 267 & - & \\
\hline & Indenizatórias & 22 & - & 7.084 & 117 & 32 & 7.233 \\
\hline & Revisäo de contratos & 11 & - & 235 & - & & 235 \\
\hline & $\begin{array}{l}\text { Retificação de área e registro imobiliário } \\
\text { Alvarás para obtenção de licença de }\end{array}$ & 1 & - & - & - & - & - \\
\hline & pesquisa minerária & 5 & - & - & - & - & - \\
\hline & $\begin{array}{l}\text { Outros processos civeis } \\
\text { Trabalhistas }\end{array}$ & 12 & - & 745 & - & - & 745 \\
\hline & Auto de Infração & 12 & 37 & - & - & - & 37 \\
\hline & & 86 & 568 & 10.006 & 384 & & 10.990 \\
\hline TIM & \multicolumn{7}{|c|}{$\begin{array}{l}\text { Do total de } 17.534 \text { reclamações trabalhistas em } 31 \text { de dezembro de } 2014 \\
\text { (13.577 em } 31 \text { de dezembro de 2013), movidas contra a Companhia e suas } \\
\text { controladas, a maioria refere-se a demandas que envolvem ex-empregados de } \\
\text { prestadores de serviços. }\end{array}$} \\
\hline
\end{tabular}

Quadro 6 - Práticas diferenciadas de evidenciação: detalhamento dos critérios utilizados para a constituição das provisões para adimplemento do passivo judicial trabalhista

O primeiro destaque a ser feito diz respeito à São Martinho que, inobstante ter divulgado a quantidade de ações por área (ambiental, cível e trabalhista), inclusive com as respectivas fases processuais, só o fez em relação às ações com perda possível. Quadro similar não foi apresentado para as ações com perda provável.

Fibria, Eletropaullo, Gol, JBS e TIM indicam as quantidades totais de ações em andamento. Braskem informou apenas a quantidade de ações que ensejou a realização de provisões. E, a CESP indica a quantidade de ações com estimativa de perda provável e de perda possível.

Aqui, o formato apresentado pela São Martinho é o que melhor elucida a situação quantitativa das ações, podendo (para melhoria da informação) ser divido em 
quantidade de ações totais, ações com perda provável e ações com perda possível.

\subsubsection{Cronograma de pagamentos}

$\mathrm{Na}$ análise de fluxo de caixa, conhecer os momentos em que os desembolsos serão efetivados é essencial para que o modelo possa ser construído e analisado. Assim, simplesmente conhecer os valores provisionados (por seus valores totais) pode não ser suficiente para que as análises financeiras possam ser efetuadas.

É necessário, então, que se conheça o cronograma dos pagamentos estimados para o passivo judicial trabalhista. E, para tanto, inobstante as dificuldades oriundas do tempo de tramitação de cada feito, que é variável de ação para ação, pode-se, na evidenciação, indicar as fases processuais em que as ações se encontram.

A partir do conhecimento dessas fases processuais pode-se estimar o momento em que os desembolsos serão efetuados, o que se materializa com a consulta aos dados estatísticos do Tribunal Superior do Trabalho, alusivos ao tempo de tramitação das ações trabalhistas em cada esfera judicial.

Então, sabendo-se que é possível a apresentação de cronograma de desembolsos, ainda que sujeito à variações, passou-se ao exame das demonstrações financeiras de modo a verificar se as companhias apresentaram tal informação.

Das 40 companhias analisadas tão somente 4 (10\% do total) indicam alguma forma de cronograma de desembolso. As demais 36 companhias são silentes em relação a tal aspecto.

$\mathrm{E}$, há caso de companhia que, expressamente, declara não ter condição de apresentar cronograma de desembolso. Nesse caso, a CEMIG que, assim se posicionou: 
A Administração da Companhia, tendo em vista os prazos e a dinâmica dos sistemas judiciário, tributário e regulatório, acredita não ser praticável fornecer informações úteis aos usuários destas informações contábeis a respeito do momento de eventuais saídas de caixa, bem como de qualquer possibilidade de reembolsos.

Com relação às companhias que, de alguma forma, evidenciaram o cronograma (ou informação nesse sentido) de desembolso, as informações foram expressas nos moldes sintetizados no quadro 7 , apresentado a seguir:






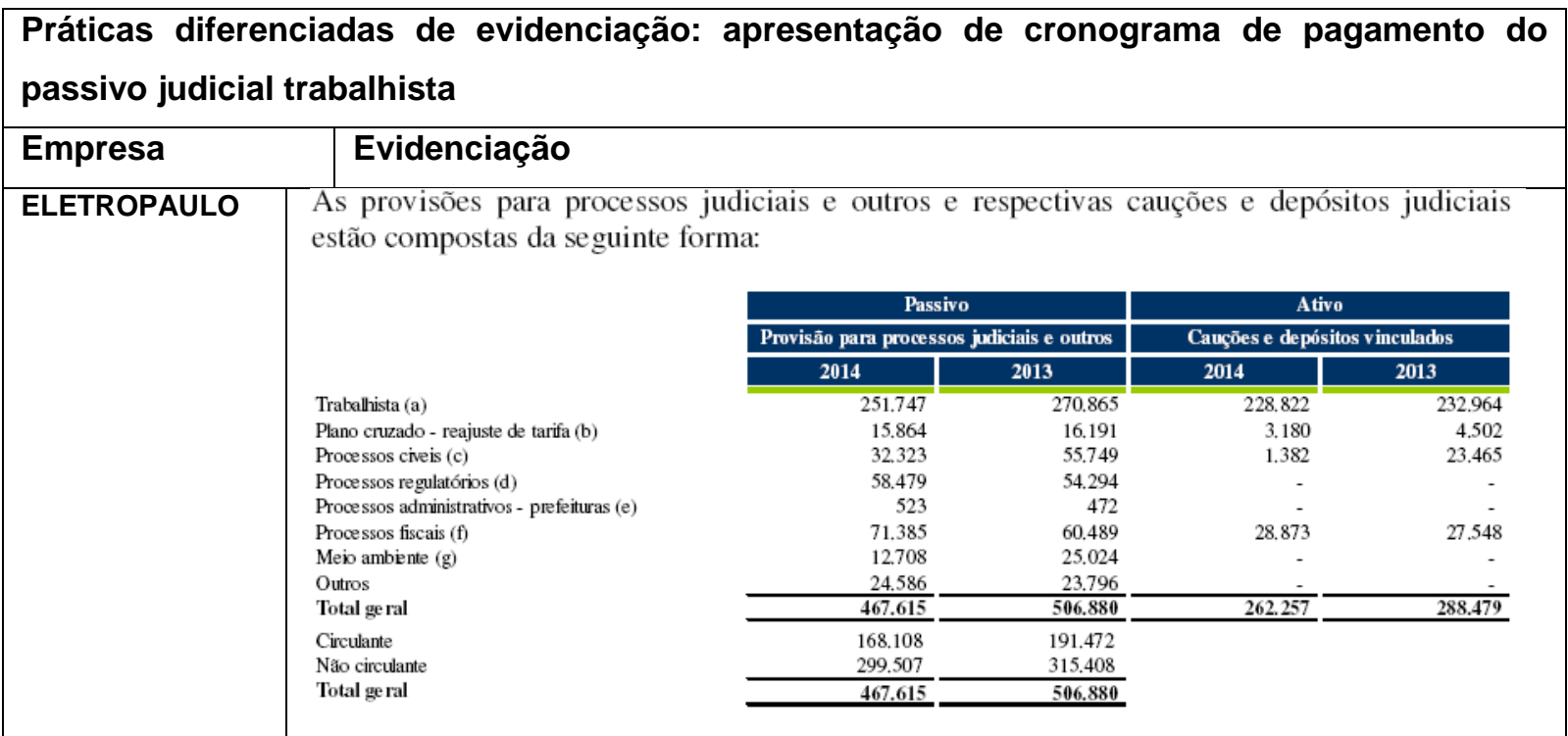

Quadro 7 - Práticas diferenciadas de evidenciação: apresentação de cronograma de pagamento do passivo judicial trabalhista

A AES SUL e a AES Eletropaulo, inobstante não apresentarem, exatamente, um cronograma, segregaram suas provisões em circulante e não circulante, o que permite, ao menos aferir quais são as saídas de caixa estimadas para o exercício seguinte.

O Banco do Brasil optou por apresentar cronograma em formato macro, com divisões de 5 em 5 anos. E, se esse cronograma não é o mais completo, ao menos sinaliza a existência de controles e de programação de tais ocorrências nas saídas de caixa.

No caso da Braskem, não se apresentou, efetivamente, um cronograma, mas há menção ao tempo estimado para o encerramento das ações em curso (5 anos).

A segregação das provisões em Circulante e Não Circulante, assim, não deveria se tratar de uma faculdade, mas de imposição eis que a dinâmica processual e a quantidade de ações em andamento para as companhias examinadas indica que o fluxo de pagamento de passivo judicial trabalhista é contínuo ao longo dos exercícios sociais, não se tratando de eventos esporádicos. 
E, em seguida, conciliando as informações disponibilizadas pelo TST com as particularidades de cada companhia, poder-se ia apresentar cronograma de desembolsos estimados, ainda que pelo prazo de 5 anos.

\subsection{Outras práticas de evidenciação}

Verificou-se, ainda, práticas de evidenciação que fogem aos parâmetros delineados como próximos da ideia de valor justo e de completude da informação.

Exemplo de tal situação ocorre com a Mahle que evidencia as provisões trabalhistas em conjunto com as provisões cíveis, não atribuindo, pois, maior importância a essa matéria. A evidenciação dessa companhia, no particular, foi efetuada do seguinte modo:

\begin{tabular}{|c|c|c|c|c|c|}
\hline & \multicolumn{5}{|c|}{ Consolidado } \\
\hline & $\begin{array}{c}\text { Cíveis e } \\
\text { trabalhista }\end{array}$ & Tributárias & $\begin{array}{c}\text { Passivo } \\
\text { ambiental }\end{array}$ & $\begin{array}{l}\text { Depósitos } \\
\text { judiciais }\end{array}$ & Total \\
\hline Saldo em $1^{\circ}$ de janeiro de 2013 & 124.238 & 52.629 & 9.218 & $(27.664)$ & 158.421 \\
\hline Adiçōes & 51.643 & 8.672 & 1.198 & $(10.746)$ & 50.767 \\
\hline Atualizações & 16.231 & 3.319 & - & (988) & 18.562 \\
\hline Baixa por utilização & $(7.122)$ & $(11.959)$ & $(1.344)$ & 772 & (19.653) \\
\hline Baixa por reversão & $(35.821)$ & $(22.052)$ & (35) & 1.959 & (55.949) \\
\hline Transferência & - & - & - & 1.930 & 1.930 \\
\hline Variação Cambial & (103) & - & (10) & - & (113) \\
\hline Saldo em 31 de deze mbro de 2013 & 149.066 & 30.609 & 9.027 & $(34.737)$ & 153.965 \\
\hline Adições & 59.901 & 19.805 & 430 & $(10.211)$ & 69.925 \\
\hline Atualizações & 21.040 & 2.119 & - & $(2.196)$ & 20.963 \\
\hline Baixa por utilização & (7.829) & - & $(1.645)$ & 728 & $(8.746)$ \\
\hline Baixa por reversão & $(23.167)$ & $(21.703)$ & - & 513 & (44.357) \\
\hline Transferência & - & - & - & 153 & 153 \\
\hline Variação Cambial & (117) & - & (16) & - & (133) \\
\hline Saldo em 31 de deze mbro de 2014 & 198.894 & 30.830 & 7.796 & $(45.750)$ & 191.770 \\
\hline
\end{tabular}

De se observar que o passivo ambiental, que representa menos de $4 \%$ das provisões cíveis e trabalhistas foi indicado de modo apartado, o que pode sugerir que a companhia outorga maior importância a esse tema. 
Outra boa prática constatada é a evidenciação das razões de aumento nos valores provisionados e, nesse sentido, está a CEMIG que apresenta a justificativa e detalha a situação da ação trabalhista mais importante em seu passivo. Assim:

O aumento no valor da contingência deve-se, dentre outros fatores, ao maior volume de ações movidas por ex-empregados, decorrente dos desligamentos realizados nos últimos anos, bem como ao maior volume de ações onde se discute a periculosidade sobre a remuneração, em função de novas teses que surgiram após alterações legislativas recentes.

Adicionalmente às questões descritas acima, a Companhia é parte em dissídio coletivo ajuizado por entidades representativas dos seus empregados, que visa o estabelecimento de normas e condições de trabalho para reger os contratos de trabalho no período de 01 de novembro de 2012 a 31 de outubro de 2013, cuja pauta de reivindicações trazia diversos assuntos, dentre eles a recomposição de perdas salariais, aumento real, piso salarial e reajuste das cláusulas econômicas. Em 04 de julho de 2013, foi publicado acórdão do Tribunal Regional do Trabalho (TRT) que manteve as cláusulas já existentes nos acordos coletivos anteriores, sem acrescentar nova obrigação à Companhia. Em 13 de outubro de 2014, foi publicada, pelo Tribunal Superior do Trabalho (TST), decisão em sede de Recurso Ordinário, para dar provimento ao recurso de uma entidade sindical, concedendo 3\% de aumento real aos empregados a título de produtividade. A Companhia apresentou Embargos de Declaração à seção especializada em dissídios coletivos do TST, a qual negou-lhe provimento em 15 de dezembro de 2014. Em 31 de dezembro de 2014, o valor envolvido nesta ação é de, aproximadamente, $\mathrm{R} \$ 127.411$, que está devidamente registrado, tendo em vista a atual fase processual, que motivou a reavaliação da probabilidade de perda, por parte de nossos assessores jurídicos, de possível para provável.

Considerando que a prática da terceirização é recorrente e que implica em riscos de responsabilização do tomador (solidária ou subsidiária), considerou-se como boa prática o procedimento da Light, em segregar as provisões alusivas aos seus empregados e aos terceirizados, do seguinte modo:

\begin{tabular}{|lrr|}
\hline & \multicolumn{1}{c|}{ Valor Provisionado (Perda Provável) } \\
\cline { 2 - 3 } & $\mathbf{3 1 . 1 2 . 2 0 1 4}$ & $\mathbf{3 1 . 1 2 . 2 0 1 3}$ \\
\hline Funcionários próprios & 96.974 & 102.342 \\
Funcionários terceirizados & 30.947 & 31.041 \\
\hline TOTAL & $\mathbf{1 2 7 . 9 2 1}$ & $\mathbf{1 3 3 . 3 8 3}$ \\
\hline
\end{tabular}


Outro destaque a ser efetuado diz respeito ao fato da Ol ter evidenciado, em suas Notas Explicativas, a composição do saldo provisionado para pagamento do passivo judicial trabalhista, segregado verba a verba, do seguinte modo:

\begin{tabular}{|c|c|c|c|c|c|}
\hline \multicolumn{6}{|c|}{$\begin{array}{l}\text { 21. PROVISÕES } \\
\text { Composição do saldo }\end{array}$} \\
\hline & \multirow[b]{2}{*}{ Natureza } & \multicolumn{2}{|c|}{ CONTROLADORA } & \multicolumn{2}{|c|}{ CONSOLIDADO } \\
\hline & & 2014 & 2013 & 2014 & 2013 \\
\hline & Trabalhista & & & & \\
\hline (i) & Horas extras & 258.072 & 246.841 & 471.506 & 474.910 \\
\hline (ii) & Indenizações & 71.460 & 73.511 & 152.113 & 150.612 \\
\hline (iii) & Adicionais diversos & 56.054 & 57.145 & 131.963 & 128.765 \\
\hline (iv) & Estabilidade / Reintegração & 73.958 & 74.632 & 126.070 & 120.863 \\
\hline (v) & Complemento de aposentadoria & 54.080 & 43.363 & 83.417 & 75.048 \\
\hline (vi) & Diferenças salariais & 31.719 & 33.668 & 52.852 & 56.997 \\
\hline (vii) & Honorários advocatícios/periciais & 17.891 & 20.439 & 29.382 & 30.969 \\
\hline (viii) & Verbas rescisórias & 6.810 & 8.428 & 20.235 & 24.945 \\
\hline (ix) & Multas trabalhistas & 3.981 & 4.201 & 15.562 & 16.758 \\
\hline$(\mathrm{x})$ & FGTS & 5.822 & 6.345 & 9.359 & 10.723 \\
\hline (xi) & Vínculo empregatício & 249 & 380 & 5.717 & 5.467 \\
\hline (xii) & Subsidiariedade & 850 & 1.262 & 1.581 & 2.292 \\
\hline \multirow[t]{3}{*}{ (xiii) } & Demais ações & 31.990 & 26.233 & 55.267 & 43.925 \\
\hline & Total & 612.936 & 596.448 & 1.155 .024 & 1.142 .274 \\
\hline & Tributária & & & & \\
\hline (i) & ICMS & 92.292 & 124.594 & 363.025 & 361.540 \\
\hline (ii) & FUST / FUNTTEL & & & & 147.350 \\
\hline (iii) & ISS & 536 & 1.629 & 71.666 & 67.350 \\
\hline (iv) & ILL & & & 20.691 & 19.998 \\
\hline$(\mathrm{v})$ & $\begin{array}{l}\text { INSS (responsabilidade solidária, } \\
\text { honorários e verbas indenizatórias) }\end{array}$ & 3.634 & 3.024 & 31.735 & 12.462 \\
\hline \multirow[t]{4}{*}{ (vi) } & Demais ações & 2.360 & 1.584 & 45.504 & 31.672 \\
\hline & Total & 98.822 & 130.831 & 532.621 & 640.372 \\
\hline & & & & & \\
\hline & Cível & & & & \\
\hline (i) & Societário & 1.549 .525 & 2.062 .709 & 1.549 .525 & 2.062 .709 \\
\hline (ii) & Estimativas ANATEL & 222.308 & 210.118 & 597.437 & 557.960 \\
\hline (iii) & Multas ANATEL & 106.592 & 96.572 & 506.726 & 487.548 \\
\hline (iv) & Juizado Especial & 148.122 & 48.720 & 282.209 & 137.859 \\
\hline \multirow[t]{6}{*}{ (v) } & Demais ações & 203.767 & 286.354 & 508.226 & 587.595 \\
\hline & Total & 2.230 .314 & 2.704 .473 & 3.444 .123 & 3.833 .671 \\
\hline & & & & & \\
\hline & Total das provisões & 2.942 .072 & 3.431 .752 & 5.131 .768 & 5.616 .317 \\
\hline & Circulante & 637.244 & 770.294 & 1.058 .521 & 1.223 .526 \\
\hline & Não circulante & 2.304 .828 & 2.661 .458 & 4.073 .247 & 4.392 .791 \\
\hline
\end{tabular}

Conforme estabelecido pelas respectivas legislações, as provisões para perdas em processos judiciais são mensalmente atualizadas monetariamente.

Esse tipo de informação, se divulgada com habitualidade permite ao usuário aferir a origem do passivo e verificar se algum ato de gestão está sendo praticado para mitigar os riscos. Pode-se, por exemplo, no caso da Ol verificar que o passivo judicial trabalhista é fortemente impactado por pleitos de horas extras e de pedidos 
de reintegração e pagamento de salários do período de afastamento.

Para esses dois casos os usuários poderiam questionar as práticas adotadas em relação à jornada de trabalho e à eventual violação de garantias de emprego (legais e normativas).

\subsection{Consolidação das análises}

As provisões para pagamento de passivo judicial trabalhista correspondem, em média, a $42,6 \%$ do total provisionado. E, tais provisões representam o valor médio de $36,9 \%$ dos saldos em caixa das companhias analisadas.

A relevância de tais provisões é corroborada pelo fato de corresponderem a 23,0\% (em média) do CCL e a 11,1\% do EBITDA, daí porque a correta mensuração é importante para a gestão do fluxo de caixa e para mitigar riscos financeiros.

Das análises promovidas não se constatou a efetiva aplicação dos preceitos do Direito Natural nas Notas Explicativas das demonstrações financeiras das companhias analisadas, as quais caracterizam-se pela indicação das informações mínimas contidas no CPC 25.

Os casos de boas práticas (maior alinhamento com o Direito Natural) são pontuais e compreendem a indicação da quantidade de ações em andamento, expectativa de desembolso (cronograma), detalhamento quanto à origem do passivo judicial trabalhista e informação quanto ao critério utilizado para a mensuração da provisão alusiva a cada ação.

Nenhuma companhia analisada, contudo, apresenta todos os requisitos supra, o que impede caracterizar os valores provisionados como justos.

Considerando, contudo, que, ainda que pontualmente, as companhias conseguem apresentar diferenciais positivos na evidenciação, tem-se que é possível alinhar essas boas práticas de modo a criar um padrão de evidenciação alinhado com os 
preceitos do Direito Natural, de modo a aproximar-se do valor justo provisionado.

Nesse sentido, destacam-se:

a) detalhamento da origem do passivo judicial trabalhista, como promovido pela OI e pela TIM;

b) descrição dos critérios utilizados para mensuração das provisões, nos moldes apresentados pelo Bradesco, pelo Banco Pan e pela $\mathrm{Ol}$;

c) indicação da quantidade de ações em andamento (provisionadas e não provisionadas), como apresentado pela São Martinho;

d) apresentação de cronograma de desembolsos, tal qual o do Banco do Brasil, porém, com intervalos menores (circulante e não circulante: 2 anos, 5 anos, 10 anos ou mais);

e) segregação das provisões em relação aos empregados próprios e aos terceirizados, como efetuado pela Light, para que se possa verificar o aspecto da responsabilização subsidiária ou solidária, oriunda dos efeitos da terceirização;

f) detalhamento da composição do saldo provisionado, por verba trabalhista, tal qual apresentado pela OI.

Essas boas práticas, à evidência, não são exaustivas mas, se apresentadas em conjunto, poderão sustentar que o valor provisionado tem alinhamento com 0 conceito de fair value. 


\section{CONSIDERAÇÕES FINAIS}

O Passivo Judicial Trabalhista, pelo aperfeiçoamento dos mecanismos processuais e pela necessidade de celeridade na tramitação, merece destaque no tratamento, sobretudo por conta das medidas de constrição eletrônica de recursos financeiros das empresas, como, é o caso da penhora eletrônica, por meio do BACEN JUD.

Gerenciar esses passivos de modo adequado pode evitar dificuldades adicionais em relação ao fluxo de caixa e aos índices de liquidez da empresa, daí porque é necessário evidenciar, de modo adequado, os riscos envolvidos na seara judicial trabalhista.

As disposições contábeis alusivas à evidenciação estabelecem parâmetros mínimos que devem ser observados pelas entidades para o atendimento às necessidades informacionais dos stakeholders, sendo que o Direito - e, em especial, o Direito Natural - amplia esse parâmetro, mencionando que o valor, para ser considerado como justo, não pode estar submetido a limites de normas oriundas do direito positivo.

Os benefícios do gerenciamento do passivo judicial trabalhista, contudo, não se resumem aos riscos financeiros, porque, o conhecimento efetivo da situação das ações judiciais trabalhistas, em relação às fases processuais, riscos estimados para aquele momento e expectativa de desembolso pode gerar oportunidades no caixa, seja pela efetivação de investimentos (porque os desembolsos judiciais estão no longo prazo) ou pela adoção de políticas conciliatórias, reduzindo a quantidade de ações em andamento.

Por essa razão, cuidar do reconhecimento e da mensuração dos passivos, observando cada momento da tramitação processual - apesar de mais trabalhoso em um primeiro momento - pode gerar oportunidades aos usuários internos. E, bem assim, tais atos comportam evidenciação aos usuários externos. 
Da análise promovida com as 40 empresas listadas nos segmentos Nível 1, Nível 2 e Novo Mercado de Governança Corporativa da BM\&FBovespa, incluídas no ranking dos maiores litigantes do TST, verificou-se que as determinações contábeis (CPC 25) tem sido observados pelas referidas empresas, em sua forma menos ampla e que, de outra parte, os preceitos do direito natural não tem sido observados, o que impede reconhecer os valores provisionados como justos.

Os desembolsos oriundos de passivo judicial trabalhista podem gerar riscos financeiros para as companhias mediante comprometimento do fluxo de caixa e, em termos médios, correspondem a:

- $42,6 \%$ do total provisionado;

- $36,9 \%$ dos saldos de caixa;

- $23,0 \%$ do CCL;

- $11,1 \%$ do EBITDA.

Recomenda-se a ampliação dos itens evidenciados em relação ao passivo judicial trabalhista de modo a aproximar as provisões ao Direito Natural e ao conceito de fair value, nos termos indicados no item 4.4. e com as variáveis lá apontadas.

Nenhuma das companhias, isoladamente considerada, apresentou boas práticas para todos os itens examinados. Contudo, foi possível verificar que há condição técnica e material para o aprimoramento das notas explicativas eis que as companhias - ainda que pontualmente - registram aspectos positivos na evidenciação, dos quais merecem destaque:

a) detalhamento da origem do passivo judicial trabalhista, como promovido pela Ol e pela TIM;

b) descrição dos critérios utilizados para mensuração das provisões, nos moldes apresentados pelo Bradesco, pelo Banco Pan e pela Ol;

c) indicação da quantidade de ações em andamento (provisionadas e não 
provisionadas), como apresentado pela São Martinho;

d) apresentação de cronograma de desembolsos, tal qual o do Banco do Brasil, porém, com intervalos menores (circulante e não circulante: 2 anos, 5 anos, 10 anos ou mais);

e) segregação das provisões em relação aos empregados próprios e aos terceirizados, como efetuado pela Light, para que se possa verificar o aspecto da responsabilização subsidiária ou solidária, oriunda dos efeitos da terceirização;

f) detalhamento da composição do saldo provisionado, por verba trabalhista, tal qual apresentado pela OI.

O fato é que revelou-se que há condição técnica para a melhoria do processo de reconhecimento, mensuração e evidenciação do passivo judicial trabalhista, cabendo, agora, difundir as boas práticas e, quiçá, torná-las compulsórias.

A ausência, em especial do cronograma estimado de desembolso implica que as companhias tendam (e assim procedem, na maioria) a classificar as provisões no longo prazo. Contudo, tal prática não se mostra adequada eis que há, ao final de cada período, ações que serão adimplidas no exercício seguinte (curto prazo) e, sem a indicação dos valores correspondentes há sujeição a erros de análise de tais demonstrações, inclusive em relação aos índices de liquidez.

A ausência de informações qualitativas (origem do passivo e critérios de mensuração) impedem que seja efetuada análise de atos de gestão alusivos à mitigação dos riscos de novas ações e, também, impedem que se possa atestar se os valores foram apurados em conformidade com o estágio atual de cada ação. 


\section{REFERÊNCIAS}

ALMEIDA, José Elias Feres de. Qualidade da informação contábil em ambientes competitivos. 2010. Tese (Doutorado em Controladoria e Contabilidade: Contabilidade) - Faculdade de Economia, Administração e Contabilidade, Universidade de São Paulo, São Paulo, 2010. Disponível em: <http://www.teses.usp.br/teses/disponiveis/12/12136/tde-29112010-182706/>. Acesso em: 2014-03-28

ALMEIDA, Maria Goreth Miranda; EL HAJJ, Zaina Said. Mensuração e Avaliação do Ativo: uma revisão conceitual e uma abordagem do Goodwill e do ativo intelectual. Cad. estud., São Paulo, n. 16, Dec. 1997 . Disponível em <http://www.scielo.br/scielo.php?script=sci_arttext\&pid=S1413-

92511997000300005\&lng=en\&nrm=iso >. Acesso em 29 Apr. 2014.

ANTUNES, J. ; ANTUNES, G. M. B. ; PENTEADO, I. M. . A Convergência Contábil Brasileira e a Adoção das Normas Internacionais de Contabilidade: O IFRS-1. In: X SEMEAD - Seminários em Administração - FEA-USP, 2007, São Paulo. X SEMEAD - Seminários em Administração - FEA-USP, 2007.

BARROS, Alberto Ribeiro G. de. Direito natural e propriedade em Jean Bodin. Trans/Form/Ação, Marília , v. 29, n. 1, 2006 . Disponível em <http://www.scielo.br/scielo.php?script=sci_arttext\&pid=S010131732006000100002\&lng=en\&nrm=iso>. Acesso em 28 Abr. 2014.

BERNSTEIN, Peter L. Desafio dos deuses: a fascinante história do risco. Rio de Janeiro: Campus, 1997.

BM\&FBOVESPA. Empresas listadas: Novo Mercado. Disponível em http://www.bmfbovespa.com.br/cias-listadas/empresaslistadas/BuscaEmpresaListada.aspx?ldioma=pt-br. Acesso em 29 Abr. 2014

BRASIL. Banco Central do Brasil. Perguntas Freqüentes do Bacen Jud 2.0. Brasília: 2010. Disponível em http://www.bcb.gov.br/?BCJ2FAQ. Acesso em 10 ago 2011. 
Brasília, DF

Constituição (1988). Constituição da República Federativa do Brasil.

. Lei $\mathrm{n}^{\circ}$ 8.177, de $1^{\circ}$ de março de 1991. Estabelece regras para a desindexação da economia e dá outras providências. Brasília, DF

- Tribunal Superior do Trabalho. Consolidação dos provimentos da Corregedoria Geral da Justiça do Trabalho. Brasília: 2009.

. Tribunal Superior do Trabalho. Petrobras perde audiência por causa de congestionamento de trânsito e Turma mantém revelia. Brasília: 2013. Documento eletrônico disponível em http://www.tst.jus.br/noticias/lasset_publisher/89Dk/content/petrobras-perde-audiencia-por-causa-decongestionamento-de-transito-e-turma-mantem-revelia Acesso em 12 jan 2016.

. Tribunal Superior do Trabalho. Prazos. Brasília: 2015. Documento eletrônico disponível em http://www.tst.jus.br/prazos Acesso em 12 jan 2016.

- Tribunal Superior do Trabalho. Ranking de partes. Brasília: 2015. Documento eletrônico disponível em http://www.tst.jus.br/ranking-de-partes Acesso em 12 jan 2016.

CARRION, Valentin. Comentários à consolidação das leis do trabalho. $31^{\mathrm{a}}$ ed. Atual. por Eduardo Carrion. São Paulo: Saraiva, 2006.

COMISSÃO DE VALORES MOBILIÁRIOS. Deliberação CVM N489, de 03 de outubro de 2005. Aprova o Pronunciamento do IBRACON NPC No 22 sobre Provisões, Passivos, Contingências Passivas e Contingências Ativas. Brasília

COMITÊ DE PRONUNCIAMENTOS CONTÁBEIS. Aperfeiçoamento das Notas Explicativas nas Demonstrações Contábeis. Documento eletrônico disponível em http://www.cpc.org.br/FACPC/Comunicacao/Nossos-Destaques/Destaque?id=238 Acesso em 12 abr 2014. 
Pronunciamento técnico CPC 25 - Provisões, Passivos

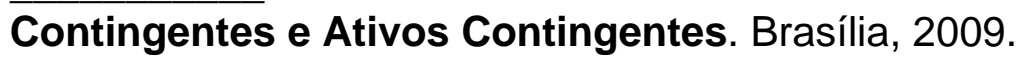

Pronunciamento técnico CPC 26 - Apresentação das demonstrações contábeis. Brasília, 2009

Pronunciamento Técnico CPC 46: Mensuração do Valor Justo.

Brasília, 2012.

CONSELHO FEDERAL DE CONTABILIDADE. Princípios fundamentais de contabilidade e normas brasileiras de contabilidade. $2^{\mathrm{a}}$. ed. Brasília: CFC, 2000.

COVELLO, Sergio Carlos. A obrigação natural : elementos para uma possível teoria. São Paulo: Leud, 1996. 190 p.

DANTAS, J. A.; ZENDERSKY, H. C.; NIYAMA, J. K. A dualidade entre os benefícios do disclosure e a relutância das organizações em aumentar o grau de evidenciação. In: ENANPAD, 28., 2004, Curitiba. Anais... Rio de Janeiro: ANPAD, 2004. CD-ROM.

DENCKER, A. F. M.; VIÁ, S. C. Pesquisa empírica em ciências humanas (com ênfase em comunicação). 2. ed. São Paulo: Futura, 2002.

DIAS FILHO, J. M. Características qualitativas da informação contábil: o problema da compreensibilidade à luz da teoria semiótica e da comunicação. 2001. 211 f. Dissertação (Mestrado em Ciências Contábeis) - Faculdade de Economia, Administração e Contabilidade, Universidade de São Paulo, São Paulo, 2001.

FERREIRA, Aracéli Cristina Sousa; SILVA, Márcia Castro; MORAIS, Macelly O.; SANTOS, Rodrigo Rodrigues. Análise integrada de indicadores em três dimensões: um caso de momentum aplicado a uma empresa brasileira. RIC Revista de Informação Contábil - ISSN 1982-3967 - Vol. 3, no 2, p. 99-112, AbrJun/2009 
FINANCIAL Accounting Standards Board (FASB). Statements of Financial Accounting Standards (SFAS) n. 107. Disclosures about fair value of financial instruments. Connecticut: FASB, 1991.

GLAUTIER, M. W. E.; UNDERSOWN, B. Acounting theory and pratice. $5^{\text {a }}$ th. ed. London: Pitman Publishing, 1994.

GOBERT, Michelle. Essai sur le rôle de l'obligation naturelle. Paris : Sirey, 1957. vii, 209 p..

GOLDRATT, Eliyahn M.; COX, Jeff. A meta. São Paulo: Imam, 1990.

GUERREIRO, Reinaldo. Modelo Conceitual de sistema de informação de gestão econômica: uma contribuição à teoria da comunicação da contabilidade, São Paulo, 1989. Tese (Doutorado) - FEA/USP

GUYAU, J M. Esbozos de una moral sin obligación ni sanción -- Buenos Aires : Ed Americalee, 1944.

HORKHEIMER, M. Eclipse da razão. tradução de Sebastião Uchoa Leite. Rio de Janeiro: Editorial Labor do Brasil, 1976.

IJIRI, Yuji. Theory of accounting measurement. Sarasota, Fla: American Accounting Association, 1975.

IBRACON. Instituto Brasileiro dos Auditores Independentes. Pronunciamento NPC $\mathbf{N}^{\circ} 22$ sobre Provisões, Passivos, Contingências Passivas e Contingências Ativas. São Paulo, 2005.

IUDÍCIBUS, Sérgio de. Teoria da Contabilidade. 6ª edição. São Paulo: Atlas, 2000.

IUDÍCIBUS, Sérgio de. Martins, Eliseu. Gelbcke, Ernesto Rubens. Manual de contabilidade das sociedades por ações: aplicável às demais sociedades. $6^{a}$ ed. São Paulo: Atlas: 2003. 
JENSEN M. e MECKLING, W. Theory of the firm: Managerial behavior, agency cost, and ownership structure. In: Journal os Financial Economics. 1976. p. 305360 .

KAM, Vernon. Accounting theory. $2^{\mathrm{a}}$ th. Ed. Canadá: John Wiley \& Sons, 1990.

LANZANA, Ana Paula. Relação entre disclosure e governança corporativa das empresas brasileiras. 2004. Dissertação (Mestrado em Administração) - Faculdade de Economia, Administração e Contabilidade, Universidade de São Paulo, São Paulo, $2004 . \quad$ Disponível em: <http://www.teses.usp.br/teses/disponiveis/12/12139/tde-11022005-094807/>. Acesso em: 2014-04-11

LIMA, João Batista Nast de. A relevância da informação contábil e o processo de convergência para as normas IFRS no Brasil. 2011. Tese (Doutorado em Controladoria e Contabilidade: Contabilidade) - Faculdade de Economia, Administração e Contabilidade, Universidade de São Paulo, São Paulo, 2011. Disponível em: <http://www.teses.usp.br/teses/disponiveis/12/12136/tde-24032011185955/>. Acesso em: 2014-04-18.

LOPES, Alexsandro Broedel. Uma análise crítica do arcabouço teórico do SFAS 133: Accounting for Derivative Instruments and Hedging Activities. Caderno de Estudos FIPECAFI. São Paulo, v. 11, n. 22, p.16-27, set./dez.1999.

2002.

A informação contábil e o mercado de capitais. São Paulo: Thomson,

MACHADO, Marcel Lopes. A natureza social dos créditos do trabalho e a incidência do IRRF nas execuções trabalhistas. Revista do Tribunal Regional do Trabalho da $3^{a}$ Região. Belo Horizonte, v.50, n.80, p.55-60, jul./dez.2009.

MACINTOSH, N. B.; BAKER, C. R. (2002). A literary theory perspective on accounting: Towards heteroglossic accounting reports. Accounting, Auditing \& Accountability Journal, 15(2), 184-222.

Disponível 
http://search.proquest.com/docview/211253411?accountid=34586. Acesso em 28 abr. 2014

MALHOTRA, N. K. Pesquisa de marketing: uma orientação aplicada. 3. ed. Porto Alegre: Bookman, 2001.

MATIAS. Alberto Borges. Finanças corporativas de curto prazo: a gestão do valor do capital de giro. São Paulo: Atlas, 2007.

MOISSET DE ESPANÉS, Luis. Obligaciones naturales y deberes morales. Buenos Aires : Zavalia, 1998. 377 p.

NICOLETTA, Costábile. Notas explicativas dos balanços ganharam tamanho e perderam transparência. Documento eletrônico disponível em http://www.cpc.org.br/FACPC/Comunicacao/Noticias/Noticia?id=235. Acesso em 25 fev 2014.

NIYAMA, Jorge Katsumi; GOMES, Amaro L. Oliveira. Contribuição ao aperfeiçoamento dos procedimentos de evidenciação contábil aplicáveis às demonstrações financeiras de bancos e instituições assemelhadas. Anais do XV Congresso Brasileiro de Contabilidade. Brasília: CFC, 1996.

PEREIRA, A. C et. Alli. A relevância do Passivo Oculto no "disclosure" da informação contábil. Revista Álvares Penteado. São Paulo. no 6 p. 107-118 junho/2001.

PONTE, Vera Maria Rodrigues; OLIVEIRA, Marcelle Colares. A prática da evidenciação de informações avançadas e não obrigatórias nas demonstrações contábeis das empresas brasileiras. Rev. contab. finanç., São Paulo , v. 15, n. 36, Dec. 2004 . Disponível em <http://www.scielo.br/scielo.php?script=sci_arttext\&pid=S1519-

$70772004000300001 \&$ Ing=en\&nrm=iso>. Acesso em 18 Apr. 2014.

PRESTES, Cristina. Análise de risco judicial é aleatória. Valor Econômico. São Paulo. Publicado em 6 de agosto de 2007. 
RIAHI-BELKAOUI, Ahmed. Accounting theory. Londres: Thomson, 2005.

RIBEIRO, Antonio de Cistolo; RIBEIRO, Maisa de Souza; WEFFORT, Elionor Farah Jreige. Provisões, contingências e o pronunciamento cpc 25: as percepções dos protagonistas envolvidos. Revista Universo Contábil, [S.I.], v. 9, n. 3, p. 38-54, set. 2013. ISSN 1809-3337. Disponível em: $<$ http://proxy.furb.br/ojs/index.php/universocontabil/article/view/3309>. Acesso em: 18 Abr. 2014.

SANTIN, Dirce Maria. Avanços e perspectivas da infometria e dos indicadores multidimensionais na análise de fluxos da informação e estruturas do conhecimento. Encontros Bibli: Revista Eletrônica de Biblioteconomia e Ciência da Informação, v. 16, n. 32, p. 107-122, 2011. ISSN 1518-2924. DOI: 10.5007/15182924.2011v16n32p107

SCHMIDT, P., SANTOS, José Luiz dos. Avaliação de ativos intangíveis. São Paulo: Atlas, 2002.

SCRIMNGER-CHRISTIAN, C., \& MUSVOTO, S. W.. The accounting concept of measurement and the thin line between representational measurement theory and the classical theory of measurement. The International Business \& Economics Research Journal, 10(5), 59-68. 2011 Disponível em http://search.proquest.com/docview/868711493?accountid=34586. Acesso em 28 abr 2014.

TEIXEIRA FILHO, Manoel Antonio. Execução no processo do trabalho. $6^{a}$ ed. rev. e atual. - São Paulo: LTR, 1998.

VELASCO, José Ignacio Cano Martínez de. La obligación natural. Barcelona: Bosch, 1990. $90 \mathrm{p}$.

XISTO, José Gustavo Rezende de. Matias, Alberto Borges (orient). Contribuição para o desenvolvimento de um modelo de sustentabilidade financeira de empresas. Dissertação (Mestrado em Administração de Organizações). Faculdade 
de Economia, Administração e Contabilidade de Ribeirão Preto. Universidade de São Paulo. Ribeirão Preto, 2007. 128 p.. 